\title{
"Home Sweet Away-From-Home?" Morgantown, West Virginia's Sunnyside Neighborhood as a Cultural Landscape
}

\author{
Pamela Yvonne Curtin
}

Follow this and additional works at: https://researchrepository.wvu.edu/etd

\section{Recommended Citation}

Curtin, Pamela Yvonne, "'Home Sweet Away-From-Home?" Morgantown, West Virginia's Sunnyside Neighborhood as a Cultural Landscape" (2017). Graduate Theses, Dissertations, and Problem Reports. 5422.

https://researchrepository.wvu.edu/etd/5422

This Thesis is protected by copyright and/or related rights. It has been brought to you by the The Research Repository @ WVU with permission from the rights-holder(s). You are free to use this Thesis in any way that is permitted by the copyright and related rights legislation that applies to your use. For other uses you must obtain permission from the rights-holder(s) directly, unless additional rights are indicated by a Creative Commons license in the record and/ or on the work itself. This Thesis has been accepted for inclusion in WVU Graduate Theses, Dissertations, and Problem Reports collection by an authorized administrator of The Research Repository @ WVU. For more information, please contact researchrepository@mail.wvu.edu. 


\title{
"Home Sweet Away-From-Home?" \\ Morgantown, West Virginia's Sunnyside Neighborhood as a Cultural Landscape
}

\author{
Pamela Yvonne Curtin
}

Thesis submitted to the

Eberly College of Arts and Sciences

at West Virginia University

in partial fulfillment of the requirements for the degree of

\author{
Master of Arts \\ in \\ History \\ Area of Emphasis in Public History
}

Melissa Bingmann, PhD., Chair

Ken Fones-Wolf, PhD.

Jenny Boulware

Department of History

Morgantown, West Virginia

2017

Keywords: Morgantown, West Virginia, Sunnyside, Cultural Landscapes, Neighborhoods, Identity, Revitalization, Student Culture, Student Housing, College Towns, Microhistory

Copyright 2017 Pamela Yvonne Curtin 


\section{ABSTRACT \\ "Home Sweet Away-From-Home?" \\ Morgantown, West Virginia's Sunnyside Neighborhood as a Cultural Landscape}

\section{Pamela Yvonne Curtin}

Sunnyside is a 130 -acre neighborhood bordering West Virginia University in Morgantown, West Virginia. Since the 1890s, it has been home to a variety of transient residents, including industrial workers, families, and individuals associated with the University. Beginning in the 1960s, Sunnyside transitioned into Morgantown's primary student neighborhood.

Students took up residence in old two- and three-story frame houses broken into smaller units; often, these houses lacked necessary upkeep, failed code standards, and indicated the neighborhood's broader deteriorating conditions. Furthermore, student parties in Sunnyside grew increasingly intense and reflected negatively on West Virginia University, labeled in the 1970s as a "party school." Recently, Sunnyside has been the target of significant revitalization efforts aimed at transforming its physical, social, and cultural constructions, which have stirred conversations about Sunnyside's past as well as its future.

Using contemporary revitalization as context, this study explores Sunnyside as a cultural landscape. Drawing from interdisciplinary sources, Sunnyside fits within historiographies of higher education, deindustrialization, local history, and public history, as well as sociological and geographical studies of college towns, party schools, and urban revitalization. The first chapter is a microhistory that examines select structures in Sunnyside; it traces the stories of people who lived and worked in these structures before they were demolished to make way for an eight-story apartment complex. The second chapter looks at off-campus housing in Morgantown in the midtwentieth century, analyzing student understandings of their relationships with town and gown communities and the quality of housing available. Lastly, the third chapter connects Sunnyside as a controversial student neighborhood and West Virginia University's party school image in the late twentieth century. Together, these studies reveal Sunnyside's diverse meanings and purposes. 


\section{Acknowledgments}

I extend deep appreciation to the committee members, Melissa Bingmann, Ken FonesWolf, and Jenny Boulware, who have guided this project from start to finish. Their expertise, insight, and open door policy have not only strengthened this project, but also my knowledge and skills as a historian.

I cannot overstate Jenny Boulware's dedication to preserving and interpreting Sunnyside's history, while enlightening students through the processes of historical inquiry. She and her students have laid an invaluable foundation for myself and future historians. I appreciate her inviting me to talk with her current Local History Research Methodology course and for joining me in Indianapolis to present our work at the Annual Meeting of the National Council on Public History.

I thank Elizabeth Fones-Wolf and fellow graduate students in the Writings Seminar on twentieth century history for taking the time to read drafts, provide feedback, and discuss Sunnyside's past, present, and future.

I am grateful for the staff and volunteers at the West Virginia and Regional History Center, West Virginia University Libraries, and Aull Center for Local History and Genealogical Research. Their assistance on a day-to-day basis is so appreciated, as is their larger mission of preserving and making accessible important historical collections.

As a writer, I thank the WVU English Department, especially Tom Sura and Sarah Morris, and the Eberly Writing Studio for their support and guidance. I am delighted I can call both Woodburn and Colson Halls home.

My colleagues in the WVU History Department are an important source of wisdom and encouragement. I thank everyone for their fellowship.

As always, I am grateful for the History Department at Saint Vincent College. I thank Tim Kelly for his constant support and vision for my potential and Karen Kehoe for sparking my passion for public history.

I send love and gratitude to my parents for instilling in me an appreciation for history and to my sister Kathrine for our trips to museums and historic sites around the world. 


\section{Table of Contents}

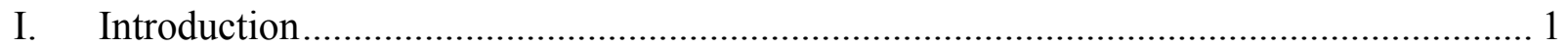

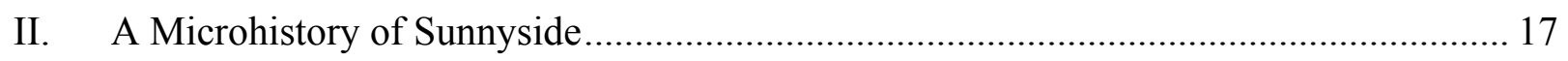

III. Students, the University, and In Loco Parentis in Off-Campus Housing........................ 50

IV. Sunnyside: A Landscape of Personalities and Problems ............................................. 88

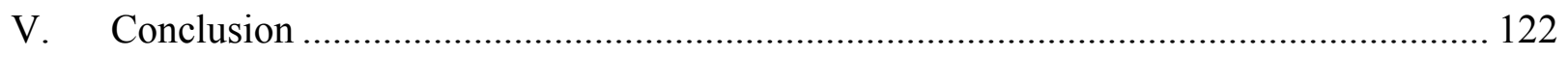

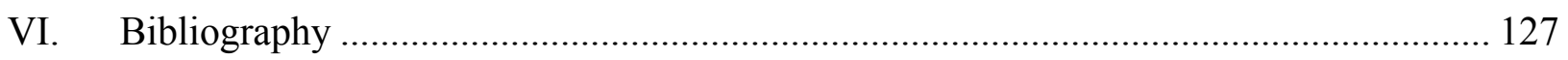

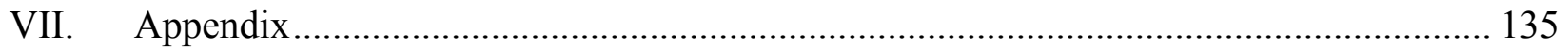




\section{INTRODUCTION}

"You can't take away the memories!" Janna Kuett, an undergraduate at West Virginia University, wrote on Twitter on April 4, 2013, the day Mutt's Sunnyside Pub, a favorite student hangout, was demolished in the Sunnyside neighborhood of Morgantown, West Virginia. ${ }^{1}$ Six months earlier, the modest three-story frame house converted into a tavern sold for $\$ 825,000$, a price that reflected not the value of the structure, but the value of the land. ${ }^{2}$ West Virginia University, in a public-private partnership with a local development group, purchased Mutt's, along with 39 neighboring buildings of similar construction and quality, to make way for a $\$ 70$ million residential and commercial complex within walking distance of the University's Downtown campus. ${ }^{3}$ The demolished structures, most of which were built in the late nineteenth and early twentieth centuries, architecturally characterized Sunnyside as a neighborhood once built for local industrial workers and their families. Yet for University students like Janna Kuett, the demolition signaled the end of a newer social and cultural era in Sunnyside. The loss of Mutt's, the last bar in Morgantown's most recognizable student neighborhood, meant that late nights, cheap alcohol, and free pool with friends would be history. In fewer than 140 characters, Kuett's exclamation on the permanence of memory captures a divisive contemporary issue: the future of Sunnyside and the role of its past.

Sunnyside, a 130-acre swath of hillside along the Monongahela River, has been home to groups of transient residents since the 1890s. The neighborhood thrived with Morgantown's

\footnotetext{
${ }^{1}$ Janna Kuett, Twitter post, April 4, 2013, 10:35am https://twitter.com/JKuett/status/319820395656138754

${ }^{2}$ Monongalia County, West Virginia, Deed Book 1468, p. 383; Mottie Pavone to Paradigm Development Group, LLC, October 26, 2012; Office of the Recorder of Deeds, City of Morgantown.

${ }^{3}$ University Relations/News, "WVU engages in public-private partnership to develop a $\$ 70$ million mixed use residential and retail complex in Sunnyside," WVU Today, Oct. 26, 2012, accessed April 24, 2017, http://wvutoday.wvu.edu/n/2012/10/26/wvu-engages-in-public-private-partnership-to-develop-a-70-million-mixeduse-residential-and-retail-complex-in-sunnyside.
} 
glass industry into the mid-twentieth century. The houses, two- or three-story frame structures with rooms spacious enough to accommodate numerous tenants, filled with industrial workers and their families. They also became home to students, who boarded with families while they pursued education at West Virginia University. Since the 1960s, as deindustrialization gradually drained Morgantown of its traditional worker population, undergraduate students claimed Sunnyside as their own. Most notably, the houses and streets pulsed with rambunctious student parties and dramatic couch burnings that could elicit nostalgic sighs or exasperated eye rolls, depending on the perspective. While students took visible ownership of the neighborhood, the nature of this ownership was symbolic and temporary. Students rented Sunnyside's houses for short periods of time, cycling through the University every four or so years. True legal ownership rested in the hands of landlords, and into the 2000s, increasingly with local organizations and West Virginia University. Concerned with the buildings' physical deterioration and issues with student behavior, these local stakeholders initiated plans to reimagine Sunnyside as an "urbane neighborhood known for its livability, convenience and character."

Today, these revitalization efforts are the subject of contentious debates surrounding student life, housing, and urban revitalization. Yet in a time when so much of the local community questions the neighborhood's future, Sunnyside also carries the weight of its past. Its dilapidated buildings and reputation for rowdy, and sometimes dangerous, student parties have shaped modern conceptions of the neighborhood's meanings and the direction new development should take. In a college town, housing is an "undeclared but unresolved civil war" between

\footnotetext{
${ }^{4}$ Environmental Planning and Design, LLC, Sunnyside Up: Comprehensive Revitalization Plan, Volume 1 (Morgantown, WV: Campus Neighborhoods Revitalization Corporation, Fall 2004), iii.
} 
students, universities, and citizens that deserves historical treatment. ${ }^{5}$ For some, Sunnyside is a place where student traditions represent the "WVU experience." For others, such traditions have marked WVU as one of the nation's most notorious party schools, diminishing the University's educational prestige and thwarting ongoing efforts to disprove West Virginia stereotypes.

As a graduate student at West Virginia University, I developed a sense of ownership not by living in Sunnyside, but by studying it. The History Department's Local History Research Methodology course, led by Jenny Boulware, introduced me to the neighborhood, a place I had heard to avoid while apartment hunting in Morgantown. I entered Sunnyside first through the archives, sifting through maps, newspapers, deeds, directories, census records, and photographs to piece together narratives of a place with no collections or formal recordkeeping. I collected interdisciplinary secondary sources that instilled broader significance in the neighborhood. Yet understanding Sunnyside, both past and present, also involves contemporary conversations; instructors, fellow student researchers, and community members provided varied and competing perspectives that demonstrate the multitude of Sunnyside's meanings. Lastly, as I watched entire blocks of Sunnyside vanish amid my short time as a Morgantown resident, I felt compelled to continue documenting Sunnyside's history. I walked the streets with a camera in hand and ideas in my head for how I could move forward after Local History Research Methodology came to a close. I knew that while I could not solve Sunnyside's problems, I could try to better understand their historical origins.

In this thesis, I argue Sunnyside's problems are not simply part of history, but are history. A nuanced understanding of this history can provide another voice to current conversations. Through its 120 years, Sunnyside has undergone different iterations as neighborhood

\footnotetext{
${ }^{5}$ Blake Gumprecht, The American College Town (Amherst: University of Massachusetts Amherst Press, 2008), 296.
} 
demographics have changed. Its physical structures, recycled by various people and for various purposes over the decades, have diverse stories to tell. Through these stories, it is clear Sunnyside's past has no singular narrative and its varying narratives can exist simultaneously. Furthermore, these narratives fit within broader issues the West Virginia University community has faced over the years, including student-university relationships, town-gown relationships, off-campus housing, shifts in higher education, and the party school image. While some portions of the thesis analyze Sunnyside's history from its founding, most focus on the 1960 s to the 1980s, the era in which Sunnyside earned its contemporary reputation as a blighted neighborhood filled with unruly undergraduates. By examining conceptions of place, this research reveals that students have felt a sense of ownership of Sunnyside, as well as the University and city of Morgantown. As the West Virginia University community grapples with Sunnyside's future, this thesis aims to shed light on social and cultural meanings of Sunnyside's recent past.

\section{Historiography}

Various historiographies inform this study, particularly in public history, the history of higher education, deindustrialization, revitalization, and local history. These works are supported by an interdisciplinary application of sociology and geography, which bring more understanding to the social and environmental processes in Sunnyside.

Sunnyside is shaped by an interplay of its people and its physical characteristics. A cultural landscape approach appreciates individual and collective perspectives and, subsequently, deepens Sunnyside's meanings. The National Park Service defines a cultural landscape as “a geographic area (including both cultural and natural resources and the wildlife or domestic 
animals therein), associated with a historic event, activity, or person or exhibiting other cultural or aesthetic values." ${ }^{\prime 6}$ The cultural landscape approach has grown increasingly popular in the public history field, inviting holistic and nonlinear approaches to historical interpretation and preservation. Cultural landscape works help situate Sunnyside within discussions of place, environment, and community. Dolores Hayden's formative approach to urban history in The Power of Place: Urban Landscapes as Public History (1995) infuses the traditional aesthetic qualities of a place with memory, identity, and culture. "Sense of place," she argues, is a "powerful source of memory" that encompasses and transcends physical surroundings. ${ }^{7}$ Essays in Public History and the Environment (2004), edited by Martin V. Melosi and Philip Scarpino, use environmental approaches as a "mode of thinking" that looks at history in "threedimensional terms." ${ }^{\prime 8}$ Similarly, Richard Longstreth's Cultural Landscapes: Balancing Nature and Heritage in Preservation Practice (2008) argues that the cultural landscape is not "simply comprising physical entities" but a "method of considering, analyzing, and evaluating place." 9 Applying this method to Sunnyside allows the social and cultural perspectives to be integrated into conversations of its "physical entities," which some community members see as practical obstacles to progress. In a time when Sunnyside's history wrestles with its future, the "sense of place" can be an insightful contribution to contemporary conversations.

As a cultural landscape, Sunnyside has physical, social, and cultural features distinct from other areas of Morgantown. However, neighborhoods like Sunnyside usually exist in

\footnotetext{
6 "Defining Landscape Terminology," Guidelines for the Treatment of Cultural Landscapes, National Park Service, Department of the Interior, accessed April 5, 2017, https://www.nps.gov/tps/standards/fourtreatments/landscape-guidelines/terminology.htm.

${ }^{7}$ Dolores Hayden, The Power of Place: Urban Landscapes as Public History (Cambridge: The MIT Press, 1997), 15-18.

${ }^{8}$ Martin V. Melosi and Philip Scarpino, Public History and the Environment (Malabar, FL: Krieger Publishing, 2004), ix-x.

${ }^{9}$ Richard Longstreth, Cultural Landscapes: Balancing Nature and Heritage in Preservation Practice (Minneapolis: University of Minnesota Press, 2008), 1.
} 
college towns, a phenomenon that geographer Blake Gumprecht analyzes in The American College Town (2013). As the first comprehensive study of its kind, Gumprecht defines an American college town as "any city where the college or university and the cultures it creates exert a dominant influence over the character of the town." ${ }^{10}$ He argues that universities do not exist in a "vacuum." As integral public spaces within the American landscape, they have physical, social, and cultural influences that "extend beyond the college grounds." ${ }^{11}$ Morgantown embodies distinguishing characteristics of an American college town: it is an isolated, educated, and cosmopolitan place in which at least $20 \%$ of the local population is comprised of four-year college students. These students are diverse and transient individuals who shape a town's social, cultural, political, economic, and commercial characteristics; in particular, a student population tends to drive up costs of living, rent apartments with high turnover, and live in group housing. ${ }^{12}$ In Morgantown, housing is an expensive endeavor, with the cost of living $14 \%$ higher than the national average as of $2014 .^{13}$

Gumprecht describes three segregated residential areas found in college towns: fraternity row, the faculty enclave, and the student ghetto. In Morgantown, Sunnyside is the archetypal student ghetto: a neighborhood of undergraduate tenants, usually unaffiliated with Greek life, located near the college campus. Born from housing shortages in the postwar era, the student ghetto is characterized by "dilapidated houses, couches on porches, cars parked on lawns, and bicycles chained to anything."14 This physical description reflects Cornell University's

\footnotetext{
${ }^{10}$ Gumprecht, The American College Town, 1.

${ }^{11}$ Ibid., xvi-xvii.

12 Ibid., 1-20.

${ }^{13}$ Katie Griffith, “The \$250,000 Question,” Morgantown Magazine, April 7, 2015, accessed April 24, 2017, http://www.morgantownmag.com/morgantown/April-May-2015/The-250000Question/index.php?cparticle $=1$ \& siarticle $=0 \#$ artanc.

${ }^{14}$ Gumprecht, The American College Town, 71-79, 86, 98-99. The term "ghetto," Gumprecht clarifies, is used in its traditional definition as "a neighborhood where a particular group lives in relative isolation from the rest
} of the population" (40). 
Collegetown, which Gumprecht profiles in his book, as well as Morgantown's Sunnyside. In contrast, a college town's fraternity row comprises larger and more architecturally impressive housing. Morgantown's Greek houses are clustered on the side of campus opposite of Sunnyside, leading up High Street's steep hill. Although different from one another in construction and population, both the student ghetto and fraternity row are notorious for parties. Separate from the bustle of campus and student activity is the faculty enclave, where professors and their families reside in elegant houses on quiet neighborhood streets. In Morgantown, this is best reflected in South Park, a historic district detached from downtown by Decker's Creek. Recognized for its architecture styles, South Park is comprised of post-Victorian Revivals, Gothics, Queen Anne's, and Bungalows, far more distinctive than Sunnyside's simple frame houses.

Sunnyside should be analyzed for its distinct character as a student ghetto as well as its situation within Morgantown. Flanking West Virginia University’s Downtown campus, Sunnyside is a highly visible and valuable space, which generates urgency for revitalization. Sunnyside is, therefore, what Jane Jacobs describes in her classic, The Death and Life of Great American Cities (1961), as a "border" that has powerful influence over the larger territory it neighbors. These borders, including neighborhoods near universities, are more vulnerable to blight. ${ }^{15}$ Because this study emphasizes cultural landscape more than political and economic forces, the "border" concept highlights Sunnyside's physical location as important to student tenants, University image, and revitalization efforts.

Because of Sunnyside's close ties to the West Virginia University community, I build on an invaluable foundation of works by professors and students. William T. Doherty, Jr. and Festus

\footnotetext{
15 Ibid., 74-78, 99-103; "South Park Historic District," National Register of Historic Places, Department of the Interior. 1990; Jane Jacobs, The Death and Life of Great American Cities (New York: Modern Library, 1961), 336-352.
} 
P. Summers's West Virginia University: Symbol of Unity in a Sectionalized State (1982) is the first comprehensive academic history of WVU. Penned by history professors, West Virginia University spans over 100 years of University contributions, triumphs, and struggles within a state rife with political, social, and economic divisions. Thirty years later, Ronald L. Lewis, a professor emeritus of Appalachian history, presented a "modern history" of the University with Aspiring to Greatness: West Virginia University Since World War II (2013). Lewis places West Virginia University within the history of higher education, which he categorizes into three broad eras: expansion in the postwar era, diversification from 1975 to the early 1990s, and commercialization from the 1990s into the twenty-first century. Lewis's work sets a precedent for the use of source material at home in the West Virginia and Regional History Center. I also follow Lewis's precedent in naming West Virginia University in this thesis; I will most often call West Virginia University "WVU" or "the University," for the sake of brevity. ${ }^{16}$

The WVU community has produced articles, theses, and dissertations that interpret local history in a variety of ways. C. Belmont Keeney's 2009 dissertation, "Soldiers and Stereotypes: Mountaineers, Cultural Identity, and World War II," explores the Appalachian mountaineer as a mythic figure, arguing that he is "one of the cornerstones of the conceptualization of Appalachia as a distinct and exceptional culture. ${ }^{17}$ Rosemary Hathaway, an English professor and folklorist, expanded on these ideas in her article, "From Hillbilly to Frontiersman: the Changing Nature of the WVU Mountaineer," which connects the varied iterations of the mountaineer stereotype with WVU's mascot. These histories inform conversations on WVU's unique problem with University image and stereotyping of its student body as uneducated and uncivilized. Lastly, Bob

\footnotetext{
${ }^{16}$ Ronald L. Lewis, Aspiring to Greatness: West Virginia University Since World War II (Morgantown, WV: West Virginia University Press, 2013), 1, xiv.

${ }^{17}$ C. Belmont Keeney, "Soldiers and Stereotypes: Mountaineers, Cultural Identity, and World War II," PhD Dissertation (West Virginia University, 2009), 2.
} 
Barnett's Hillside Fields: A History of Sports in West Virginia (2013) contributes to discussions of WVU athletics. As the home of Mountaineer Field for more than sixty years and the student parties that continue today, Sunnyside also changes in response to local sports. Additional discussions of sports are informed by Blake Gumprecht's chapter in The American College Town on stadium culture and Timothy Jon Curry, Kent Schwirian, and Rachael A. Woldoff's High Stakes: Big Time Sports and Downtown Redevelopment (2004).

Works on Morgantown and West Virginia history allow this college town to have a past beyond the context of contemporary Sunnyside and the University. Earl L. Core's five-volume The Monongalia Story: A Bicentennial History provides a year-by-year timeline of significant local events; volumes IV and V chronicle industrialization of the city and the increasing size and scope of WVU. As a local history study, this thesis also builds off broad research methods found in David E. Kyvig and Myron A. Marty's Nearby History: Exploring the Past Around You (2010). Ken Fones-Wolf’s Glass Towns: Industry, Labor and Political Economy in Appalachia, 1890-1930s informs Sunnyside's development as a neighborhood for local glassworkers. Although glassworkers and other industrial workers were transient like their academic neighbors, their social and cultural experiences were distinct from student life.

As Morgantown deindustrialized in the mid-twentieth century, secondary works interpret how cities and towns have struggled with change; among them are Jane Jacobs's The Death and Life of Great American Cities (1961), Barry Bluestone and Bennett Harrison's The Deindustrialization of America: Plant Closings, Community Abandonment, and the Dismantling of Basic Industry (1982), John A. Jakle and David Wilson's Derelict Landscapes: The Wasting of America's Built Environment (1992), Jefferson Cowie and Joseph Heathcott's edited volume, Beyond the Ruins: The Meanings of Deindustrialization (2003), and Alison Isenberg's 
Downtown America: A History of the Place and the People Who Made it (2004). In particular, Beyond the Ruins interprets urban revitalization and deindustrialization through the framework of "Anytown, USA," a sprawl of chain stores, restaurants, and cinemas that lack character and only make nostalgic, "commodified" mentions of history. ${ }^{18}$ A similar pattern has occurred in Sunnyside, where small businesses such as the Sunnyside Superette, in business for more than 75 years, closed when a Sheetz opened nearby.

Studentification, defined as the "as the displacement of local residents with younger more mobile populations of students" occurred in Sunnyside throughout the second half of the twentieth century. Most modern studies of studentification involve the displacement of lower class, ethnic communities with middle and upper class student populations. Considered a type of gentrification, the higher-quality housing associated with studentification breaks down traditional community structures. ${ }^{19}$ In Sunnyside, a form of studentification began occurring in the 1960s, as students replaced industrial workers and their families. Today, however, a new form of studentification is occurring; students are forced to leave their small rental houses to make way for large-scale mixed-use apartment complexes.

Larger trends in the history of higher education are visible at WVU. John R. Thelin's $A$ History of American Higher Education (2004) interprets social, political, and economic shifts in higher education on a national scale. His approach embraces the idea that colleges and universities are historical in nature, "heirs to various historical strands" that are formally

\footnotetext{
18 Jefferson Cowie and Joseph Heathcott, Beyond the Ruins: The Meanings of Deindustrialization: The Meanings of Deindustrialization (Ithaca: Ilr Press Books, Cornell University Press, 2003), 3.

19 Joanna Sage, Darren Smith, and Phil Hubbard, "The Diverse Geographies of Studentification: Living Alongside People Not Like Us," Housing Studies, Vol. 27, No. 8 (November 2012): 1057-1076; Graham Pickren, "Where Can I Build My Student Housing? The Politics of Studentification in Athens-Clarke County, Georgia," Southeastern Geographer, Vol. 52 No. 2 (Summer 2012): 116-119; Ray Bromley, "On and Off Campus: Colleges and Universities and Local Stakeholders," Planning, Practice \& Research, Vol. 21, No. 1 (February 2006 ): 6.
} 
documented and informally remembered within the institutional community. ${ }^{20} \mathrm{WVU}$ 's consideration for its image is informed by a broader consideration for the mark it leaves on history and the role it plays in narratives from the global to the individual. Helen Lefkowitz Horowitz provides a cultural perspective on changes in higher education in Campus Life: Undergraduate Cultures from the End of the Eighteenth Century to the Present (1987).

The socially and culturally distinct university setting also brings forth discussions of individuality and fellowship, both of which are integral to the college experience depending upon the time period and university. Sometimes, these discussions are framed by gender, race, and the fraternal or collegiate organizations built around those structures, such as Barbara Miller Solomon's In the Company of Educated Women: A History of Women and Higher Education in America (1985), Nicholas L. Syrett's In the Company He Keeps: A History of White College Fraternities (2009), Babette Faehmel's College Women in the Nuclear Age: Cultural Literacy and Female Identity, 1940-1960 (2012). These works demonstrate that student experiences are less homogenized than the "student" label often imagines. Although this thesis only skims the surface of gender, race, and politics, these concepts help frame broader discussions of university culture and student identity. Sociological works such as by Harry Wechsler and Bernice Wuethrich's Dying to Drink: Confronting Binge Drinking on College Campuses (2002), John J. Sloan III and Bonnie S. Fisher's The Dark Side of the Ivory Tower: Campus Crime as a Social Problem (2011), Karen G. Weiss's Party School: Crime, Campus, and Community (2013) and studies on student drinking habits provide a modern contextualization of student culture. ${ }^{21}$

\footnotetext{
${ }^{20}$ John R. Thelin, A History of American Higher Education (Baltimore: Johns Hopkins University Press, 2004), $\mathrm{xx}$

${ }^{21}$ Andy Soon Leong Tan, "Through the Drinking Glass: An Analysis of the Cultural Meanings of College Drinking,” Journal of Youth Studies, Vol. 15, No. 1 (February 2012): 119-142.
} 
The college town's student population, though transient, build a sense of culture and community. Works on memory, therefore, contribute to discussions of how neighborhoods like Sunnyside and the activities that occur there are remembered. Nostalgia is a strong emotion present in many student and alumni writings, which frame critical discussions of how student traditions are carried on and negative behaviors are justified within certain contexts. The Imagined Past: History and Nostalgia (1989), edited by Christopher Shaw and Malcolm Chase, chapters in Alison Isenberg's Downtown America, Blake Gumprecht's The American College Town, and Karen Weiss's Party School, and select articles, help frame discussions of nostalgia and romanticism. ${ }^{22}$

Finally, I build off the work of history instructor Jenny Boulware and her students at WVU. The histories they have written respond to recent redevelopment in the neighborhood and preserve little-known stories of Sunnyside. Their publication in West Virginia History, "Glass Blowing and Community Building: A History of Morgantown, West Virginia's Sunnyside Neighborhood, 1890-2013," provides an in-depth look at varying groups, places, and events in Sunnyside over the past 120 years.

\section{Organization}

This thesis is organized in three chapters that address residential shifts, off-campus housing dilemmas, and the "Sunnyside problem." Questions of identity and memory are relevant throughout. Chapter One provides a "snapshot" of 120 years in Sunnyside using a microhistorical approach. Through microhistory, a pluralistic image of Sunnyside emerges,

\footnotetext{
${ }^{22}$ Barbara Shircliffe, "'We Got the Best of That World': A Case for the Study of Nostalgia in the Oral History of School Segregation,” The Oral History Review, Vol. 28, No. 2 (Summer-Autumn 2001): 59-84; ,Sergio Davalos, et al. "'The good old days': An Examination of Nostalgia in Facebook Posts," International Journal Of Human-Computer Studies, Vol. 83, (November 2015): 83-93.
} 
complicating generalized narratives on the neighborhood's history. ${ }^{23}$ The 2100 block constitutes an ideal site of study. It is located in the heart of Sunnyside on University Avenue, the street that eventually runs directly through the Downtown campus of WVU, and Grant Street, known in recent history for its student block parties. Most of the 39 structures in this block were from the late nineteenth and early twentieth centuries, home to industrial workers, families, students, and a few small businesses, including a grocery store, auto shop, and bars like Mutt's Sunnyside Pub. In the 1920s and 1930s, fraternities and sororities briefly lined the University Avenue near the 2100 block before moving to High Street's fraternity row. In 2013, the 2100 block of Sunnyside was leveled and construction began on University Place, an eight-story multiuse apartment complex promising housing and amenities for hundreds of students. By tracing the history of a few houses and their occupants over the course of 120 years, a few distinct "ages" can be identified that reflect shifts in local industry, the University, and residential patterns.

In chapters two and three, I focus on WVU students from the 1960s through the 1980s, the timeframe in which Sunnyside transforms into a student neighborhood. The second chapter examines Morgantown more broadly as a college town and the University's shift toward creating a student-centered institution. ${ }^{24}$ Through research, discussions of freedom, responsibility, and adulthood appeared in student writings about their relationships with the University. John R. Thelin's A History of American Higher Education proposes that postwar universities were “marked by the 'three P's' of prosperity, prestige, and popularity,” providing access to the masses. ${ }^{25}$ This era saw the breaking down of traditional in loco parentis policies. Housing, like dress and class attendance, affected students on a day-to-day basis, especially because traditional

23 Sigurdur Gylfi Magnusson, "What is Microhistory?" History News Network, May 7, 2006, accessed March 26, 2017, http://historynewsnetwork.org/article/23720.

${ }^{24}$ Lewis, Aspiring to Greatness, 305, 469.

${ }^{25}$ Thelin, A History of American Higher Education, 260. 
undergraduates were and continue to be young and living away from home for the first time. As young adults, students "often think of independence as being freedom from something rather than as a course of action that requires living within the dictates of society," while simultaneously, universities impose rules and regulations that "depress and restrict creative criticism and action."26 By the 1960s, students began to question these structures, influenced by a recent history of social and civil rights movements. ${ }^{27}$ Although WVU was not a revolutionary campus, the breadth of student movement culture infiltrated their discussions and overflowed into the city of Morgantown. Examples of student movement appeared in more classically radical forms, such as a few left-wing activist groups, and in more subdued, yet powerful, forms, such as WVU's students influence on a local housing referendum in 1979.

The third chapter focuses conceptions of student identities within Sunnyside. Since the 1970s, Sunnyside has encountered two distinct yet interrelated challenges. The first is the "Sunnyside problem," which encompasses mix of environmental and social issues occurring within the neighborhood. The environmental problems involve off-campus housing conditions, which are discussed primarily in Chapter Two. The social problems involve student parties, ranging from a less conspicuous house gatherings to raging block parties that police, firefighters, city officials, and WVU administrators could not ignore. The infamy of such parties contributed to Sunnyside's second challenge, WVU's label as the "\#1 party school.” Members of the WVU community have either refuted or embraced contentious nickname over the past forty years. When the label gained notoriety in the 1970s, the definition of a "party school" was more ambiguous. Sociologist Dr. Karen Weiss, a professor at WVU, defines a party school as a place

\footnotetext{
${ }^{26}$ Arthur H. Kiendl, “Academic Round Table: In Loco Parentis,” The Journal of Higher Education Vol. 34, No. 8 (1963): 465.

${ }^{27}$ Kiendl, "Academic Round Table: In Loco Parentis," 466.
} 
where a "disproportionate number of students eager to boast of their party-related 'accomplishments"' and in which students perceive higher education as an opportunity to gain social experiences and prioritize these experiences over scholastic growth. ${ }^{28}$ Looking at this label from a historical perspective sheds light on how students have developed and perpetuated Sunnyside partying as an essential "WVU experience." The Sunnyside mythos can be interpreted through lenses of student freedom, tradition, and romanticism, which draw out a variety of student perceptions. Some members of the WVU community, in contrast, expressed concerns for how this image would reflect upon their reputation. As a university that had to combat Appalachian stereotypes, WVU's struggles with the Sunnyside problem and party school image parallel past struggles with the school mascot, the Mountaineer, who transformed from a "hillbilly" caricature to a pioneering "frontiersman.",29

The story of Sunnyside involves an interplay of people and place, which change over time. As a cultural landscape, Sunnyside has become integral to student folklore, traditions, and memories. Questions of identity are especially pertinent among college students, a distinct group of individuals who often pursue higher education to find their place in the world. As public historian Dolores Hayden wrote, "Identity is intimately tied to memory: both our personal memories (where we have come from and where we have dwelt) and the collective or social memories interconnected with the histories of our families, neighbors, fellow workers, and ethnic communities. ${ }^{30}$ On a day to day basis, Sunnyside has historically served as a backdrop to

${ }^{28}$ Karen G. Weiss, Party School: Party School: Crime, Campus, and Community (Boston: Northeastern University Press, 2013), xiii-xv; Allie Grasgreen, "Party School," Interview with Karen Weiss, December 3, 2013, accessed March 25, 2017. https://www.insidehighered.com/news/2013/12/03/book-details-campus-and-communityconsequences-party-school-culture.

${ }^{29}$ Rosemary Hathaway, "From Hillbilly to Frontiersman: The Changing Nature of the WVU Mountaineer," West Virginia History Vol. 8, No. 2 (Fall 2014): 15-16.

${ }^{30}$ Hayden, The Power of Place, 9. 
students' lives. After football games, a new fall semester, or a break in winter weather, Sunnyside became the stage on which students produced wild and controversial performances.

Today, the stage is being reset. The University, the city, and local nonprofits promote revitalization. These efforts are met with mixed reactions; some argue that reimagining Sunnyside will help resolve problems and provide students with essential services, while others see new construction and commercialization as a threat to the neighborhood's authentic character. These contemporary perspectives invite a nuanced look into Sunnyside's history. 


\section{CHAPTER ONE}

\section{A Microhistory of Sunnyside}

As a cultural landscape, Sunnyside reflects the ephemeral nature of built environments. ${ }^{1}$ For the past 120 years, Sunnyside has been home to diverse, transient communities. However, during the past two decades, Sunnyside has undergone significant revitalization projects. Since 2004, six large-scale, mixed-use complexes have been developed in Sunnyside, with more projects in the imminent future. WVU, local developers, and local nonprofits initiated these projects to combat the neighborhood's deterioration by providing new apartments, commercial opportunities, and parking for students and four-season residents alike. ${ }^{2}$

Among the most controversial projects is University Place, an eight-story apartment complex opened in 2014. Although it offers top amenities highly sought-after by incoming students, University Place's location in Sunnyside received criticism, especially from student tenants who were forced to move from their homes to make way for new construction.

Accusations of corporate greed, misguided objectives, and destruction of tradition demonstrate that Morgantown's student housing issue is far more complicated than having enough beds for students each fall. ${ }^{3}$ It conveys a student experience that it seemed only Sunnyside could offer.

\footnotetext{
${ }^{1}$ Cowie and Heathcott, Beyond the Ruins, 5.

${ }^{2}$ West Virginia University Facilities Planning, West Virginia University: Main Campus Student Housing Master Plan - 2012 (Morgantown: West Virginia University, last updated September 28, 2012), accessed April 3, 2017. http://facilitiesplanning.wvu.edu/files/d/25ad7fe5-b23c-432b-9f1b-00b3cd531b12/student-housing-materplan-2012.pdf; West Virginia University Facilities Planning, West Virginia University: Ten-Year Campus Master Plan (Morgantown: West Virginia University, 2012), 13, accessed April 23, 2016. http://facilitiesplanning.wvu.edu/files/d/a3d8ebd1-edc5-4a3a-9dc2-e3fcadfb1cd7/campus-master-plan-2012.pdf; Frank Scafella, "On the Threshold of Urbanity," Campus Neighborhoods Revitalization Corps Annual Report 2015, (Morgantown: Campus Neighborhoods Revitalization Corps, 2015), 2-3, http://sunnysideupwv.org/images/page_001.pdf.

${ }^{3}$ Carlee Lammers, "Students react to news of University's $\$ 70$ million plan for 'University Place' in Sunnyside," The Daily Athenaeum, October 29, 2012, accessed April 24, 2017, http://www.thedaonline.com/article_075625f2-7fa4-5894-8fcd-83bc1804ac05.html; David Schlake, "University Place: the wrong move for WVU," The Daily Athenaeum, April 17, 2014, accessed April 24, 2017, http://www.thedaonline.com/opinion/article_2a4c02c4-c5fe-11e3-af25-0017a43b2370.html; Emily Leslie, "What
} 
Prior to the construction of University Place, a mix of 39 homes and structures occupied this site. The block's first constructions date to the 1890s. It is framed by two streets commonly associated with West Virginia University culture. On the northeast side is University Avenue (formerly Beverly Avenue), a street that eventually runs directly through the Downtown campus. On the southwest side is Grant Street, where some of the most notorious college parties have taken place in Morgantown. The structures that once stood in this block reflect historical residential and commercial patterns across Sunnyside. Constructed for single families in the late nineteenth and early twentieth centuries, the homes accommodate short-term residents, long-term residents, and boarders. Still, these structures served as more than homes. Within the 2100 block, businesses such as grocery stores, automobile shops, a tiling business, and a bar have thrived.

The footprint of University Place, therefore, symbolizes the arc of Sunnyside's history. Through closer study of the people and homes that once resided there, a more detailed and complex image of Sunnyside emerges. Three of these residences best tell the story. From the 1890 s to the 1920 s, an industrial worker population, many of whom rented homes or lived as boarders, dominated Sunnyside. The use of 91 Beverly Avenue / 2125 University Avenue as a home for glassworkers represents a common pattern in Sunnyside amid its industrial age. ${ }^{4}$ Beginning in the 1920s, small businesses began to appear in Sunnyside. The "dawn of small business" was both a cause of and an effect of Mountaineer Field, WVU's football stadium, built in the 1920s between the Downtown campus of WVU and Sunnyside. 2157 University Avenue, home to a few generations of business owners, helps explore these changes. The last two sections on the postwar "University growth" and the "student age" are best told through 2129 University

\footnotetext{
happened to Sunnyside? Where did it all go?" The Daily Athenaeum, May 12, 2015, accessed April 24, 2017, http://www.thedaonline.com/news/article_fbefe0fe-f382-11e4-b08d-0fd201495fde.html.

${ }^{4}$ Jenny Boulware and Andrew Mach, "Glass Blowing and Community Building: A History of Morgantown, West Virginia's Sunnyside Neighborhood,” West Virginia History Vol. 9, No. 1 (Spring 2015): $72-73$.
} 
Avenue, a home that a student on the GI Bill rented that was later converted into one of Sunnyside's most beloved taverns.

Morgantown saw transformative and enduring developments in the late nineteenth and early twentieth century. After more than a century of heavy industry, agriculture, and manufacturing, new systems of transportation and communication made places, people, and resources accessible like never before. The first railways cut through the city in 1886, when the Baltimore and Ohio Railroad opened a branch between Morgantown and Fairmont, with connections as far as New York City and St. Louis. The Fairmont, Morgantown, and Pittsburgh Railroad furnished the city with raw materials and, in turn, attracted factories to Morgantown. These railways also facilitated coal mine development in the outlying areas of the city and neighboring cities such as Fairmont. Morgantown's river highway, the Monongahela, carried a line of first-class steamboats arriving and departing each day, securing waterway communications with Pittsburgh. The use of railroads and steamboats forged stronger connections with other cities and encouraged development within Morgantown. By the mid1890s, the city boasted manufacturers, flour and corn mills, a foundry, a creamery, and a brick company. ${ }^{5}$

Prominent Morgantown citizens harnessed the potential of these new systems and sought to advance the city's growth. After organizing a Chamber of Commerce in 1889, a handful of those Chamber members formed the Morgantown Building and Investment Company (MBIC) in January 1892 , to expand the railroad and encourage industrial and residential development. The

\footnotetext{
${ }^{5}$ West Virginia University Public History Option, Morgantown: A Bicentennial History (Morgantown, WV, 1985), 4; Otis K. Rice and Stephen W. Brown, West Virginia: A History, Second edition (Lexington: University of Kentucky, 1993), 186-187; James Morton Callahan, History of the Making of Morgantown, West Virginia: A Type Study in Trans-Appalachian Local History (Morgantown, WV: Morgantown Printing and Binding Company, 1926), 172; Prospectus of the Morgantown Building and Investment Company, 9-10
} 
MBIC purchased briar fields below Falling Run that would soon become Sunnyside. Within the year, the company constructed Beechurst Avenue, and a few years later, successfully extended the railroad to important western Pennsylvania industrial centers such as Uniontown, Connellsville, and Pittsburgh. ${ }^{6}$

The MBIC enticed both industry and residents to settle in Sunnyside with declarations that the hills surrounding Morgantown were rich in mineral resources including bituminous coal, coke, limestone, clay, sand, and iron ore. These hills provided the "gateway to West Virginia's wealth." Morgantown's location near and exclusive use of Monongalia County's "Natural Gas Belt," would provide clean and cost-efficient fuel for factories as well as homes. ${ }^{7}$ The MBIC experienced some early failure with enterprises on the land; the Farrow Arms factory, for example, only lasted a few months due to insufficient capital and had to close in 1894 . In contrast, Seneca Glass Company, built along the Monongahela River in 1896, firmly established itself in this newly developed area. After exhausting their natural gas supply in Ohio, Seneca was attracted to the offer of free land and an allowance for monthly gas. To accommodate the hundreds of workers that would fill Seneca and many other factories that followed, houses appeared across Beechurst Avenue in a neighborhood known as the Beechurst Addition or Seneca, which in turn stimulated residential development further up the hill. This neighborhood, Sunnyside, was well connected to the area across Falling Run after a private footbridge was built in $1894 .^{8}$

\footnotetext{
${ }^{6}$ Callahan, History of the Making of Morgantown, 248-252.

${ }^{7}$ Prospectus of the Morgantown Building and Investment Company, 7-8, 12.

${ }^{8}$ Callahan, History of the Making of Morgantown, 248-252.
} 
The Clarksburg Telegram reported this "pretty suburb of Morgantown” grew rapidly over the summer of 1896 , with plans to build more homes and open stores. ${ }^{9}$ Aside from the houses demolished to make way for new construction, many of the houses built in Sunnyside's early history still stand today. Modified over the centuries, these houses help tell a story of the neighborhood and the people who lived there.

The Industrial Age: 1890 s - 1925

91 Beverly Avenue / 2125 University Avenue

Developers built Sunnyside with a clear purpose in mind: to house Morgantown's industrial workers. Between 1896 and 1911, twelve glass factories sprung up along the Monongahela River. The natural and built environments of West Virginia, along with its neighbors Pennsylvania and Ohio, comprised a "Glass Triangle," sharing five primary factors that contributed to the glass industry's success: close proximity to raw materials, fuels, labor, markets, and transportation. ${ }^{10}$ With these glass factories came additional railways, roads, and streetcar systems to move people and resources within the city of Morgantown and beyond. Between 1890 and 1900, the city of Morgantown nearly doubled in size from approximately 3,000 residents to 5,300 residents. In this time, the Seneca district housed more than 700 residents in the few years that housing was available. ${ }^{11}$

In the early 1900s, developer J.W. Wiles emphasized Sunnyside's location as providing opportunity for "each member of the family to earn a respectable wage." 12 This early period,

\footnotetext{
9 "State Items," The Clarksburg Telegram, September 4, 1896. Chronicling America: Historic American Newspapers, Library of Congress. http://chroniclingamerica.loc.gov/lccn/sn84037844/1896-09-04/ed-1/seq-5/.

${ }^{10}$ Robert Stanley Weiner, The Location and Distribution of the Glass Industry of Ohio, Pennsylvania, and West Virginia (Master's thesis, University of Pittsburgh, 1949), 8-9, 24.

${ }_{11}$ Core, The Monongalia Story: A Bicentennial History, vol. 4, Industrialization, 253.

${ }^{12}$ Wiles, J.W. Morgantown's Suburbs. West Virginia and Regional History Collection.
} 
therefore, was an "industrial age" of Sunnyside in which local industries shaped its residential population. At 91 Beverly Avenue, two families, the Becketts and the Grahams, along with their boarders, represent workers in the glass industry as well as other area of employment in Morgantown. Between the 1890s and 1920s, many Sunnyside residents followed similar patterns of living and working as the Becketts and Grahams on Beverly Avenue. Their neighbors were tied to local industry in varying capacities.

91 Beverly (later 2125 University Avenue) was a two-story frame house, asymmetrically designed with a large porch and hip roofs. Although modest in architectural design, 91 Beverly, like its neighbors, was large enough to comfortably hold a single family, multiple families, or families with boarders. The construction, therefore, reflects builders' expectations that Sunnyside would be home to the local working class. ${ }^{13}$

The Beckett family exemplifies multifamily living that often occurred in Sunnyside in this industrial period. They moved from Ritchie County, West Virginia, to Morgantown by 1910 and rented 91 Beverly from Elizabeth Price, who lived on Walnut Street and whose husband owned a successful furniture store in town. ${ }^{14}$ Sherman Beckett, a native West Virginian, worked as a snapper in a local glass factory. He lived with his father, mother, and siblings, along with his own wife and children, along with three boarders. This busy household reflects the way Sunnyside's houses accommodated numerous individuals.

\footnotetext{
13 Thomas J. Schlereth, Victorian America: Transformations in Everyday Life, 1876-1915 (New York: HarperCollins Publishers, 1991), 95-96, 100-101.

141910 U.S. Census, Morgantown, Monongalia County, p. 12B, Sherman R. Beckett, digital image, Ancestrylibrary.com, accessed Feb. 24, 2017. http://search.ancestrylibrary.com/cgibin/sse.dll?_phsrc $=O$ OSa2\&_phstart $=$ successSource\&usePUBJs $=$ true \&gss $=$ angs$\mathrm{c} \&$ new $=1 \& \mathrm{rank}=1 \& \mathrm{msT}=1 \& \mathrm{gsfn}=$ sherman\&gsfn_x$=0 \& \mathrm{gs} \ln =$ beckett\&gsln_x $=0 \& \mathrm{MSAV}=1 \&$ uidh=xq3\&pcat=35\& h=30403737\&dbid=7884\&indiv=1\&ml_rpos=8; Polk's Morgantown City Directory (Pittsburgh: R.L. Polk and Company, Publishers, 1910), 219-219.
} 
Taking in boarders provided an additional stream of income for families like the Becketts, who may have needed additional financial support even with stable employment. As a snapper, an unskilled position, Beckett may have been struggling to move upward in the glass factory. ${ }^{15}$ The women in the household, who were listed on the census as working at home, likely cared for boarders by making meals and cleaning. Although it would have added to their workload, boarding allowed women to remain at home and support the family's additional source of income. Designated boarding houses were available in Morgantown, primarily located outside of Sunnyside on High Street; only one boarding house was in Sunnyside on Beechurst Avenue. However, most boarders in Sunnyside lived with families who owned and resided at their own homes, some of whom were industrial workers, and some not. The need for boarders also reflects the Becketts as tenants rather than homeowners, who opened their home and provided a service to their boarders. The Becketts' boarders, Lena Reid and sisters Sybil and Ada McFarland, workers at a local publishing house, typified boarders of the early twentieth century. They were young, single, and working class, and likely knew each other before boarding together. ${ }^{16}$

Students were also among Sunnyside's early residents. Even more transient than industrial workers, students also boarded in the homes of permanent residents. Developers like J.W. Wiles explained the economic value of boarding students: "Two students rent your room,

\footnotetext{
${ }^{15} 1910$ U.S. Census, Morgantown, Monongalia County, p. 12B, Sherman R. Beckett, digital image, Ancestrylibrary.com, accessed Feb. 24, 2017. http://search.ancestrylibrary.com/cgibin/sse.dll?_phsrc $=O$ OSa2\&_phstart $=$ successSource\&usePUBJs $=$ true \&gss $=$ angsc\&new $=1 \&$ rank $=1 \& \mathrm{msT}=1 \& \mathrm{gsfn}=$ sherman\&gsfn_x=0\&gsln=beckett\&gsln_x=0\&MSAV=1\&uidh=xq3\&pcat=35\& $\mathrm{h}=30403737 \&$ dbid=7884\&indiv=1\&ml_rpos=8; 1920, U.S. Census, Morgantown, Monongalia County, p. 4B, Sherman R. Beckett, digital image, Ancestrylibrary.com, accessed Feb. 24, 2017, Fones-Wolf, Glass Towns, 36-40, 74-76. Sherman Beckett's financial situation may also explain why his stay in 91 Beverly Avenue was relatively short. By 1920, he worked for a telephone company and lived elsewhere in town.

${ }^{16}$ Polk's Morgantown City Directory (Pittsburgh: R.L. Polk and Company, Publishers, 1915-1916), 265; Schlereth, Victorian America, 103-106; Boulware and Mach, "Glass Blowing and Community Building," 72.
} 
you furnishing everything, except light, soap, and towels; they pay a rental of 75 cents to $\$ 1.25$ per week, thus making at the lowest calculation...\$72.00 per year. If you rent four rooms you have $\$ 288.00$ per year." 17

In addition to workers, Sunnyside housed its share of managers, foremen, and contractors. Their presence demonstrates the economic and employment diversity of Sunnyside residents. Most heads of local industry clustered in more affluent areas of town. Seneca Glass Company's longtime manager, Joseph Haden, for example, lived on Waitman Street in South Park, one of Morgantown's nicest neighborhoods. ${ }^{18}$ Sunnyside, however, housed upper-level workers in a variety of housing situations. In 1920, glass foreman William Graham lived at and owned 91 Beverly. He earned a salary wage like his adult daughter, Nellie, who worked as a typist at WVU. ${ }^{19}$ Still, not all managers owned their homes. Oscar Hall, a manager at the Morgantown Ice Company, and his family were boarders at 107 Beverly, sharing a home with a butcher and his large family. ${ }^{20}$

Sunnyside residents also supported themselves with through small businesses or working in non-industrial positions. This employment diversity shows early inklings of Sunnyside as a mixed-use neighborhood. Claude McKinney, for example, owned and operated an automobile shop, located behind the house he owned at 95 Beverly. ${ }^{21}$ Most businesses during the early

\footnotetext{
${ }^{17}$ Wiles, J.W. Morgantown's Suburbs, 24-26.

181930 U.S. Census, Morgantown, Monongalia County, p. 20B, Joseph Haden, digital image, Ancestrylibrary.com, accessed Feb. 9, 2017. http://search.ancestrylibrary.com/cgibin/sse.dll?_phsrc=ABM6\&_phstart=successSource\&usePUBJs $=$ true\&gss $=$ angsg\&new $=1 \&$ rank $=1 \&$ msT $=1 \& g s f n=j o s e p h \& g s f n \_x=0 \& g s \ln =$ haden\&gsln_x=0\&msypn_ftp=Morgantown, $\% 20 \mathrm{Mon}$ ongalia, \%20West\%20Virginia,\%20USA\&msypn=25073\&msypn_PInfo=8$\% 7 \mathrm{C} 0 \% 7 \mathrm{C} 1652393 \% 7 \mathrm{C} 0 \% 7 \mathrm{C} 2 \% 7 \mathrm{C} 0 \% 7 \mathrm{C} 51 \% 7 \mathrm{C} 0 \% 7 \mathrm{C} 2051 \% 7 \mathrm{C} 25073 \% 7 \mathrm{C} 0 \% 7 \mathrm{C} 0 \% 7 \mathrm{C} \& \mathrm{MSAV}=0 \& \mathrm{catbucket}=\mathrm{r}$ stp\&uidh=xq3\&pcat=ROOT_CATEGORY\&h=100686609\&dbid=6224\&indiv=1\&ml_rpos=2

191920 U.S. Census, Morgantown, Monongalia County, p. 1A, William Graham, digital image, Ancestrylibrary.com, accessed Feb. 9, 2017.

${ }^{20} 1920$ U.S. Census, Morgantown, Monongalia County, p. 1A, Oscar Hall, digital image, Ancestrylibrary.com, accessed Feb. 9, 2017.

${ }^{21} 1920$ U.S. Census, Morgantown, Monongalia County, p. 1B, Claude McKinney, digital image, Ancestrylibrary.com, accessed Feb. 9, 2017.
} 
twentieth century were concentrated along Front Street, now known as Beechurst Avenue. Other residents, such as the Garretts, a set of siblings in their late twenties and early thirties, worked as musicians for a local theatre. ${ }^{22}$

Diversity also carried over into ethnic diversity, as the industries attracted immigrants from Germany, Belgium, France, Italy, Sweden, and Hungary, as well as Americans from other states. These cultures also instilled Sunnyside with transnational languages, religions, civic organizations, and ethnic traditions; classes and ethnic groups tended to cluster in informally segregated areas. ${ }^{23}$ Furthermore, like most suburbs in Morgantown, Sunnyside housing could not be "sold or rented to people of other than the Caucasian race" during this time. ${ }^{24}$

91 Beverly Avenue shows West Virginian families coming to Morgantown to make a living in local industry. Like many others, the families at 91 Beverly were transient and supported their stay in Morgantown through group housing and boarders. The structures surrounding 91 Beverly also diversify this narrative with non-industrial workers, students, and budding businesses.

\section{The Dawn of Small Business: 1925 - 1945}

\section{University Avenue}

By the 1920s, this block of Sunnyside began to transform. As industry powered on, businesses began appearing to provide more accommodations and services. By 1925, a stretch of Beverly Avenue was renamed University Avenue, a symbolic reflection of WVU's increasing influence on Sunnyside. The neighborhood welcomed Greek houses and, most notably, a large

221920 U.S. Census, Morgantown, Monongalia County, p. 1B, Guy Garrett, digital image, Ancestrylibrary.com, accessed Feb. 9, 2017.

${ }^{23}$ Boulware and Mach, "Glass Blowing and Community Building," 69-72.

${ }^{24}$ Wiles, J.W. Morgantown's Suburbs, 24-26. 
football stadium. Amid these changes, 2157 University Avenue served as both a business and residential structure. Like the apartment complex that would be built in its place almost ninety years later, 2157 University reflects a shift toward dual residential and commercial opportunities in Sunnyside.

In 1923, Morgantown native Edward F. Davis purchased 2157 University Avenue, beginning a small business that would remain in Sunnyside for decades. Davis had worked in the tiling industry since at least 1900 , first as a tile setter. ${ }^{25} \mathrm{He}$ and his family moved from Falling Run Road to Sunnyside where he purchased 2157 University Avenue and opened Edward F. Davis Mantles and Tile. ${ }^{26}$ Unlike neighboring houses, which were two- and three-story frame structures, 2157 University was boxy, nearly four stories high, and made of brick.

Davis opened his business in a time when Sunnyside offered services beyond housing to residents. Between 1925 and 1945, Sunnyside, like the rest of Morgantown, saw growth in small businesses. In 1915, for example, Morgantown had around 50 grocery stores; by 1925, that number had more than doubled, expanding services out to the coal community of Sabraton. ${ }^{27}$ Similarly, Morgantown's population had also more than doubled, expanding from 9,000 citizens in 1910 to 20,000 in $1920 .^{28}$ University Avenue became a particularly lucrative area for small businesses, serving as a counterweight for the older businesses along Beechurst Avenue. In the 1920s, a variety of businesses appeared along University Avenue; these automobile shops,

251900 U.S. Census, Masontown, Fayette County, Pennsylvania. p. 138A, Edward Davis, digital image, Ancestrylibrary.com, accessed February 9, 2017. http://search.ancestrylibrary.com/cgi-

bin/sse.dll? indiv $=1 \& \mathrm{db}=1900$ usfedcen $\& \mathrm{~h}=62711031 \& \mathrm{tid}=\& \mathrm{pid}=\&$ usePUB $=$ true $\& \_$phsrc $=$wfg $1 \& \_$phstart $=$success $S$ ource\&usePUBJs $=$ true \&rhSource $=7884$

${ }^{26}$ Monongalia County, West Virginia, Deed Book 186, p. 217; Herbert G. Gilmore, Dora K. Gilmore, William H. Gilmore, Maud Ashcraft and William Ashcraft, Florence C. Wilbourn and Charles R. Wilbourn to H. Lloyd Smith and Edward F. Davis, April 19, 1923; Office of the Recorder of Deeds, City of Morgantown.

${ }^{27}$ Polk's Morgantown City Directory (Pittsburgh: R.L. Polk and Company, Publishers, 1915-1916), $275-$ 276; Polk's Morgantown City Directory (Pittsburgh: R.L. Polk and Company, Publishers, 1925), 821-824.

${ }^{28}$ William T. Doherty Jr. and Festus P. Summers, West Virginia University: Symbol of Unity in a Sectionalized State (Morgantown, WV: West Virginia University Press, 1982), 108. 
service stations, shoe repair shops, groceries, markets, barbers, laundries, and drugstores provided services to the upper streets of Sunnyside. ${ }^{29}$ Yet the most significant addition to the area was Mountaineer Field, WVU's 34,000-seat football stadium bordering Sunnyside along Campus Drive. These new public spaces in Sunnyside invited students and citizens to find housing, work, and recreation, along with opportunities to have closer and more frequent contact with one another.

In the early twentieth century, WVU, like most universities, remained insular and concerned with campus activities. Institutional historians William Doherty, Jr. and Festus Summers argue that students and faculty at WVU were "absorbed in their own campus lives.",30 In the 1920s, however, students began asserting themselves in ways that illustrate their increasing community influence. They formed organizations such as student councils, religious groups, Greek houses, and clubs through which they could self-identify. Groups of students advocated for prices they considered more sensitive to the college lifestyle, initiating boycotts, petitions, and newspaper campaigns that prompted local businesses to lower prices on drinks, restaurant meals, and haircuts. ${ }^{31}$

In the 1920s, Greek housing appeared in Sunnyside for the first time. Fraternities and sororities concentrated groups of like-minded students who were likely branching out on their own for the first time. Greek housing was purposefully exclusive and segregated from the rest of the student body. Often, Greek houses were expensive, with beautiful architecture and top-notch amenities provided by generous alumni. The 1920s were a period of great expansion for

\footnotetext{
${ }^{29}$ Polk's Morgantown City Directory (Pittsburgh: R.L. Polk and Company, Publishers, 1929-1930), 581; Polk's Morgantown City Directory (Pittsburgh: R.L. Polk and Company, Publishers, 1945), 470.

${ }^{30}$ Doherty and Summers, West Virginia University, 128.

${ }^{31}$ Ibid, 120-121, 128.
} 
fraternities nationally, a trend visible at WVU, in which numerous chapters opened. ${ }^{32}$ Although by the mid-1930s, the Greek houses along University Avenue moved to the other side of town on High Street, where most remain today, their brief stay in Sunnyside is significant to the neighborhood's history.

Dedicated in 1925, Mountaineer Field signified that Morgantown had become a "college town." No other university department had more power to bring together students, alumni, and local citizens than athletics, a symbiotic relationship unique to the United States. ${ }^{33}$ Mountaineer Field was built amidst the "Golden Age of American sports." Athletics put American values of competition, physical strength, moral health, and character-building on fields, tracks, and stadiums of universities, where students' minds and bodies would be equally enriched. ${ }^{34}$ West Virginia led the country in natural gas and coal extraction, bringing wealth and attention to the state. Sports, however, also became a method for West Virginia to distinguish itself in the nation and find "unifying symbols" that were necessary for an isolated, sectionalized state. ${ }^{35}$ These unifying symbols were also powerful within individual college towns where there are often more stadium seats than citizens. ${ }^{36}$ In Morgantown, the construction of Mountaineer Field, therefore, not only transformed Sunnyside but the entire city into a Mecca for fans of WVU sports.

Savvy entrepreneurs responded to Mountaineer Field's appearance. In 1925, University Avenue was home to ten small businesses. By 1935, that number grew to seventeen, and then to

\footnotetext{
32 Polk's Morgantown City Directory (Pittsburgh: R.L. Polk and Company, Publishers, 1922), 119; Polk's Morgantown City Directory (Pittsburgh: R.L. Polk and Company, Publishers, 1929-1930), 581; Gumprecht, The American College Town, 75; Nicholas L. Syrett, In the Company He Keeps: A History of White College Fraternities (Chapel Hill: The University of North Carolina Press, 2009), 162-163, 208; Fraternities and sororities included Phi Delta Lambda, Phi Delta Theta, and Chi Delta Phi, Alpha Gamma Rho, Theta Kappa Psi, and Alpha Delta Pi.

${ }^{33}$ Gumprecht, The American College Town, 227.

${ }^{34}$ Bob Barnett, Hillside Fields: A History of Sports in West Virginia (Morgantown, WV: West Virginia University Press, 2013), xvi.

${ }_{35}$ Barnett, Hillside Fields, xv.

${ }^{36}$ Gumprecht, The American College Town, 227.
} 
twenty-two a few years later. ${ }^{37}$ Just down the street from Davis's tiling company, Charles B. Morris purchased 2121 University Avenue from bakery manager, Samuel Herkshovitz, with hopes of opening his own small business. ${ }^{38}$ Morris opened a grocery store around 1925.

Groceries, markets, service stations, cleaners, and barber shops were among the most common businesses opening in Sunnyside into the 1940s. Many of these businesses also adopted "Sunnyside" in their names. Some businesses, such as Howard Johnson's Barber Shop, renamed themselves to include the word "Sunnyside." 39 Newer businesses appearing along University Avenue in the late 1920s to the 1940s, including Sunnyside Cleaning and Pressing Company, Sunnyside Shoe Repair, Sunnyside Fruit Market, and Sunnyside Grill, may have been identifying themselves with the growing neighborhood. ${ }^{40}$ Other businesses, such as the Stadium Inn, preferred to emphasize Mountaineer Field's presence.

2157 University Avenue was home to more than Edward Davis's tiling shop. It was also where several boarders associated with WVU lived. In 1930, Edward and Sadie Davis rented rooms to Ruth Simenson and Evelyn Dijou, teachers at WVU. By 1940, the number of boarders increased to eight. Four of the women were secretaries or assistants at WVU, one was an instructor at WVU, and two worked for local public schools. These women, all single and varying in age from 22 to 68 , reflect gendered patterns of living in the neighborhood. Others who lived on the block worked in close association with the university and its students, including Virginia Madigan, a librarian, and John and Emma Ervin, cooks at a local fraternity house.

\footnotetext{
${ }^{37}$ Polk's Morgantown City Directory (Pittsburgh: R.L. Polk and Company, Publishers, 1925), 756-757; Polk's Morgantown City Directory (Pittsburgh: R.L. Polk and Company, Publishers, 1935), 410; Polk's Morgantown City Directory (Pittsburgh: R.L. Polk and Company, Publishers, 1941), 548.

${ }^{38}$ Monongalia County, West Virginia, Deed Book 186, p. 217; Samuel Herkshovitz to Charles B. Morris, February 21, 1923; Office of the Recorder of Deeds, City of Morgantown.

${ }^{39}$ Polk's Morgantown City Directory (Pittsburgh: R.L. Polk and Company, Publishers, 1925), 756; Polk's Morgantown City Directory (Pittsburgh: R.L. Polk and Company, Publishers, 1931), 447.

${ }^{40}$ Polk's Morgantown City Directory (Pittsburgh: R.L. Polk and Company, Publishers, 1929-1930), 581; Polk's Morgantown City Directory (Pittsburgh: R.L. Polk and Company, Publishers, 1945), 470.
} 
Although these individuals provided very different services, both engaged closely with the WVU community and relied on student demands for resources, whether books or homemade meals, to make a living. ${ }^{41}$

On a day-to-day basis, Sunnyside's flourishing small business community provided services to residents. On a broader level, it reveals the mixed uses of Sunnyside's landscape. 2157 University Avenue shows families living and working together in one structure and contributing to this culture. Edward Davis passed the tiling company onto his son and it stayed until the mid-twentieth century when it disappeared from city directories, reflecting of a trend that would occur in Sunnyside in the coming decades.

\section{The University Grows: $1945-1960$}

\section{University Avenue}

While small businesses continued to wax and wane throughout the mid-twentieth century, it became clear that Morgantown's most rapidly-growing business was West Virginia University. After World War II, social and cultural forces increased student populations at universities across the United States. The GI Bill of Rights, aiding veterans adjusting to life back in the States, sent enrollment estimates at WVU from 4,500 to 6,000 students in the fall of 1946. In Sunnyside, 2129 University Avenue, home to a GI attending WVU, demonstrates one way that these national changes affected not only universities, but the places their students lived.

Morgantown native Norman Beebe, a Navy veteran in his mid 20s, came to WVU through the GI Bill of Rights. The son of Morgantown glassworkers, Beebe had lived on McLane Avenue in Sunnyside as a child and returned to Morgantown after serving in World War

${ }^{41} 1930$ U.S. Census, Morgantown, Monongalia County, p. 1B-2A, digital image, Ancestrylibrary.com, accessed Feb. 9, 2017; Syrett, In the Company He Keeps, 163. 
II. ${ }^{42}$ He enrolled at a time the University was the largest it had ever been. Between 1946 and 1958, WVU graduated more students than it had in the previous seventy-five years combined. With close proximity to campus, Sunnyside was an attractive place for students to rent. The growing significance of WVU as a center of local activity also shifted town-gown relationships to campus, bringing non-students into the community through events, athletics, and healthcare. ${ }^{43}$ Sunnyside continued to offer amenities for locals and visitors alike, including grocery stores, restaurants, barber shops, and auto shops. ${ }^{44}$

West Virginia veterans, comprising half the student body after World War II, expressed concerns about returning to their state, unsure if its traditional industries would remain strong and stable through demobilization. Their concerns were legitimate, as mining employment decreased by half in every decade beginning in the 1950s. Still, the GI Bill provided access to higher education to the lower classes and instilled a sense of obligation among the WVU community to provide for war heroes at home. As the University grew, it also struggled to accommodate such a high volume of more mature, career-driven students. On a broad level, the University invested in developing Cold War technologies, yet struggled to keep up with elite universities receiving federal funds. On a day-to-day basis, the influx of students put strain on University facilities including classrooms, laboratories, and dormitories. There was also pressure on the University, as well as the city of Morgantown, to provide housing for students when the

${ }^{42} 1930$ US Census. Norman Beebe. http://search.ancestrylibrary.com/cgibin/sse.dll? db=1930usfedcen\&indiv=try\&h=100694546; World War II Young American Patriots, 1941-1945 [database on-line]. Norman Jack Beebe. Accessed April 12, 2016. http://search.ancestrylibrary.com/cgibin $/$ sse. $d 11$ ? indiv $=1 \& \mathrm{db}=$ WWIIpatriots $\& \mathrm{~h}=49979 \& \mathrm{tid}=\& \mathrm{pid}=\&$ usePUB $=$ true \&rhSource $=1788$

${ }^{43}$ Benjamin Fine, "Education in Review: Colleges and College Towns Are Learning To Work Together for Mutual Benefits," New York Times, Jan 10, 1954, ProQuest Historical Newspapers: The New York Times, E9; Lewis, Aspiring to Greatness, 34.

${ }^{44}$ Polk's Morgantown City Directory (Pittsburgh: R.L. Polk and Company, Publishers, 1951), 624-625. 
school day was over. ${ }^{45}$ GIs maintained a "no nonsense approach" to their educations, keeping their distance from younger undergraduates and demanding more space and freedom at school and at home. ${ }^{46}$ These social and cultural changes shifted student housing and the culture of higher education.

Due to the influx of students, Morgantown experienced a local housing crisis, about which President Irvin Stewart expressed concern in 1946: "The University is desperately in need of all living accommodations available in Morgantown or in outlying communities." ${ }^{, 47}$ To compensate, WVU collected military barracks and trailers to provide temporary housing while President Stewart encouraged private funding and construction of dormitories. In the postwar era, one-fourth of students lived in WVU housing, half lived off-campus, and one-tenth were members of Greek organizations. With out-of-state enrollment at WVU hovering between 10\% and $13.5 \%$ in the postwar era, these students, ineligible for campus dormitories, had to find alternative places to live. ${ }^{48}$ Norman Beebe was among the half of students who lived off campus, renting along with his wife, Henriette, at 2129 University. Although he would have been eligible for campus housing as a West Virginian, he was ineligible as a newly married man. More students entered college with spouses in the postwar era, also posing another housing issue. While the overall number of women students dipped in the postwar era, women traveled to college towns with their husbands and were more involved in the workforce than ever before. ${ }^{49}$ This couple, renting a house in a neighborhood increasingly comprised of students, typifies the

\footnotetext{
${ }^{45}$ Lewis, Aspiring to Greatness, 1-4, 32-33, 103; Keeney, "Soldiers and Stereotypes," 203-210; Thelin, A History of American Higher Education, 257-259; Gumprecht, The American College Town, 35.

${ }^{46}$ Helen Lefkowitz Horowitz, Campus Life: Undergraduate Cultures from the End of the Eighteenth Century to the Present (Chicago: The University of Chicago Press, 1987), 168; Gumprecht, The American College Town, 92 .

${ }^{47}$ Doherty and Summers, West Virginia University 192.

${ }^{48}$ Lewis, Aspiring to Greatness, 1-4, 30-37, 101; Gumprecht, The American College Town, 35.

${ }^{49}$ Solomon, In the Company of Educated Women, 189-191.
} 
GI Bill experience. However, like non-students in Sunnyside, their time at 2129 University was short. As many West Virginians had feared, the local economy led students to find work out of state. Beebe first took up a career in industry, working in West Virginia glass factories and then as an engineer in Ohio. ${ }^{50}$

By 1960 , only $25 \%$ of the student body lived in University housing. ${ }^{51}$ As houses in Sunnyside and its surrounding neighborhoods reached fifty years of age, deterioration began to show, especially in a city without zoning ordinances. ${ }^{52}$ In 1960, WVU and local health and safety officials initiated a study to provide "intelligent analysis of the off-campus housing situation," after observing fraternity and sorority housing decline. "If conditions detrimental to health and safety are found in fraternity and sorority houses, over which the University has tacit supervision," the study pondered, "what must conditions be like in 'off-campus' housing, over which the University or city exercise no supervision or control?"53 The study confirmed that the quality of off-campus housing suffered as the University continued to grow.

2129 University Avenue, home to a GI and his wife in the postwar era, reveals multiple examples of national and local change. It shows how policies transforming higher education affected off-campus housing. Although universities have long been responsible for student housing, the housing shortage of the postwar era created an urgency for town-gown communities to solve a practical problem. The resulting actions, coupled with broader trends of deindustrialization and continued University growth, would impact Sunnyside for years to come.

${ }^{50}$ Ironton City Directory for 1960 (Cincinnati: R.L. Polk \& Co., 1960), 13.

${ }^{51}$ F. J. Holter, Student Housing: West Virginia University, Report (Morgantown, WV: May 1960), 6.

52 Pam Kasey, "Sunnyside Up," Morgantown Magazine, May 12, 2016, accessed April 24, 2017, http://www.morgantownmag.com/morgantown/April-May-2016/Sunnyside-Up/.

${ }^{53}$ Holter, Student Housing: West Virginia University, 1. 


\section{The Student Age: 1960 - present \\ 2129 University Avenue}

Built in the late 1890s, 2129 University Avenue had historically been home to a changing population of Morgantown's workers and members of the WVU community. Like its neighboring houses, 2129 University Avenue saw a blend of long-term residents, some of whom were owners or tenants of the house, and short-term residents whose lives adjusted with industry or college life. Its last long-term tenants were Frank and Denise Pierre, Belgian immigrants who worked at the Morgantown Glassworks Guild. However, by the time the Pierres departed in 1961, 2129 University Avenue then became home almost exclusively to WVU students. The departure of the Pierre family and influx of student tenants illustrates a broader shift in Sunnyside housing and the dwindling nature of Morgantown's staple industries. Later, the demolition of 2129 University in 2013 to make way for University Place indicates a new iteration of the student age, in which high-rise apartment complexes were considered more attractive.

Frank and Denise Pierre bought 2129 University Avenue in $1945 .^{54}$ The couple had immigrated to the United States from Belgium to find work in Pennsylvania and West Virginia glass factories. Between 1945 and 1961, several tenants moved through the house. As expected, many of the tenants worked for local industries, including Seneca Glass and a clothing company, or for the University as faculty or staff. ${ }^{55}$ However, by 1960, Morgantown's industries, especially those reliant on fossil fuels, struggled under the pressures of deindustrialization and

\footnotetext{
${ }^{54}$ Monongalia County, West Virginia, Deed Book 370, p. 489; Isaac Hamilton heirs to Frank Pierre, 18 Oct. 1945; Office of the Recorder of Deeds, City of Morgantown.

${ }^{55}$ Polk's Morgantown City Directory (Pittsburgh: R.L. Polk and Company, Publishers, 1947-1948), 185; 1930 U.S. Census, Morgantown, Monongalia County, West Virginia. p. 15A, Frank Pierre, digital image, Ancestrylibrary.com, accessed April 3, 2016. http://search.ancestrylibrary.com/cgi$\mathrm{bin} / \mathrm{sse} . \mathrm{dll} ? \mathrm{db}=1930 \mathrm{usfedcen} \&$ indiv $=$ try $\& \mathrm{~h}=100695033$
} 
globalization. Where the beginning of the twentieth century saw prosperity, the second half saw decades of decline. The Morgantown Chamber of Commerce expressed concern that "ruinous and unfair competition from foreign factories" would be destructive to Morgantown glass industry; all of Morgantown's glass factories closed by the 1990s. ${ }^{56}$ Statewide, the employment of West Virginia coal miners cut in half with each passing decade, sending one-quarter of the state's population into an economic depression in the 1960 s. $^{57}$

In turn, Morgantown's most lucrative industry became its university, which expanded and diversified in the mid-twentieth century. Morgantown, like other college towns of this time, experienced a shift in the "power balance" of the local economy that emphasized the University as a significant economic driver for the community ${ }^{58} \mathrm{WVU}$ sought new space to expand. The Evansdale and Medical campuses opened in the 1960s, splitting the University between the old and new. In Sunnyside, the Downtown campus's residential neighbor, also began to change.

Sunnyside, influenced by variety of socioeconomic factors, transformed into a student neighborhood. As deindustrialization diminished the number of workers and families in Sunnyside, landlords took advantage of the housing stock and lucrative student rental market. Students found Sunnyside, within short walking distance of the Downtown campus, a convenient and inexpensive place to live. Whereas University-owned dormitories cost between $\$ 11$ and $\$ 13$

\footnotetext{
${ }^{56}$ Letter to Edgar B. Brossard, Chairman of the United States Tariff Commission. January 25, 1954. From James E. Coombs, President of Morgantown's Chamber of Commerce, folder WV / Morgantown Glass Industry History, Personalities c. 1906-1996, Coll. 4184, Delores Fleming papers, West Virginia and Regional History Center, West Virginia University.

${ }_{58}^{57}$ Lewis, Aspiring to Greatness, 4.

${ }^{58}$ Gordon Lafer, "Land and Labor in the Post-Industrial University Town: Remaking Social Geography," Political Geography Vol. 22 (2003): 90-91; Ray Bromley, "On and Off Campus: Colleges and Universities and Local Stakeholders," Planning, Practice \& Research. Vol. 21, No. 1 (February 2006): 3; Barry Bluestone and Bennett Harrison, The Deindustrialization of America: Plant Closings, Community Abandonment, and the Dismantling of Basic Industry, 6-10.
} 
per week, off-campus housing cost anywhere from $\$ 5$ to $\$ 10 .{ }^{59}$ Beginning in the 1960 s, Sunnyside experienced "studentification," the replacement of one, more vulnerable population with a student population, which ultimately transformed the neighborhood culture. ${ }^{60}$ As the decades went on, this housing stock declined in quality. The neighborhood, as one student noted, was comprised of "basically 100-year-old houses broken into apartments." Students expressed feeling "exploited by landlords" and noted that there was "absolutely no prompt service on repairs." 61

WVU's expansion, characterized by one student as "growing pains," contributed to broader student housing issues that had challenged Morgantown since the postwar era. ${ }^{62}$ To remedy the housing shortage, WVU constructed new dormitories and apartments, while simultaneously encouraging private developers to build. Zoning ordinances in Morgantown designated Sunnyside as an R2 (residential-duplex) district, allowing landlords to convert singlefamily homes into duplexes. Although the R2 status also incentivized landlords to buy up houses in Sunnyside, it did not allow for large apartment buildings to be constructed. The University and private developers, therefore, acquired variances that allowed them to skirt around Morgantown zoning ordinances. Summit Hall, a ten-story University dormitory, opened in Sunnyside in 1966

\footnotetext{
${ }^{59}$ Sherrie Moran and Charlie Cumpston, "Lack of 'Good' Housing Not Critical," The Daily Athenaeum, September 23, 1965, 1, 4; Susan Jones, "Sunnyside district 'just isn't what it used to be," The Daily Athenaeum, November 16, 1982, 6. This process of landlords buying out single-family homes is also described in other college towns. See Gumprecht, The American College Town, 93.

${ }^{60}$ Joanna Sage, Darren Smith, and Phil Hubbard, "The Diverse Geographies of Studentification: Living Alongside People Not Like Us," Housing Studies, Vol. 27, No. 8 (November 2012): pp. 1057-1076; Graham Pickren, "Where Can I Build My Student Housing? The Politics of Studentification in Athens-Clarke County, Georgia." Southeastern Geographer, Vol. 52 No. 2 (Summer 2012): 116-119. Studentification is often considered a form of gentrification because, in many cases, wealthier students replace lower-income, ethnic families and sleek, modern homes replace old ones. In Sunnyside, however, housing stock diminished in quality and turned then neighborhood into an unsightly "student ghetto."

${ }^{61}$ Cletis Pride and David Drew, As Others See Us: Three Key Publics Assess West Virginia University; Final Report of a Study Conducted for the West Virginia University Foundation, Inc. (Morgantown: West Virginia University, 1972), 100.

62 Joyce Breach, "One Thing at a Time: Campus Chaos Drowns Desire," The Daily Athenaeum, September 23, 1965, 2.
} 
and housed nearly 600 students. In total, nine large residence halls were built around Morgantown in this time, alleviating the housing shortage. Instead, the WVU community faced two issues related to housing, one new and one longstanding. Against the University president's aspirations, private developers built too quickly and created a housing surplus. ${ }^{63}$ Additionally, the WVU community became increasingly concerned about the quality of traditional singlefamily housing stock that Morgantown tenants had relied on for decades. In 1965, between 12\% and $25 \%$ of the 8,000 students living off-campus struggled to find safe and satisfactory housing. This was a "sensitive subject" for the University Housing Office. If all inadequate houses were shuttered, they rationalized, thousands of students "would be unable to attend the University." Although they could conduct inspections of heating systems, fire escapes, and electrical wiring, the University Housing Office understood that responsibility to check standards on an incalculable number of off-campus houses fell to the landlords, the city, or the state, straining town-gown relations. ${ }^{64}$

Sunnyside houses like 2129 University reflect the housing shift of this time. Around 1961, the glassworkers, Frank and Denise Pierre, left 2129 University and deeded the house to George Batlas. Unlike previous owners, Batlas did not live in the house. He rented it to a constantly moving population of students, whose names appeared and disappeared in the city directories as quickly as their college years passed. They included students such as 1971 graduate Sharon O’Kelly, a drama major and National Collegiate Players member from Dunbar, West Virginia, who shared the house with three other students. ${ }^{65}$ Houses surrounding 2129

\footnotetext{
${ }^{63}$ Lewis, Aspiring to Greatness, 187-189; Kasey, "Sunnyside Up;" Campus Neighborhoods Revitalization Corporation. Annual Report 2015 (Morgantown, WV: Campus Neighborhoods Revitalization Corporation, 2015) 89, accessed April 24, 2017. http://sunnysideupwv.org/images/page_001.pdf

${ }^{64}$ Sherrie Moran and Charlie Cumpston, "Lack of 'Good' Housing Not Critical," The Daily Athenaeum, September 23, 1965, 1, 4; John Burch, "Zoning Cause of Housing Troubles," The Daily Athenaeum, October 14, 1965.

${ }^{65}$ Monticola (1971), 235.
} 
University also attracted more students. Landlords purchased these houses as soon as they went on the market and used the R2 zoning ordinance to fill the houses with as many students as possible. City directories likely do not include all of those who rented these houses. However, they do show that residents in Sunnyside were constantly in flux. By 1980, of the twenty-seven residents living in the twelve structures in the 2100 block, nineteen of them were considered "new residents" and their names marked with a star in the city directory. ${ }^{66}$

In 1979, 2129 University Avenue opened its doors as Mutt's Sunnyside Pub. This beloved bar signifies student influence over the neighborhood's businesses and social activities. Morgantown historically has been home to drinking establishments; among the first businesses downtown were taverns and breweries, which served immigrants heading westward. As Morgantown developed into a college town, an enthusiastic market of students kept taverns in business throughout the city. Drinking had long been associated with student culture, and Sunnyside's identity as a student center attracted more bars, pubs, and taverns to the neighborhood. $^{67}$

Opened in 1935, Mutt's was situated on Beechurst Avenue owned by Mottie "Mutt" Pavone, the son of Italian immigrants, and his wife Rose Poropatt Pavone, a Yugoslavian immigrant. ${ }^{68}$ After Mottie's death in 1955 at age 51, Rose continued to operate the business independently. ${ }^{69}$ Their son, Mottie, who also went by the nickname "Mutt," worked in real

${ }^{66}$ Polk's Morgantown City Directory (Pittsburgh: R.L. Polk and Company, Publishers, 1980), 173.

${ }^{67}$ Callahan, History of the Making of Morgantown, 85, 113, 129; John J. Sloan III and Bonnie S. Fisher, The Dark Side of the Ivory Tower: Campus Crime as a Social Problem (Cambridge: Cambridge University Press, 2011), 10-16.

68 “Rose E. Poropatt Pavone," Find a Grave, accessed April 5, 2016. http://www.findagrave.com/cgibin/fg.cgi?page=gr\&GRid=20073249; 1930 U.S. Census, Star, Monongalia County, West Virginia. p. 2A, Mottie Pavone, digital image, Ancestrylibrary.com, accessed April 5, 2016. http://search.ancestrylibrary.com/cgibin/sse.dll? db=1930usfedcen\&indiv $=$ try $\& h=100703016$

69 "Rose E. Poropatt Pavone," Find a Grave. 
estate, owning Hampton North Mobile Home Park and Pavone Rentals. ${ }^{70}$ He acquired 2129 University in 1972 and continued renting the property to students. ${ }^{71}$ In 1979, a fire destroyed Mutt's original location on Beechurst Avenue. The Pavones found a new home for Mutt's in 2129 University. Rose turned over operations to her son, who rented the apartment above the pub. $^{72}$

By the 1980 s, only $20 \%$ of students lived in campus housing. ${ }^{73}$ Sunnyside offered cheap rental houses, pubs and other social spaces, and lacked the University oversight that attempted to curb student parties. At the same time Sunnyside transitioned into a student neighborhood, WVU earned its reputation as a party school. Students considered Sunnyside "without a doubt, the most recognizable place for drinking around the University." "74 Just about any night of the week, students headed to Sunnyside's bars and house parties to "commemorate their accomplishments," even if that meant simply getting through a day of classes. ${ }^{75}$ One student writer recalled, "A new student may not know where his classes are, but he can find all the bars in Sunnyside.. ${ }^{76}$ Mutt's was known for its "all-you-can-eat" spaghetti lunches on Saturdays that served students facing shoestring budgets and the fallout of indulgent drinking. ${ }^{77}$ For three decades, Mutt's was an important student institution.

Beginning in the 1970s, students in Sunnyside developed traditions such as the Grant Avenue block parties and couch burnings, often held after WVU football games. However, the

\footnotetext{
70 “In Loving Memory of Mottie 'Mutt' William Pavone," Memorial Networks, Accessed April 3, 2016 http://www.fredjenkinsfuneralhome.com/memsol.cgi?user_id=1578871

${ }^{71}$ Monongalia County, West Virginia, Deed Book 724, p. 48; George Batlas to Mottie Pavone, July 1972; Office of the Recorder of Deeds, City of Morgantown.

72 "Rose E. Poropatt Pavone," Find a Grave.

${ }^{73}$ Lewis, Aspiring to Greatness, 305-306.

${ }^{74}$ Karen Garvin, "Activity Thrives After Hours," Monticola (1983) 16-17.

${ }_{76}$ Terri Weimer, "Any Occasion Makes Way for a Celebration," Monticola (1983) 42-43.

${ }^{76}$ Garvin, "Activity Thrives After Hours," 16-17.

${ }^{77}$ Nettie Fowler, "Eat it Up: Command the Genie of Extravagance as Student Hunger," Monticola (1985), 39.
} 
fun, when coupled with alcohol abuse, was also met with instances of rowdiness, violence, vandalism, and sometimes the injury or death of students due to drunk driving or alcohol poisoning. Sunnyside, as often the setting of these events, was targeted as the problem. A number of bars in Sunnyside, including Mutt's, claimed the city had a "Prohibition mentality" that put neighborhood under scrutiny. Although they acquired state liquor licenses, a city zoning ordinance forbade Sunnyside bars from selling liquor in a beer-zoned area, which the bars publicly violated and challenged. ${ }^{78}$ Partying and a student culture centered on drinking changed not only 2129 University, but the cultural landscape of Sunnyside in the late twentieth century.

As Sunnyside moved into the twenty-first century, WVU and Morgantown locals envisioned a more inviting, attractive, and safer place for students to live, which would fulfill broad student interests in $\mathrm{d}$ the amenities, privacy, and freedoms off-campus housing offered. ${ }^{79}$ The 2100 block of Sunnyside changed dramatically beginning October 23, 2012, when West Virginia University's Board of Governors approved acquisition of a five-acre plot of Sunnyside for $\$ 14.6$ million. The initiative was part of a student housing master plan approved in September of that year to update, expand, and diversify housing options for patrons of WVU. It considered student housing a barrier to WVU's 2020 strategic plan and a limitation to its ability to attract "the best and brightest students." The plan called for new facilities on the Downtown Campus to hold 975 additional beds, focusing on retaining first- and second-year students. ${ }^{80}$ On

\footnotetext{
${ }^{78}$ Sharman Peters, "No liquor in Sunnyside, court injunction filed," The Daily Athenaeum, August 25, 1982, 1-2; Schuyler Kropf, "Foxfire named in zoning suit for selling liquor in Sunnyside," The Daily Athenaeum, September 25, 1985, 1, 3 .

${ }^{79}$ Doherty and Summers, West Virginia University, 327-328; Lewis, Aspiring to Greatness, 304-306, 486489; West Virginia University Facilities Planning, West Virginia University: Main Campus Student Housing Master Plan - 2012, 7 .

${ }^{80}$ Facilities Planning. Main Campus Student Housing Master Plan (Morgantown: West Virginia University, 2012), 4, 11, 17, last updated September 28, 2012, accessed April 3, 2016. http://facilitiesplanning.wvu.edu/files/d/25ad7fe5-b23c-432b-9f1b-00b3cd531b12/student-housing-mater-plan2012.pdf
} 
October 26, 2012, West Virginia University entered into a public-private partnership with Paradigm Development Group, LLC, to develop a \$70 million mixed-use residential and retail complex on the 2100 block of Sunnyside, bound by University Avenue, Grant Avenue, Third Street, and Houston Drive.

Unlike earlier periods, WVU has played an increasingly active role in Sunnyside's student housing in the past decade. The University Place project reflects WVU's trend toward property acquisition and connections to outside organizations to address issues in Sunnyside, which had been designated a "blighted" neighborhood in $2003 .{ }^{81}$ Earlier in 2012 , WVU purchased more than 25 acres of property and bankrupt apartment complexes around Morgantown. These purchases helped accomplish goals set in the 2020 master plan, which called for improvement of "campus facilities and services such as residential halls." 82 The 2100 block of Sunnyside had not been a "campus facility" until it was purchased in October 2012, indicating that the University wished to extend "campus" further into Sunnyside. To help with their increasing involvement in Sunnyside properties, WVU forged relationships with for-profit and nonprofit organizations in Morgantown. Paradigm Development Group, LLC, established by local engineers and contractors in February 2012, partnered with WVU to develop, finance, and manage University Place. ${ }^{83}$ The Campus Neighborhood Revitalization Corporation, also known as Sunnyside Up, began spearheading broader transformation efforts in Sunnyside in 2002. Their Comprehensive Revitalization Plan aimed to diversify Sunnyside’s properties, improve infrastructure, and create green spaces. Additionally, Sunnyside Up was instrumental in

\footnotetext{
${ }^{81}$ Environmental Planning and Design, LLC, Sunnyside Up: Comprehensive Revitalization Plan, Volume 1 (Morgantown: Campus Neighborhoods Revitalization Corporation, Fall 2004), iii.

${ }^{82}$ West Virginia University, WVU 2020: Strategic Plan for the Future (Morgantown: West Virginia University), accessed April 24, 2017, http://strategicplan.wvu.edu/r/download/90223

${ }^{83}$ Dave Boucher, "Private group assuming all costs on WVU-Sunnyside project," Charleston Gazette-Mail, October 29, 2012, accessed April 24, 2017, http://www.wvgazettemail.com/News/201210280165
} 
establishing a Tax Increment Financing (TIF) district in Sunnyside in 2008, which would help redesign streetscapes and vary housing options. ${ }^{84}$

Both Paradigm and Sunnyside Up advocated for a shift Sunnyside's demographics away from undergraduates to include faculty, professionals, and young families. "University Place," a representative of Paradigm said, "will expand student housing and retail options in Sunnyside and will revitalize an unattractive dilapidated area into a beautiful, safe and affordable place for students, faculty, staff and citizens to live, work and shop." ${ }^{\prime 85}$ Similarly, Sunnyside Up argued that diversifying the neighborhood demographics would realize "Sunnyside's vibrancy." "The types and intensity of activities that could exist within the area are seemingly endless," the plan noted. ${ }^{86}$ The fruits of these efforts could also be calculated in more than social experiences. "The difference between those 30 homes that were there and the $\$ 70$ million facility is millions of dollars," Frank Scafella, executive director of Sunnyside Up and former mayor of Morgantown, said of this change. ${ }^{87}$ These organizations, in partnership with WVU, demonstrated powerful new visions for Sunnyside's future.

\footnotetext{
${ }^{84}$ Environmental Planning and Design, LLC, Sunnyside Up: Comprehensive Revitalization Plan, Volume 1, iii, v; Campus Neighborhoods Revitalization Corporation, Proposed TIF Project for Sunnyside, Phase II, 2013-14 (Morgantown, WV: Campus Neighborhoods Revitalization Corporation, June 2013), accessed April 24, 2017, http://sunnysideupwv.org/images/CNRC--TIF_Project,_Phase_II_2013.pdf; Campus Neighborhoods Revitalization Corporation, Sunnyside TIF Property Database (Morgantown, WV: Campus Neighborhoods Revitalization Corporation, 2015), accessed April 24, 2017, http://sunnysideupwv.org/images/Sunnyside_TIF_Property_Databate.pdf.

${ }^{85}$ University Relations/News, "WVU engages in public-private partnership to develop a $\$ 70$ million mixed use residential and retail complex in Sunnyside," WVU Today, Oct. 26, 2012, $\mathrm{http}: / /$ wvutoday.wvu.edu/n/2012/10/26/wvu-engages-in-public-private-partnership-to-develop-a-70-million-mixeduse-residential-and-retail-complex-in-sunnyside

${ }^{86}$ Environmental Planning and Design, LLC, Sunnyside Up: Comprehensive Revitalization Plan, Volume 1, 11.

${ }^{87}$ Emily Leslie, "What happened to Sunnyside? Where did it all go?" The Daily Athenaeum, May 12, 2015, accessed April 24, 2017, http://www.thedaonline.com/news/article_fbefe0fe-f382-11e4-b08d-0fd201495fde.html.
} 
Just as it presented opportunity to landlords decades before, Sunnyside presented an opportunity for WVU. On October 26, 2012, Mottie Pavone signed 2129 University over to Paradigm Development as part of the company's group purchase. ${ }^{88}$

Despite all University Place had to offer, not all students warmly embraced the change. Many felt the loss of these homes on practical and emotional levels. The Daily Athenaeum, WVU's student paper, published front-page articles covering student reactions to the proposed complex. In particular, reporters spoke to student tenants living within the future footprint of University Place, who were told to move out by December. Student tenants felt "shocked" and "inconvenienced" by the news of eviction in the middle of the school year. They also felt punished for Sunnyside's stereotypes. One two-year resident said, "The people that come here and are disruptive don't even live on Grant [Avenue]...It's the people from the rest of the University that will come here and start problems. There's nothing wrong with Sunnyside.” ${ }^{\circledR 9}$ Students also pointed to an intangible loss that they felt University Place would bring: the "college experience" in Sunnyside. "I just like walking outside and seeing [my friends]," one student shared. 'I don't want to live somewhere where I don't know anybody and I have to start over." 90 Tenants of house on Grant Avenue painted their thoughts on a sheet hanging from the porch, perhaps best capturing the sentiment in Sunnyside: "Country roads, take me home, oh wait...we are homeless." 91 Rewriting the West Virginia state theme song, "Country Roads" by

\footnotetext{
${ }^{88}$ Monongalia County, West Virginia, Deed Book 1468, p. 383; Mottie Pavone to Paradigm Development Group, LLC, October 26, 2012; Office of the Recorder of Deeds, City of Morgantown.

${ }^{89}$ Carlee Lammers, 'Students react to news of University's $\$ 70$ million plan for 'University Place' in Sunnyside," The Daily Athenaeum, October 29, 2012, accessed April 24, 2017, http://www.thedaonline.com/article_075625f2-7fa4-5894-8fcd-83bc1804ac05.html.

${ }^{90}$ Carlee Lammers, "Students react to news of University's $\$ 70$ million plan for 'University Place' in Sunnyside," The Daily Athenaeum, October 29, 2012, accessed April 24, 2017, http://www.thedaonline.com/article_075625f2-7fa4-5894-8fcd-83bc1804ac05.html.

${ }^{91}$ Emily Leslie, "What happened to Sunnyside? Where did it all go?" The Daily Athenaeum, May 12, 2015, accessed April 24, 2017, http://www.thedaonline.com/news/article_fbefe0fe-f382-11e4-b08d-0fd201495fde.html.
} 
John Denver, these student tenants made an emotional appeal that encompassed the loss of their houses as well as their sense of place.

Students turned to the digital world to express their thoughts on the loss of Mutt's and general changes in Sunnyside. On October 22, 2012, the day University Place was announced, students reacted on Twitter with hashtags such as \#SaveMutts, \#SaveSunnyside, and \#RIPSunnyside. They immediately used these hashtags to express feelings of frustration, sadness, and resentment. Many blamed the University for participating in the rapid redevelopment of Sunnyside. George Petroplus tweeted, "Would be very disappointing to see WVU potentially close Mutt's as part of Sunnyside acquisition."92 Zach Ackerman tweeted, "WVU needs to realize that keeping Mutts open is more important not building campus housing. No one wants more university housing. ${ }^{, 93}$ Most students lamented the pending loss of a favorite hangout. The \#SaveMutts hashtag began trending on Twitter worldwide by the end of the day, one student joking, "No one takes their drinking as seriously as WVU."94

Students also used the \#SaveSunnyside hashtag to express the loss of their homes.

Samantha Wilson, who lived in one of the houses, reacted to the news, "Thanks \#WVU for kicking me out of my house so you can destroy the best street on campus."95 Jessica Mazelon tweeted to The Daily Athenaeum: "Its [sic] absolutely awful to force students out of their homes mid-year and make them pay more for rent. ${ }^{, 96}$ While most tweets criticized the University, a handful of Twitter users praised the effort to restore what they felt was a run-down area of

\footnotetext{
${ }^{92}$ George Petroplus, Twitter post, October 22, 2012, 4:14pm https://twitter.com/GPetroplus/status/260474352011714560

${ }^{93}$ Zach Ackerman, Twitter post, October 22, 2012, 3:45pm https://twitter.com/zackerman22/status/260466918044094465

${ }^{94}$ David, Twitter post, October 22, 2012, 5:34 https://twitter.com/DavidYDG/status/260494477033086976

${ }^{95}$ Samantha Wilson, Twitter post, October 26, 2012, 4:39 https://twitter.com/samwilson15/status/261930163674165248

96 Jess Mazelon, Twitter post, October 26, 2012, 2:13 https://twitter.com/JessMazelonWVU/status/261893395943915520
} 
Morgantown. Gregg Thomas tweeted, "WVU re-developing the Sunnyside area into something useful and beneficial for the university should be applauded."97

The evening and early morning of January 28 and 29, 2013, the last day Mutt's was open, students took to Twitter again with a flurry of bittersweet tweets. They wrote of challenging one another to consume the pub's remaining alcohol and group sing-alongs to Billy Joel's "Piano Man." 98 Their emotions and need to document these memories reflect their connections to Mutt's as a place in the Sunnyside community. On April 4, 2013, the building was demolished.

Mutt's returned to Beechurst Avenue when it reopened in the summer of 2014, and the owners and patrons have endeavored to "recreate" the atmosphere that was once on University Avenue, instilling a casual atmosphere and hanging "the same pictures on the walls." located on one of Morgantown's busiest city streets, the pub sits among a handful of small businesses and commercial chains, rather than in a residential area with yards and streets open for block parties.

University Place opened in 2014, offering furnished one- to three-bedroom apartments with hardwood-style floors, granite kitchen countertops, private bathrooms, select household appliances, and flat-screen televisions. On the first floor, it also offered popular commercial franchises like a 24/7 Sheetz. ${ }^{100}$ On one level, their efforts fulfilled plans to diversify

\footnotetext{
${ }^{97}$ Gregg Thomas, Twitter post, October 26, 2012, 7:18pm https://twitter.com/gregg_thomas/status/261970145109483521

${ }^{98}$ Rima Cario, Twitter post, January 25, 2013, 10:25pm https://twitter.com/RimaCario90/status/295009501373943809; Matthew Weston, Twitter post, January 28, 2013, 7:11 pm https://twitter.com/mweston11/status/296047891775111168

${ }^{99}$ Summer Ratcliff, "Mutt's reopens after a disappointing close in 2013," The Daily Athenaeum, June 3, 2014, accessed April 24, 2017, http://www.thedaonline.com/news/article_bf2c7ede-eb95-11e3-9b6a$0017 \mathrm{a} 43 \mathrm{~b} 2370 . \mathrm{html}$.

${ }^{100}$ Madeleine Hall, "Sunnyside Construction still affecting UPlace residents," The Daily Athenaeum, January 29, 2016, accessed April 24, 2017, http://www.thedaonline.com/special_sections/article_c322751c-c64911e5-8109-e342bc32f65c.html; “Amenities,” University Place, West Virginia University, last modified April 26, 2016, accessed April 27, 2017, http://uplace.wvu.edu/amenities.
} 
Sunnyside's land use and provide housing and amenities to a variety of tenants. On another level, these changes challenged students, whether they embraced or rejected University Place, to reconsider their relationships with the neighborhood. As one advertisement on the University Place Facebook page proclaimed: "Less worries - WVU is your landlord."101

\section{An Age of Revitalization}

These three structures on University Avenue in Sunnyside tell a story about the neighborhood's physical and social shifts. Built for local industries, these structures later became central to student living and traditions. The physical houses, along with the multitude of people who resided in them, comprise a cultural landscape that carried varied meanings and memories to the people who have called it home. Through snapshots of individual lives, a rich image of workers and students illustrate how Sunnyside's residents lived. By the late twentieth century, students claimed Sunnyside as the setting of their fleeting college years. Their time-sensitive stay presented changes and challenges to the neighborhood, especially in the late twentieth century and into the new millennium. Like its student population, Sunnyside is also transient, its built environment and social activities constantly shifting with new waves of residents and ways of life. $^{102}$

The demolition of these structures, whether residential or commercial, transformed not only Sunnyside's appearance, but the way students interacted with the landscape. The difference between a two- or three-story house compared to an eight-story, 300,000 square foot apartment complex extends beyond numerical measurements. Both building types present different ways of

\footnotetext{
${ }^{101}$ University Place at Sunnyside, Facebook.com, July 8, 2014, accessed April 27, 2017, https://www.facebook.com/UniversityPlaceAtSunnyside/photos/a.319931111483167.1073741829.29123424435285 4/435075613302049/?type=3\&theater.

102 Cowie and Heathcott, Beyond the Ruins, 5.
} 
living. For some students, University Place, despite its top-notch amenities and convenience, is a more commercialized, less authentic form of student housing. The structures that existed prior to University Place's construction conveyed Sunnyside's traditional appearance where parties took place. Even if unsightly, these structures and the activities that occurred around them were meaningful components to Sunnyside's cultural landscape.

The past 120 years show both symbolic and legal forms of ownership in Sunnyside. This is evident in the various tenants, homeowners, businesses, organizations, and traditions that have lived in the neighborhood over time. By building University Place, WVU claimed a sense of ownership over Sunnyside properties and culture. They reimagined Sunnyside's physical landscape and student living experiences. Their Facebook page, entitled "University Place at Sunnyside," reflects marketing and branding strategies found in small businesses of the 1920s and 1930s, in which the word "Sunnyside" was integrated into business names. In the context of revitalization, projects adopt "historic" names to legitimize their place in a neighborhood and on the timeline of local narratives. ${ }^{103}$ University Place, though physically anchored in a traditionally student-centered space, is a radically different embodiment of student wants and needs. Its subtle adoption of the name "Sunnyside" shows how it is setting the neighborhood on a new course for the future.

The success of such revitalization efforts in Sunnyside become more controversial considering an October 2016 expose from The Daily Athenaeum, which found that University Place remained 55\% vacant and \$2.7 million in debt. This housing surplus in Morgantown, contrasting housing shortages at other major universities, complicates discussions of future

${ }^{103}$ Alison Isenberg, Downtown America: A History of the Place and the People Who Made It (Chicago: University of Chicago Press, 2004), 311; John A. Jakle and David Wilson, Derelict Landscapes: Derelict Landscapes: The Wasting of America's Built Environment (Savage, MD: Rowman and Littlefield, 1992), 265-268, $278-281$. 
developments in Sunnyside. ${ }^{104}$ Responses to the current housing surplus echo those in the mid1960s, when another housing surplus occurred in response to the postwar University expansion. Students writing about housing issues have expressed similar apprehensions even with fifty years span between their conversations. John Burch, writing in 1965, worried about the effects of urban sprawl on students: "The futures of Morgantown and of WVU are ultimately tied together. If Morgantown becomes an ugly, ill-planned city, the University will be sure to lose a lot of student enthusiasm and morale." ${ }^{\prime 05}$ In 2014, David Schlake also advocated for "a more studentcentric mindset," arguing that although University Place attempted to revitalize Sunnyside, the drive to build and profit overshadowed student experience. University Place seemed to check off everything on contemporary student wish lists, though for students like Schlake, the demolition of traditional housing and threat to small businesses compromised Morgantown's "history, tradition, and its own taste in culture." "It shouldn't only produce revenue for the future," Schlake said of University Place, "but also produce a better life on campus for students in the long run, while keeping the Morgantown culture that has stuck around for so long."106 These conversations are sure to continue for years to come, as WVU plans to increase enrollment from 28,000 students in 2016 to 40,000 in the coming years. ${ }^{107}$ Sunnyside Up executive director, Frank Scafella, described the 2100 block's new appearance as Sunnyside "rising like the

${ }^{104}$ Caity Coyne, "University real estate complicates housing market," The Daily Athenaeum, Oct. 19, 2016, 3; John Mark Shaver, "Store owners speak out about corporate businesses coming to Morgantown, Sheetz' influence," The Daily Athenaeum, November 6, 2015, accessed March 27, 2017, http://www.thedaonline.com/news/article_833f899e-844a-11e5-b049-6b1a3bfa25c5.html.

${ }^{105}$ John Burch, "Zoning Cause of Housing Troubles," The Daily Athenaeum, October 14, 1965.

${ }^{106}$ David Schlake, "University Place: the wrong move for WVU," The Daily Athenaeum, April 17, 2014, http://www.thedaonline.com/opinion/article_2a4c02c4-c5fe-11e3-af25-0017a43b2370.html.

107 Jake Jarvis, "Gee talks budget cuts, state legislature and WVU expansion," The Daily Athenaeum, February 23, 2016, http://www.thedaonline.com/news/article_2c013608-da00-11e5-9fde-f3e7f1ddf016.html; E. Gordon Gee, "Enrollment, quality of students continues to increase at WVU," Office of the President, published in The Dominion Post, May 22, 2016, http://presidentgee.wvu.edu/speeches/enrollment-quality-of-students-continuesto-increase-at-wvu. 
Phoenix...from the ashes of its predecessor." ${ }^{, 108}$ For some, the phoenix is a welcome change after decades of blight. For others, it suggests that the University is commercializing and controlling a neighborhood that previous students developed organically.

Sunnyside remains a contentious cultural landscape. As Sunnyside undergoes physical transformations, it reflects the idea that cultural landscapes exist within broader processes, such as deindustrialization and studentification. It demonstrates the administrative power universities wield over a college town, as well as their efforts to collaborate with non-academic community stakeholders. ${ }^{109}$ Through microhistory, the nuances of a cultural landscape emerge.

${ }^{108}$ Campus Neighborhoods Revitalization Corporation, From Mutt's Place to University Place: Annual Report 2013-2014 (Morgantown, WV: Campus Neighborhoods Revitalization Corporation, Feb. 2014): 12, accessed April 4, 2016. http://sunnysideupwv.org/images/CNRC--2014_Annual_Report_July_10.pdf

${ }^{109}$ Cowie and Heathcott, Beyond the Ruins, 5-6; Bromley, "On and Off Campus," 10-13. 


\section{CHAPTER TWO}

\section{Students, the University, and In Loco Parentis in Off-Campus Housing}

Contemporary revitalization in Sunnyside has stirred a lot of conversation among WVU students and administrators. One of the core issues both groups discuss is housing, an essential resource for students. With public-private partnerships between WVU and outside organizations, the lines between on-campus and off-campus housing are increasingly blurred. Sunnyside, as an older student neighborhood, often sits at the center of these conversations. As more Universityowned complexes replace traditional homes, not only are the physical and cultural landscapes of Sunnyside changing, but so are relationships between students and the University. Examining the history of students, off-campus housing, and the University sheds light on these relationships and the distinct student culture that developed in Sunnyside.

Off-campus housing reflects social and cultural shifts in higher education that occurred in the mid-twentieth century. Universities responded to the pressures of housing shortages and increased enrollments put on facilities. ${ }^{1}$ Moreover, universities came to terms with broader changes in student culture that challenged traditional housing policies. As universities, including WVU, shifted the responsibility of housing to private developers and landlords, some of whom saw success while others did not, they also freed students from the doctrine of in loco parentis. A Latin term for "in place of the parent," in loco parentis was a method of establishing studentuniversity relationships. In this study, in loco parentis is both a historical concept and framework for understanding these relationships at WVU.

\footnotetext{
${ }^{1}$ F. J. Holter, Student Housing: West Virginia University, Report (Morgantown, WV: May 1960), 6; Lewis, Aspiring to Greatness, 32-34.
} 
Until the mid-twentieth century, higher education supported policies that legally and symbolically oriented universities and students in a parent-child relationship. Under in loco parentis, universities established on-campus dormitories, regulations on student behavior and dress, and administrative deans to oversee students' day-to-day activities. The grip of parental oversight loosened in the postwar period as universities filled with veterans, tripling the number of young Americans in college. Veterans rebuilding their lives after war sought a relaxed and career-oriented atmosphere that respected their worldly life experience. ${ }^{2}$ The 1950 s saw a rise in athletics and the appearance of college student archetypes: the successful "Joe College" and doting "Betty Co-ed," college sweethearts who graduated to pursue the American Dream. ${ }^{3}$ By the 1960s, colleges diversified and desegregated, bringing together students both of like minds and different backgrounds. Empowered by a culture of revolution, students of the 1960s began dismantling the in loco parentis policies that they felt impeded their individual freedoms.

Student conduct policies serve one or more of the following purposes: to prevent harm, to prevent an undermining of academic values, and to foster a sense of "moral community and mutual responsibility." Through this framework, campus communities structure arguments either for or against policies regulating behavior. These policies set standards as well as a tone for student-university relationships. Still, the minutiae of behavior, the undulating of student populations, and the changing approaches to higher education complicate how these policies are enforced and whether they are relevant. ${ }^{4}$

By examining the history of in loco parentis beyond the legal and political realm, a complicated image of student culture emerges. Students at WVU, in critiquing in loco parentis

\footnotetext{
${ }^{2}$ Gumprecht, The American College Town, 33-36.

${ }^{3}$ Thelin, A History of American Higher Education, 297.

${ }^{4}$ David Hoekema, Campus Rules and Moral Community: In Place of in Loco Parentis (Lanham, Md.: Rowman \& Littlefield, 1994) 27, 134-138.
} 
policies, grappled with fundamental questions of identity and freedom. They wondered, individually and collectively, how they should be treated as newly-minted adults and how that status should shape their everyday lives. These questions remained relevant even after formal in loco parentis policies disappeared. This is especially true in off-campus housing, in which students are freer to make decisions, and especially in Sunnyside, a place where students have implemented some of these decisions. When access to these opportunities are threatened, by poor housing conditions or revitalization efforts, students have varied reactions that are captured in historical records. This chapter outlines student perspectives on in loco parentis policies of the 1960s and the relationships between students and the University after these policies disappeared. It also explores student demands for freedom and the housing opportunities they felt they deserved.

\section{In Loco Parentis at West Virginia University}

By the mid-twentieth century, American universities opened to the masses, transforming their cultural and social significance. Young people pursued higher education with higher expectations for what their time as a student should look like. Branching out on their own, usually for the first time, students began to form ideas separate from their parents about how they should live and participate in society. ${ }^{5}$ By the 1960s, Mountaineers questioned the necessity of traditional in loco parentis policies. They expressed in writing and through activism how they

\footnotetext{
${ }^{5}$ Thelin, A History of American Higher Education, 260-271; Gumprecht, The American College Town, 3537; Babette Faehmel, College Women in the Nuclear Age: Cultural Literacy and Female Identity, $1940-1960$ (New Brunswick, NJ: Rutgers University Press, 2012), 43; Horowitz, Campus Life, 228; Ray Bromley, "On and Off Campus: Colleges and Universities and Local Stakeholders," Planning, Practice \& Research, Vol. 21, No. 1 (February 2006): 1-2, 5-6.
} 
felt stifled by University regulations and wanted to make decisions that impacted their lives individually and the policies in place at WVU. ${ }^{6}$

Among these regulations were housing policies. Traditionally, unmarried male and female students not residing with relatives were required to live in University housing. ${ }^{7}$ Outside of their residences, a student's social life was "carefully planned and supervised" to offer "a wholesome type of pleasure without curbing the institution's main purpose - education of the student." ${ }^{\circ}$ Students' abilities to choose their own housing became a pertinent conversation topic in the late 1960s and beyond, especially as WVU in the recent past faced housing shortages brought on by the GI Bill, overall increases in enrollment, and zoning issues. ${ }^{9}$ By examining broader conversations on in loco parentis policies, a common theme emerges. Students perceived these policies as hindering their ability to make adult decisions, a theme that informs specific discussions on student housing.

News articles, editorials, and opinion pieces in The Daily Athenaeum chronicled student perspectives on in loco parentis policies. These writings demonstrate WVU students' critical thinking on issues that were central to their daily lives. Dress codes were among the policies that students perceived as stifling and discriminatory. In the first half of the twentieth century, ladies magazines and etiquette books instructed young women to pursue education in proper dress before heading off to university, so that they not only followed the institution's rules, but conformed to the social standards these rules were meant to enforce. Such rules originated in

\footnotetext{
${ }^{6}$ Pride and Drew, As Others See Us, 83-85.

${ }^{7}$ You and WVU student orientation booklet, folder "Publications - Student Orientation, 1966-67," Coll. 3345, W. Allen Woodford papers, West Virginia and Regional History Center, West Virginia University.

${ }^{8}$ Facts: West Virginia University student orientation booklet, July 1966, folder "Publications - Student Orientation, 1966-67," Coll. 3345, W. Allen Woodford papers, West Virginia and Regional History Center, West Virginia University.

${ }^{9}$ Dee Hoffman, "Dorms Overflow - Too Many Coeds," The Daily Athenaeum, September 12, 1967, 3; John Burch, "Zoning Cause of Housing Troubles," The Daily Athenaeum, October 14, 1965.
} 
single-sex institutions but carried over into coeducation institutions once they were opened to female students. ${ }^{10}$ At WVU in the 1960s, students such as Lorena Cook and Harry Baisden criticized dress codes at football games, connecting a lack of school spirit to the insensible dress codes required of students. A female student required to wear heels could "find herself tottering back and forth on the edge of the bleachers" amid an exciting moment of the game, while the men avoided becoming overheated in their sport coats and suits. "Are we afraid to break an antiquated tradition that is actually not hurting the school?" the writers questioned, citing more casual attire found on other campuses as more comfortable and "conductive to spirit" at games. ${ }^{11}$ These discussions suggest students not only favored comfort and choice, but felt more engaged with school spirit while doing so.

For some freshmen, the traditional WVU beanie first-years sported during Mountaineer Week seemed as dated as dress codes. While some found the beanie sentimental, others felt it set the freshmen apart within the student body. Students such as Victor Alessandra argued it was an unnecessary tradition that cost freshmen their money - and their dignity. "We are continually criticized for our lack of spirit, lack of cooperation, [and] lack of academic excellence," he lamented. "A beanie is purchased, worn for a day or two, then stuffed into a drawer...I would like to know what earthly good is actually accomplished by freshmen wearing beanies."12 Others found the beanies demeaning, as irrelevant as "Homecoming Queens" and harking back to a "by-gone era when hazing was in vogue." ${ }^{\prime 13}$ Such reactions suggest that what appears to have been a harmless tradition did affect how freshmen perceived themselves and their relation to

\footnotetext{
${ }^{10}$ Faehmel, College Women in the Nuclear Age, 43-45; Horowitz, Campus Life, 228; Deirdre Clemente, "'Prettier Than They Used to Be': Femininity, Fashion, and the Recasting of Radcliffe's Reputation, 1900-1950," The New England Quarterly 82, no. 4 (2009): 640-641.

${ }^{11}$ Lorena Cook and Harry L. Baisden, “Ties, heels? No! Let's 'Dress Down' for Games," The Daily Athenaeum, September 23, 1966, 4.

${ }^{12}$ Victor N. Alessandra, "Letter to the Editor," The Daily Athenaeum, December 2, 1960, 4.

13 “A necessary tradition?” The Daily Athenaeum, September 23, 1970.
} 
students in other classes. Those who rejected the beanie tradition sought more social equality among WVU classes.

Housing broke along the lines of gender and age. Female students felt the strict rules and cramped living spaces were a "definite deterrent" of enrollment at WVU. ${ }^{14}$ The Dean of Women, Betty Boyd, recommended "a gradual granting of freedom" to help female students adjust to campus life. In her letters to parents, Boyd assured them that the University would care for their daughters and keep lines of communication open. Parents could choose a "plan" that indicated the level of freedom their daughters could receive. Of particular concern was the frequency and distance from campus a female student could travel. Parents could choose from a variety of plans. One plan required permission letters before their daughter could travel more than eight miles from campus. Another plan required female students to earn her ability to travel home for the weekend only if she did not miss classes. One option did allow female students to travel "at any time...the decision as to whether she can afford to miss classes will be her's to make."15 Unfortunately, records on the responses to these plans are not available, which would shed light on parent decision-making. Still, because four of the five options required permission letters, these plans demonstrate the level of involvement between the University and students' parents. It recognizes that the University sought parental approval while holding students partially responsible for their actions.

In loco parentis policies restricted female students in making decisions about their housing, daily activities, and their person. Students such as Kitty Melville expressed frustration with the in loco parentis policies that felt judgmental and juvenile. In an opinion piece in The

\footnotetext{
${ }^{14}$ Holter, Student Housing: West Virginia University, 1.

${ }^{15}$ Letter to parents from Betty Boyd, WVU Dean of Women, undated, folder "Suspension and Probation Information," Coll. 2833, West Virginia University Office of Student Life Records, West Virginia and Regional History Center, West Virginia University.
} 
Daily Athenaeum, she equated these rules to "a constant game of Mother, May I?" "WVU women have a number of mothers," Melville wrote. "There's the one who gives them warnings and restrictions, the one who takes care of the dorm and tucks them in each night, and the one who watches from Moore Hall." Melville went on to ask the "mother" who she could date, what and where she could eat and drink, how she could furnish her dorm, and whether or not she could own a car, get a job, or use birth control pills. "It's a child's game," Melville wrote. "Most WVU coeds play it." ${ }^{\prime 16}$ By connecting her experiences to a "child's game," Melville demonstrates not only how female students were uniquely affected by University policies, but how these policies made her feel like a child who had not earned the trust of her parents. Her fellow student, Cheri Moran, argued that female students had been breaking the rules of this "child's game" in the past and they would continue to do so in the future. These policies, according to Moran, were not only unnecessary, but signaled the University's mistrust in female students. Rather than allowing female students to make decisions about who they visited behind closed doors, these policies, she argued, were "part of the University's archaic function of playing nursemaid to thousands of students mostly over 18 - and a great many over 21."17 These perspectives shed light on how housing policies, aimed at regulating behavior, affected individual emotions and self-image on a day-to-day basis.

Policies regulating student behavior also extended to the classroom. Some students argued they should not be required to attend class. Student and The Daily Athenaeum contributor, Joyce Breach, connected student decision-making to class attendance. "The University often reminds the student body that it is an intelligent group of adults capable of handling

\footnotetext{
${ }^{16}$ Kitty Melville, “Mother, May I?” The Daily Athenaeum, October 31, 1967, 4.

${ }^{17}$ Cheri Moran, “Abolish the Rule: Let Women in Men's Apartments," The Daily Athenaeum, September 13, 1966, 2.
} 
responsibility," Breach wrote, "and yet, at the same time, fails to give students the responsibilities they feel they have a right to assume." Breach's editorial, and the fact that 100\% of students polled on the issue supported non-compulsory attendance, reveals how students of the 1960s sought to control their lives both in and out of the classroom. ${ }^{18}$

Through challenges to compulsory attendance, students also demonstrated a power struggle with professors. Professors had varying perspectives, some arguing that individual professors should be able to lay down the rules of his or her classroom, while others felt noncompulsory attendance was appropriate for honors students and certain types of courses.

Students, however, hoped that non-compulsory attendance would put pressure on professors to “either sharpen up their lecture material or face an empty classroom.” Although students recognized the importance of attending interactive courses such as labs, language courses, and physical education, they characterized lectures as "dull, 50-minute rehashing of the course text with a professor's threat of cutting grades hanging over [students'] heads." Students' animosity towards this type of environment seemed to originate around issues of power. "Too often, the University gives professors too much power to judge and their judgment isn't always right regarding student character and maturity," Carolyn Scherr, a physical therapy student, lamented to The Daily Athenaeum, "The University expects students to be responsible adults and yet they won't give you an inch." 19 Although these perspectives circled around academic concerns, they centered on questions of student responsibility and maturity.

Those claims of responsible adulthood faced uncertainty when considering student alcohol consumption. Until 1986, West Virginia's drinking age was 18, meaning that the large

\footnotetext{
${ }^{18}$ Joyce Breach, "Why Require Attendance?” The Daily Athenaeum, October 6, 1965, 2.

${ }^{19}$ Joyce Breach, "Why Require Attendance?" The Daily Athenaeum, October 6, 1965, 2; Joyce Breach, “Attendance - Some Yes's and No's," The Daily Athenaeum, October 6, 1965, 2.
} 
majority of students were of age to buy and consume alcohol legally. Still, universities were, and still are, obligated to reflect the law with policies against underage drinking and alcohol abuse. ${ }^{20}$ At WVU in the 1960s, the question of whether the student union, the MountainLair, should sell beer rallied student interest in University policy. Though alcohol policy functioned under state law far more than, say, dress codes, students still criticized the University's parental oversight. In a letter to the editor published in The Daily Athenaeum, Jim Sims, self-identified as "the campus alcoholic," equated WVU's ban on alcohol at Mountaineer Field and in the MountainLair to antiquated dress codes. Such rules were not simply limiting student behavior, he argued, but depriving students of making decisions on their own, an essential part of adulthood. "It is about time the University permits students to grow up and also realize that they are not, can not, and should not be parents away from home," he wrote. ${ }^{21}$

Some students simply felt WVU was behind the times in alcohol policy, and that the University was missing an opportunity to benefit from selling beer on-campus at the MountainLair. Joan O’Connor noted that Cornell University had been selling beer on campus since 1937. “They have beer - why can't we?" she wondered. ${ }^{22}$ The majority of students argued the MountainLair was a more practical and reasonable place for students to drink. It was a safer atmosphere, as opposed to some of the city's cheap, dingy bars and the University would bring in much-needed profits from the drinks students would buy elsewhere anyway. ${ }^{23}$ However, students also felt that by being permitted to drink on-campus, the University would demonstrate its trust in the student body. By providing students with the "freedom of choice," the University would

${ }^{20}$ Hoekema, Campus Rules and Moral Community, 135-137.

${ }^{21}$ Jim "Duke" Sims, "Let's Grow Up," The Daily Athenaeum, October 10, 1967, 2.

22 Joan O'Connor, "Why Can't We?” The Daily Athenaeum, October 19, 1967.

${ }^{23}$ Suzanne Jett, "The Right to Decide," The Daily Athenaeum, October 13, 1967, 2; Joan O'Connor, "Why Can't We?" The Daily Athenaeum, October 19, 1967; Doherty and Summers, West Virginia University, 312-313. 
be upholding democratic ideals and allowing students to reason good choices from bad. Students like Suzanne Jett compared the University to an overprotective parent, afraid to give their children a piece of candy in fear of rotten teeth. Instead, she reasoned, the majority of students who would responsibly consume beer should not be punished for the few who "might overindulge." "The assumption in our society is that a person is responsible enough to make decisions in his best interest," Jett wrote. "Freedom of choice is the individual's privilege to make not only good decisions but also bad ones, else it wouldn't be a choice." ${ }^{24}$ Even when 2,600 students came out to vote on the issue in 1967, beer would not be sold in the MountainLair until 1971, when the Board of Regents authorized the sale of beer on public university campuses. Still, the controversy reveals growing activism around issues affecting individual students and their peers on a daily basis. ${ }^{25}$

Through dress codes, housing policies, academic attendance policies, and alcohol regulation, WVU students argued their dislike of in loco parentis. Their desire for freedom to make decisions was integral to their academic and individual lives as young adults. While some students disproved of a parental figure in the University all together, others argued the University was a misguided parent, enforcing trivial rules while real problems went unresolved. Teresa Rash, a staff member of The Daily Athenaeum, described how she felt unsafe walking through the unlit parking lot at Woodburn Hall after working late into the evening. She contrasted the fear she felt while searching for her car in the dark to WVU's enforcement mandatory class attendance, women's hours, and dorm residence until the age of 21. "The University may take the place of my parents here," Rash wrote, "but I know my parents would never allow our

\footnotetext{
${ }^{24}$ Suzanne Jett, "The Right to Decide," The Daily Athenaeum, October 13, 1967, 2.

${ }^{25}$ Joan O'Connor, "Why Can't We?" The Daily Athenaeum, October 19, 1967; Rich Gazarik, "Regents OK campus beer," The Daily Athenaeum, September 21, 1971, 1.
} 
driveway at home to be so poorly lighted and such a place of potential danger to any of their children."26

With his inauguration in 1968, WVU President James Harlow ushered in an era supportive of student democracy and freedom. With recognition that WVU was "entering maturity as a modern state university," he made efforts to move away from in loco parentis policies. ${ }^{27}$ New housing codes required only freshmen to live in University-owned dorms and lifted women's curfew hours, which “personally pleased" more students than Harlow's initiatives for minority representation and environmental awareness. A revamped Code of Conduct and housing codes restructured student-university relationships and allowed for a more relaxed student experiences. ${ }^{28}$

Into the 1970 s and beyond, students nationally grew more independent and commanding of their educations, while universities and their cities used new codes to keep students' offcampus behavior in line. Youth culture of the late twentieth century empowered teens entering college and seeking their place in the world. ${ }^{29}$ Still, in light of their newfound independence, students sought new types of protections from their universities. Rather than serving as a parent, the university could be a student's advocate in instances of injustice, crime, or injury. ${ }^{30}$

Into the late $1980 \mathrm{~s}$, students still referred to in loco parentis when dealing with administration. It remained a powerful construct of student-university relationships. When the

\footnotetext{
${ }^{26}$ Teresa Rash, "Double Standard,” The Daily Athenaeum, October 10, 1967, 2.

27 “President's Harlow's Inaugural Address," West Virginia University Alumni News, Fall 1968, Vol. 34, No. 2, 4 .

${ }^{28}$ Doherty and Summers, West Virginia University, 309-311; "Code of Conduct draws acclaim, criticism," The Summer Athenaeum, August 13, 1970, 1; "Changes in code approved," The Daily Athenaeum, February 17, 1972. 329.

${ }^{29}$ Gumprecht, The American College Town, 37-39; Thelin, A History of American Higher Education, 326-

${ }^{30}$ Annette Gibbs and James J. Szablewicz, “Colleges' New Liabilities: An Emerging New In Loco Parentis,” Journal of College Student Development, Vol 29 (March 1988): 100, 104.
} 
new Mountaineer Field opened on the Evansdale campus in 1980, issues of student behavior during games only relocated. Football games were a place where students and administration tested one another's patience. The method of solving this issue was constantly in flux. Overall, students disliked methods reminiscent of in loco parentis control. The use of "omniscient" cameras and threats of suspension registered as "scare tactics" to some students. ${ }^{31}$ Similar criticisms appeared in conversations around on-campus housing. In 1988, due to overcrowding in the dorms, freshmen were permitted to choose their own housing for the first time. Some students argued that Residence Life "coerced" students into living in the dorms anyway. An editorial writer for The Daily Athenaeum rationalized these actions as a leftover of in loco parentis, in which Residence Life still sought to control students by eliminating "freedom of choice." "When the rest of the University is telling the freshmen, 'you're your own boss now,' the department of Residence Life is adding, 'except when your day is finished and you come home. Then, it's like you're living with your parents again." ${ }^{32}$ Again, central to this issue was how decision-making could foster students' personal maturity. In a time without in loco parentis, students and universities had to redraw the boundaries of their relationships.

\section{Student Freedoms and Off-Campus Housing}

As a new school year began in August 1968, the Mountaineer Freedom Party, a left-wing activist group at WVU, published a handout that sought to "raise fundamental questions about the way the University is being run." In large, capital letters handwritten across the top of the page, the handout read: "DADMINISTRATION," comparing the University to an overbearing

\footnotetext{
31 "Lay down the law," The Daily Athenaeum, September 12, 1986, 4.

32 "Coercion: Residence Life twists arms," The Daily Athenaeum, August 23, 1988, 4a.
} 
parent. "You have come to the University thinking you are going to become part of an adult community of students and scholars," the handout read. "Why has the University adopted a policy of in loco parentis? Is this the proper relationship with a university and its students?"33

In asking questions of personal freedom and responsibility, the Mountaineer Freedom Party challenged students to reimagine the student-university relationship. Other activist groups, as well as writings in The Daily Athenaeum, began to highlight a growing issue in Morgantown: the quality and accessibility of off-campus housing. For students discussing about these issues, off-campus housing provided more than a roof over one's head. To live off-campus symbolized independence, responsibility, and personal ownership. Some argued that by breaking down in loco parentis policies at WVU, students could not only be freed from the parental oversight of the University, but also fulfill their individual potentials as adults. Examining conversations of off-campus housing can shed light on student conceptions of their identities and their relationships with the University.

Numerous factors affected students' decisions to live off-campus. A student first had to be eligible to live off-campus through University policy. In 1972, the University approved changes to housing policy, requiring only freshmen students to live on campus and eliminating women's curfew hours. These changes allowed upperclassmen more choice in where they could live. ${ }^{34}$ Those who were eligible exercised these privileges for practical reasons. Cost, proximity to campus, and fewer rules and regulations were significant deciding factors. ${ }^{35}$ Yet living in an

${ }^{33}$ Mountaineer Freedom Party "Dadministration" handout, 29 August 1968, folder "Students for a Democratic Society (SDS)," Coll. 2833, West Virginia University Office of Student Life Records, West Virginia and Regional History Center, West Virginia University.

34 "Changes in code approved," The Daily Athenaeum, February 17, 1972; Kathy Della Torre, "Housing rules to change," The Daily Athenaeum, February 17, 1972.

${ }_{35}$ Bob Verbosky, "Prices Prompt Males to Occupy Apartments," The Daily Athenaeum, September 8 , 1966, 1; Susan Malone, "Choosing the proper living quarters," The Daily Athenaeum, August 21, 1986, 9b; SOURCES 
apartment or rental house came with freedoms that shaped students' newfound independence. In off-campus housing, students had more choice in their roommates, could organize and decorate their spaces to their liking, and could cook and have access to a kitchen. One student simply stated, "I can do what I please, when I please, and how I please in my apartment."36

Some students felt that living off campus prepared them for the "proverbial real world." They faced the decision of choosing where and with whom to live, a decision that, while "complex and consequential," allowed students to have the control over their lives they desired. ${ }^{37}$ Additionally, students faced day-to-day decision making in off-campus housing, as they independently chose how to care for a living space, manage rent and utilities, and live alongside roommates. For some students, this "first bite of freedom" made them realize the magnitude of living independently. ${ }^{38}$ For example, acquiring furnishings for an apartment proved to be a challenge. Because a student's budget could not afford quality pieces, they first shopped secondhand or in the "basements of friends and relatives." Those who had saved enough money were recommended to invest in pieces that would "prove useful in post-college years." ${ }^{39}$ Some struggled with difficult landlords, who would not respond to repair requests or make sudden policy changes. ${ }^{40}$ Still, students felt that the freedoms they experienced in off-campus housing were "worthy of the added responsibilities and inconveniences."41

Shifts in on-campus housing suggest WVU's awareness of changing student interests. In 1967, for example, WVU opened Pierpont house, a \$2 million, nine-story apartment complex on

\footnotetext{
${ }^{36}$ Bob Verbosky, "Prices Prompt Males to Occupy Apartments," The Daily Athenaeum, September 8, $1966,1$.

${ }^{37}$ Susan Malone, "Choosing the proper living quarters," The Daily Athenaeum, August 21, 1986, 9b

${ }^{38}$ Bob Bestwick, "The hidden perils of apartment living," The Daily Athenaeum, October 1, 1985, 4.

${ }^{39}$ Susan Malone, "A student should know basics of furnishing a first apartment," The Daily Athenaeum, August 21, 1986, 5b.

${ }^{40}$ Charles Gardner, "'U' Officials Should Crack Down,” The Daily Athenaeum, September 22, 1966; "Union formulates list: Tenants air grievances," The Daily Athenaeum, January 13, 1972.

${ }^{41}$ Susan Malone, "Choosing the proper living quarters," The Daily Athenaeum, August 21, 1986, 9b
} 
the Evansdale campus. Seen as an experiment in student housing, Pierpont offered housing to both male and female students and limited their supervision, while still enforcing in loco parentis policies such as curfews. The University took this approach to see how students "handle their freedom with responsibility."42

The private sector saw a need and an opportunity to build dormitories of their own, yet within a few years, up to four of these new dormitories would close, despite the continuing demand for student housing. This dichotomy - of new dormitories, both private and universityowned, attempting and failing to solve a local housing problem - reflected a shift in student culture, both locally and nationally. Students associated dormitory living with traditional in loco parentis control. $^{43}$

Greek life also disenchanted students in the mid-1960s. Student interest in off-campus housing originated in the rise of fraternal organizations in the nineteenth century, which also benefited universities with housing shortages. These organizations remained popular until they lulled, like most of traditional American life, during World War II. In the years following, studious veterans on the GI Bill expressed little interest in Greek life. By the mid-1950s, however, Greek life revived and thrived in an era of conservativism, anticommunism, and social segregation. Although fraternities and sororities were founded on democratic principles of leadership, community, and service, progressive students perceived Greek life as antidemocratic in nature. Coupled with accusations of hazing, sexual assault, racism, homophobia, and elitism, Greek life faltered again in the 1960s. ${ }^{44}$ 1967.

${ }^{42}$ Robert DeFrancis, “Pierpont - Will Students Make it Work?” The Daily Athenaeum, September 15,

43 "Statements on Housing at WVU Are Released," The Charleston Gazette, February 15, 1979, 1A, 12A.

${ }^{44}$ Horowitz, Campus Life, 42-45, 111-112; Nicholas L. Syrett, In the Company He Keeps: A History of White College Fraternities (Chapel Hill: The University of North Carolina Press, 2009) 234-284; Doherty and Summers, West Virginia University, 312; “To Join or Not to Join,” The Daily Athenaeum, September 27, 1960, 4; 
At WVU, even in a time when most students were independent, Greeks remained prominent members of the WVU community. Fraternity brothers served as student body presidents every year since the end of World War II, a trend that would not break until the mid1970s. Still, with burgeoning enrollment, more WVU students preferred independence over Greek status. Some questioned the practicality of joining Greek life, citing cost and time commitment. ${ }^{45}$ Students such as George Doughty, agreed with these practical rationalities for avoiding Greek life, but added that his decision was for the betterment of his personal growth. "I have found what it is to try something on my own and to succeed or fail, not as a member of ' $\mathrm{X}$ ' organization, but as an individual." 46

As students forwent the romanticism of Greek life and sought amendments to in loco parentis policy, off-campus housing became a pertinent topic of conversation. The Daily Athenaeum covered off-campus housing thoroughly and critically in their news coverage, editorials, and letters to the editor. As the most popular source of campus information, The Daily Athenaeum writings show the variety of conversation around off-campus housing. ${ }^{47}$

News articles covered student "housing woes," such as poor living conditions and housing shortages. ${ }^{48}$ Editorials recommended strategies on how students should deal with offcampus housing issues. They emphasized student-tenant rights and steps for avoiding or managing cases of abuse. One editorial recommended students who felt they were swindled from

\footnotetext{
Roy Costa, "Black students present demands to University," The Daily Athenaeum, August 7, 1969; Sandi Saville, “Greek Noise Under Fire," The Daily Athenaeum, September 21, 1967, 1.

${ }^{45}$ Doherty and Summers, West Virginia University, 312; "To Join or Not to Join," The Daily Athenaeum, September 27, 1960, 4.

${ }^{46}$ Student Administration booklet, "Why I Chose to Be an Independent" article by George Doughty, 1967, folder "Publications - Student Orientation, 1966-67," Coll. 3345, W. Allen Woodford papers, West Virginia and Regional History Center, West Virginia University.

${ }^{47}$ Pride and Drew, As Others See Us, 81.

${ }^{48}$ Charley Cumpston, "Housing Woes for Sale; Rickety Rooms Available," The Daily Athenaeum, September 16, 1965, 1; more sources
} 
high rent payments could submit complains to the IRS, which could encourage landlords to comply with federal law or open an investigation. ${ }^{49}$ Another instructed student tenants to ensure their landlords had smoke detectors properly installed in sleeping quarters, and to contact the local fire department and building inspector if violations were observed. ${ }^{50}$ These publications suggest how students, both writing and reading The Daily Athenaeum, realized the importance of off-campus housing issues.

Students debated whether it was the University's responsibility to ensure quality offcampus housing. The Daily Athenaeum editor, Sherry Moran, argued that because the University had no legal authority to declare a house unsafe for student occupancy, off-campus housing was ultimately the city's problem, not theirs. The University attempted to mediate this issue by allowing the University Housing Office to set standards and compile lists of housings deemed safe enough for students to pursue. These actions, according to Moran, were a sign the University was trying to help. The real culprit was the city's lax building codes, which excluded minimum occupancy provisions under health and safety standards. In turn, she called for "a strong student voice" to advocate for code revisions. "The passage of such codes would be a service not only to the University but to the entire community." ${ }^{, 51}$

Among the students working to rid WVU of in loco parentis policies were liberalprogressives in the late 1960s and early 1970s. Their activism, while unique in method and political approach for a WVU group, demonstrates the significance of housing as part of a larger activist platform, and student freedoms as central to reimagining student-university relationships. In this time, student movements across American university campuses sprung from grassroots

\footnotetext{
49 "Law-breaking landlords; how to fix their wagons," The Daily Athenaeum, September 14, 1971, 2.

${ }^{50}$ Kathe Knotts, "Smoke detectors: safety-valve," The Daily Athenaeum, January 10, 1979, 10.

${ }^{51}$ Sherry Moran, “Death-Trap' Apartments: Housing City’s Problem," The Daily Athenaeum, September 23, 1965, 2.
} 
organizing rather than a national group like the Students for a Democratic Society (SDS), which rose and fell within ten years of its establishment. Students, shaped by ongoing violence in Vietnam and highly publicized demonstrations, tackled social inequalities on college campuses. ${ }^{52}$ Housing inequality was among these issues.

WVU students advocated for important causes in the 1960s. While campuses ranging from Brooklyn to Berkeley pulsed with activism, WVU students, as often the "first generation out of the hills and hollows," tended to focus more on earning degrees than sparking revolutions. ${ }^{53}$ West Virginia also had the highest per capita death rate for soldiers in Vietnam, giving little base for antiwar efforts. ${ }^{54}$ Three in four WVU students also supported non-violent protest activity "that [did] not interfere with the rights of others on campus." ${ }^{, 55}$ Student political organizations at WVU incorporated housing issues as part of their platforms. WVU had two political organizations, the Student Party and the All-Campus Party, until 1969, when the Mountaineer Freedom Party was established. Groups such as the Mountaineer Freedom Party, the SDS, and Student Activist League advocated for a student's ownership of their self and their education. This sprung from a philosophy that perceived education as a right rather than a privilege. A branch of the SDS was established in either 1966 or 1967 and folded by 1969. Although its presence at WVU was relatively short, its platform embodied national trends related

\footnotetext{
${ }^{52}$ Winifred Breines, "Whose New Left?" The Journal of American History, vol. 75, no. 2. (Sept. 1988): 529-531; Breines, Community and Organization in the New Left, 12

${ }^{53}$ Lewis, Aspiring to Greatness, 285. One antiwar protest occurred at WVU from May 5-7, 1970, in response to the Kent State shootings and invasion of Cambodia. For more information on student activism and demonstrations at WVU in the 1960s-1970s, please reference Lewis, Aspiring to Greatness, 284-303, and Doherty and Summers, West Virginia University, 307-324, and Jeffrey A. Drobney's article, "Generation in Revolt: Student Dissent and Political Repression at West Virginia University."

${ }^{54}$ Jeffrey A. Drobney, "Generation in Revolt: Student Dissent and Political Repression at West Virginia University." West Virginia History. Vol. 54 (1995), http://www.wvculture.org/history/journal wvh/wvh54-6.html.

${ }^{55}$ Pride and Drew, As Others See Us, 87.
} 
to higher education. In particular, it emphasized student ownership of the University. " ${ }^{56}$ "This is YOUR university, not theirs," one SDS document charged. ${ }^{57}$

While student activists envisioned a more democratic form of higher education, they also understood the broader influence of universities. Housing, therefore, was often an important component of their missions. The Mountaineer Freedom Party was the most vocal group at WVU. Members addressed a number of issues on student rights and freedoms, one of which was housing. Their holistic approach to radical change advocated for a change in the system of running higher education, rather than tinkering with the legalities. ${ }^{58}$ They addressed housing inequality as a symptom of larger issues, including the University's "indifference" toward poor dormitory services, lackluster communication and information systems, the city's lack of a tenants' union representing students as Morgantown community members, and discrimination by sex and race. ${ }^{59}$ Of the 373 members of the Mountaineer Freedom Party, around 44 lived in Sunnyside, including two organizational leaders, Brad Pyles and Rick Franzblau, suggesting that Sunnyside housing conditions could have influenced their platform. ${ }^{60}$

The Student Activist League, a formally unrecognized political organization at WVU, was born from history student Scott Bills's activism after the Mountaineer Freedom Party folded. In a dramatic moment, members of the Student Activist League burst into President Harlow's

\footnotetext{
${ }^{56}$ Bob S. Berlan, "Third campus party to begin operations," The Daily Athenaeum, January 22, 1969, 1; "Parties split on issues of ROTC and U housing," The Daily Athenaeum, March 3, 1970, 1; Bob Arnold, "WVU's version of activism is inactive," The Athenaeum Insight, October 24, 1969.

${ }^{57}$ SDS orientation document, 20 July 1970, folder "Students for a Democratic Society (SDS)," Coll. 2833, West Virginia University Office of Student Life Records, West Virginia and Regional History Center, West Virginia University.

${ }_{58}$ Bob S. Berlan, "Third campus party to begin operations," The Daily Athenaeum, January 22, 1969, 1; "Young Republicans discuss University codes of conduct," The Daily Athenaeum, September 18, $1970,1$.

59 Mountaineer Freedom Party "1970 Platform" document, 1970, folder "Student Elections; student political parties," Box 11389C, Coll. 2828, Scott Bills papers, West Virginia and Regional History Center, West Virginia University.

${ }^{60}$ Mountaineer Freedom Party member directory, folder "Student Elections; student political parties," Box 11389C, Coll. 2828, Scott Bills papers, West Virginia and Regional History Center, West Virginia University.
} 
office with "13 Demands," signed by more than 200 students. These demands covered a variety of issues the Student Activist League found unjust at the University. One demand addressed housing standards and activities related to housing. They argued that off-campus housing should meet certain minimal standards before they may be listed in the category of "WVU approved housing," with vented heating systems, safe electrical wiring and appliances, higher load levels on electricity, reasonable rent, and assurance that tenants would not be discriminated against. To ensure this occurred, they requested reports from the state fire marshal and a student committee overseeing student housing. Additionally, they asked for more relaxed visitation hours and more construction of student apartments over dormitories. ${ }^{61}$ The Student Activist League argued that by addressing the power struggle with the University, students could receive a better education. "This is one of the reasons for the thirteen demands: to make students more aware of how they are allowing themselves to be treated by the administration, and to show them an alternative $-\mathrm{a}$ course of action that would preserve the learning experience." 62

Students also became involved outside the University to advocate for better housing. The Morgantown Tenants Union, established in 1972, supported both students and citizens of Morgantown in "raising the level of rental housing to a decent standard" in Morgantown. Students could present the Union with complaints and then serve as students' representatives,

${ }^{61}$ Letter to Student Administration, New and Information, Barbara Wickline. Tentative Proposal for WVU Housing Authority as it Relates to SAL Demand Number 11, folder "Student Activist League and 13 Demands 1969-1970, and no date," Box 11389B, Coll. 2828, Scott Bills papers, West Virginia and Regional History Center, West Virginia University; Letter to Student Administration, News and Information. Student Activist League Thirteen Demands, folder "Student Activist League and 13 Demands - 1969-1970, and no date," Box 11389B, Coll. 2828, Scott Bills papers, West Virginia and Regional History Center, West Virginia University; Jeb Kresge, "SAL rephrases 6 demands," The Daily Athenaeum, January 30, 1970, 1.

62 "Men or Mice, Squeak Up!" document, folder "Student Activist League and 13 Demands - 1969-1970, and no date," Box 11389B, Coll. 2828, Scott Bills papers, West Virginia and Regional History Center, West Virginia University 
which would "bear more weight" in resolving housing and landlord issues. "When tenants refuse to accept slum conditions, the landlords will have to change or go under," one article argued. ${ }^{63}$

Members complained of "leaky faucets, unvented heaters, rats, roaches, faulty electrical wiring, inadequate fire exits, bad plumbing, hazardous stairways, and high rents." Student members of the Morgantown Tenants Union argued that the opportunity to be exploited was much more probable because of the nature of a college town. "The average landlord...will take full advantage of the big demand for off-campus housing," one student wrote in The Daily Athenaeum. "The landlord can charge nearly any price he wants. He needn't be in a great hurry to do repairs either. In fact, he can pretty well call the shots as he likes."64 Such a relationship between student tenants and landlords was common across college towns in the United States. ${ }^{65}$ In 1972, the Morgantown Tenants Union compiled a "blacklist" of landlords after negotiation attempts from the previous year fell through. "One lengthy grievance” involved a Sunnyside residence which imposed strict rules on tenant behavior, such as "only residents of the house can sit on the porch; no alcoholic beverages are allowed on the porch; no girls are allowed in the residence; overnight guests are not allowed; and typing is restricted past 1 pm." ${ }^{\circ 6}$ These grievances show how students not only had to grapple with WVU's perceptions of their freedoms, but also their landlords.

These discussions complicate student-university and town-gown relationships in terms of housing. While students demanded the freedom to live how and where they pleased, they also recognized the power of the University and the city of Morgantown. With this power, they reasoned, should come the responsibility to ensure students had a safe place to live, whether on-

\footnotetext{
63 "Student Speaking: Tenants union proposes blacklisting," The Daily Athenaeum, January 11, 1972.

${ }^{64}$ Ibid.

${ }^{65}$ Gumprecht, The American College Town, 89-95.

66 “Union formulates list: Tenants air grievances," The Daily Athenaeum, January 13, 1972.
} 
campus or off-campus. Students also advocated for more power of their own, organizing on a grassroots level to initiate change surrounding local housing issues.

\section{The 1979 Housing Referendum}

"Home sweet away-from-home? Only if you are lucky." "67

WVU students appreciated having choice in their housing, but not necessarily the options available. Into the 1960s, as WVU's enrollment increased and a housing shortage ensued, the quality of existing off-campus housing became a more pressing concern. Characterized by "dilapidation and scarcity," the physical condition of rental housing posed health and safety concerns for tenants, while relations with landlords and the city complicated the matter. ${ }^{68}$ Students, frustrated by these issues, rallied enough votes to have a housing referendum passed in 1979 to establish minimum housing standards in Morgantown. This victory did not completely resolve off-campus housing issues, which persist to this day. However, the 1979 housing code is an example of students, in an era of waning in loco parentis, taking it upon themselves to solve problems the University and the city struggled to address. The code, which passed by a mere 67 votes, also exposes Morgantown's town-gown tensions. ${ }^{69}$ Students, as a temporary, transient community, faced praise and criticism for participating in local politics, but nonetheless added their voices to a community-wide problem.

In 1960, the University, in partnership with Morgantown's fire and health departments, published the first extensive survey of off-campus housing. Issues related to the health and safety

\footnotetext{
${ }^{67}$ Charley Cumpston, "Housing Woes for Sale; Rickety Rooms Available," The Daily Athenaeum, September 16, 1965, 1 .

${ }^{68}$ James A. Haught, "Nightmare of an Apartment Fire Real Horror for WVU Students," Charleston Gazette, February 11, 1979, 4A; Pride and Drew, As Others See Us, 100.

${ }^{69}$ According to Pride and Drew's study, 64\% of students were dissatisfied with town and gown relations, one student writing calling for more student influence on decision-making in the Morgantown community.
} 
of Greek housing prompted an investigation of housing "over which the University or city exercise[d] no supervision or control. ${ }^{, 70}$ Their findings confirmed many students' firsthand experiences. Although students were free to decide where and how they lived, the cheapest and most readily available off-campus housing in Morgantown consisted of older homes refitted into apartments that often did not adhere to codes. $75 \%$ of this housing was located less than half a mile from the center of campus, which encompassed Sunnyside, the most convenient choice in a city rife with pervasive transportation and parking issues. The housing problem turned out to be much larger in scope than originally believed, stalling the University's plans to take action. ${ }^{71}$

By 1970, WVU's student body more than doubled from ten years earlier. WVU responded with new dormitories on the Downtown and Evansdale campuses. ${ }^{72}$ Female students were no longer required to live in campus housing. ${ }^{73}$ Greek housing fell more out of fashion in favor of apartments, which offered students "fewer restrictions and more individualism." Construction of new private housing continued, yet could not keep up with rising populations. Amid this era of building renovations, new construction, and a substantial focus on athletic spending, students wondered what their role would be in ensuring quality off-campus housing. ${ }^{74}$ Although WVU was a relatively quiet campus, a characteristic that politically-minded student criticized, housing became an issue that students could rally behind.

Local "housing headaches" impacted both WVU and the city of Morgantown. Issues involved the buildings' physical structures and facilities, including poor heating, cooling, and

\footnotetext{
${ }^{70}$ Holter, Student Housing: West Virginia University, 1.

${ }^{71}$ Ibid., 10, 20, 44-46; Jerry Ash, "Housing Action Delayed," The Daily Athenaeum, September 30, 1960, 1.

${ }^{72}$ Lewis, Aspiring to Greatness, 188; 280. New dormitories built in the 1960s included Knapp Hall, Summit Hall, Glenlock Hall, Centennial Hall, and Pierpont Hall. Glenlock and Centennial were unfilled and converted for other purposes.

${ }^{73}$ Lewis, Aspiring to Greatness, 188.

74 "Statements on Housing at WVU Are Released," The Charleston Gazette, February 15, 1979, 1A, 12A; Doherty and Summers, West Virginia University, 321, 333-334.
} 
ventilation systems, broken windows and appliances, inadequate closet space, pests, and a general lack of upkeep on the buildings and grounds. ${ }^{75}$ As the University expanded, Morgantown had to adjust not only to more students, but to these students coming and going throughout the year. The influx of students every August put pressure on the city both physically and socially; the city's roads, parking, and sewers led to issues such as traffic, overcrowding, and pollution. ${ }^{76}$ Overwhelmingly, students at WVU described housing in Morgantown as either decent or in poor quality. ${ }^{77}$ Student tenants used words like "disgrace," "inadequate," "over-priced," and "a ripoff" to characterize their living conditions..$^{78}$ Additionally, some student tenants felt exploited by their landlords, whose practices varied from strict control of tenant activities to absence. ${ }^{79}$

The issue then became a matter of life and death. In the late 1970 s, when $78 \%$ of students lived off-campus, a series of houses went up in flames, claiming the lives of several students and causing serious injury to others. Instances like the fire at 14 Jones Street in Sunnyside explains why these old, converted houses earned nicknames like "deathtraps" and "firetraps." This house, lacking adequate fire safety features and escape routes, trapped a veterinary student on the top floor. Smoke inhalation sent him into a six-day coma. ${ }^{80}$ Student rentals like 14 Jones Street were high occupancy to help reduce cost and fit as many tenants as possible. Yet in exchange, these

\footnotetext{
${ }^{75}$ Pride and Drew, As Others See Us, 100; Charley Cumpston, "Housing Woes for Sale; Rickety Rooms Available," The Daily Athenaeum, September 16, 1965, 1; Charles Gardner, "Off-Campus Housing: Officials Should Crack Down," The Daily Athenaeum, September 22, 1966; Chris Knap, "Student housing: Rents often exceed property value," The Daily Athenaeum, October, 12, 1977, 1; Chris Knap, "Student Housing: disinterest, fear block path to solution," The Daily Athenaeum, October 13, 1977, 1; James A. Haught, "Nightmare of an Apartment Fire Real Horror for WVU Students," Charleston Gazette, February 11, 1979, 1A, 4A; add more sources

${ }^{76}$ Pride and Drew, As Others See Us, 44-46, 100; Charley Cumpston, "Housing Woes for Sale; Rickety Rooms Available," The Daily Athenaeum, September 16, 1965, 1; Sue Scancella, "Mayor lauds students' role in community," The Daily Athenaeum, September 4, 1980, 1.

${ }^{77}$ Luke Briggs, West Virginia University Student Attitudes Toward Morgantown: A Survey of West Virginia University Sophomores and Seniors (Morgantown, WV: West Virginia University, 1974), 31-32.

${ }_{78}^{78}$ Pride and Drew, As Others See Us, 44-46, 100

${ }^{79}$ Charley Cumpston, "Housing Woes for Sale; Rickety Rooms Available," The Daily Athenaeum, September 16, 1965, 1.

${ }^{80}$ Brooke McClimans, "One more time..." The Daily Athenaeum, June 7, 1979, 2; James A. Haught, "Nightmare of an Apartment Fire Real Horror for WVU Students," Charleston Gazette, February 11, 1979, 1A, 4A.
} 
houses were far less safe than those with an appropriate number of tenants. Fire safety, therefore, was among the most significant problems facing off-campus housing. ${ }^{81}$

A series of newspaper investigations in the late 1970s publicized the issue across West Virginia. The Daily Athenaeum reporters described living conditions of their fellow students: "The roof leaks...the upstairs toilet won't flush, and the carpet is held in place with tacks which frequently work their way out of the rug and up into the students' feet." ${ }^{, 82}$ After a change in University administration in 1977, President Gene Arthur Budig spoke in his first community address about the "critical need" for higher quality student housing. In February 1979, the Charleston Gazette published an expose on the state of WVU's student housing, an example of concern stretching beyond the city of Morgantown. The series, which ran from February 11 to 14, covered topics including fire safety, the general housing industry, the role of WVU educators in the housing business, and student activism. The University promptly responded, acknowledging that there was "definitely a housing problem in the Morgantown area and there has been one for some time." WVU's Board of Regents sent a report to the state legislature that revealed 20\% of Monongalia County housing was considered substandard. In the wake of "rapid growth...in the past fifteen years," the city struggled to meet its residents' needs. ${ }^{83}$

Considering the issues and their publicity, the Morgantown Planning Commission, fearing neighborhoods could become "blighted" by overcrowding and substandard housing, felt a comprehensive housing code was necessary. ${ }^{84}$ In September 1978, the Morgantown City Council instructed the Housing Enforcement Agency, with the help of tenant and landlord

\footnotetext{
${ }^{81}$ Holter, Student Housing, 20.

${ }^{82}$ Chris Knap, "Student housing: Rents often exceed property value," The Daily Athenaeum, October, 12 ,

83 "Statements on Housing at WVU Are Released," The Charleston Gazette, February 15, 1979, 1A.

${ }^{84}$ H. Peter Marshall, "Critical need for code seen," The Dominion Post, November 2, 1979, $12 \mathrm{a}$.
} $1977,1$. 
representatives, to research and draft a code. ${ }^{85}$ The University had a housing inspection system from the 1960s, but it was abandoned "because it was unworkable and no one wanted it," while the city had no formal system at all. ${ }^{86}$ On January 30, 1979, the Morgantown City Council submitted a proposed housing code to help ensure Morgantown rental properties met health and safety standards. ${ }^{87}$ The housing code would establish minimum standards for health and safety and required mandatory inspections every three years. Rentals were required to have hot and cold running water, adequate bathrooms, and be sanitary and free of pests. Apartments without a safe exit in a fire could not be rented. The code defined terms such as "tenant" and "dwelling." 88 President Budig agreed. "A housing code would serve to reduce much anxiety, while enhancing the state-wide image of Morgantown," he said. ${ }^{89}$

By summer, a group of landlords and local citizens called the United Taxpayers of Morgantown won a repeal of the housing code, which would then go before City Council. They argued that the code would burden "the people who render a service" in the Morgantown community. ${ }^{90}$ The Morgantown City Council chose to organize a referendum rather than repeal the proposed code. ${ }^{91}$ In light of these threats, WVU students became an integral part in getting the housing code passed. The "security" students felt after departing Morgantown for the

${ }^{85}$ James Kelly, "Local housing code facing final council vote," The Daily Athenaeum, April 13, 1979, 1.

${ }^{86}$ Chris Knap, "Student Housing: disinterest, fear block path to solution," The Daily Athenaeum, October 13, 1977, 1; Chris Knap, "Student housing: Rents often exceed property value," The Daily Athenaeum, October, 12, 1977, 1; Linda Kubas, “Off-campus housing - teamwork needed?” The Summer Athenaeum, July 9, 1970, 1.

87 James Kelly, "Local housing code facing final council vote," The Daily Athenaeum, April ?, 1979, 1-2.

${ }^{88}$ John Appezzato, "Students urged to register for pending housing referendum," The Daily Athenaeum, September 5, 1979, 1; John Appezzato, "Task Force helps students with registration," The Daily Athenaeum, September 6, 1979, 2; James Kelly, "Local housing code facing final council vote," The Daily Athenaeum, April 13, $1979,1$.

${ }^{89}$ Tony Locy, "Budig supports Housing Code in State of University address," The Daily Athenaeum, October 10, 1979, 1.

${ }^{90}$ Delores J. Moore, "Vote 'No,"” The Daily Athenaeum, October 31, 1979, 10; Marcella Williamson, "Housing code impossible to enforce, opponents say," The Dominion Post, November 1, 1979, 1b-2b.

${ }_{91}$ Brook McClimans, "One more time..." The Daily Athenaeum, June 7, 1979, 2; Danny Goodwin, "Housing code: Morgantown voters to decide controversy," The Daily Athenaeum, August 29, 1979, 1; Rick Ridgway, "Code schmode, apathy in vogue," The Daily Athenaeum, September 6, 1979, 14 
summer turned again to uncertainty as the housing code's fate rested in a vote. ${ }^{92}$ Over the next few months, WVU student efforts to pass the housing code reflected a shift in student activism in the 1970s. Unlike the Mountaineer Freedom Party and Student Activist League, which advocated for more radical action, WVU students of the late 1970s used voting as a method of taking control of local issues. Nationally, university students "had not forgotten the 1960s' lessons about the power of collective strength to influence the character of the campus," developing special interest groups and riding the momentum of the previous decade's activism. At WVU, students challenged the University in its operations, demanding new class schedules, revamped curriculum, better quality food, and safer dormitories. Not all activist movements flourished equally; student activists working in marginalized niches, such as women's rights, gay rights, and environmentalism, continued to struggle for support at WVU ${ }^{93}$ Housing, however, united students more broadly. This issue rallied students in ways that the politically-minded Mountaineers envisioned. ${ }^{94}$

Beginning in August 1979, the Student Administration, under the leadership of President Craig Underwood and Vice President Gayle Armstrong, organized voter registration, task forces, and outreach programs to educate the student body on the housing code. They sent out representatives from Greek organizations, dorms, and other campus groups to get the word out. In particular, the Task Force targeted current freshmen because, if the code passed, they would be the first students seeking off-campus housing to be affected by it. ${ }^{95}$ Most significantly, the Student Administration emphasized the importance of voting. To do this, they helped students

\footnotetext{
${ }^{92}$ Craig Underwood and Gayle Armstrong, "Your vote," The Daily Athenaeum, August 30, 1979, 12.

${ }^{93}$ Doherty and Summers, West Virginia University, 321-322.

${ }^{94}$ Stephen Paesani, "Student Control," The Daily Athenaeum, October 14, 1977, 12.

${ }^{95}$ Danny Goodwin, "Housing Code: Morgantown voters to decide controversy," The Daily Athenaeum, August 29, 1979, 1, 3; John Appezzato, "Task Force helps students with registration," The Daily Athenaeum,
} September 6, 1979, 1 . 
register to vote in Morgantown. "This election will be the most important ever to face the student body of WVU," the Student Administration declared in a letter to the editor. "If we can pass the Housing Code on Tuesday, November 6, those of us living in Morgantown apartments will be able to go to sleep with the comfort of knowing that if we awake to find our house on fire, we will be able to get out alive. Others have not been so lucky."96

Throughout 1979, The Daily Athenaeum covered housing issues in news articles, editorials, and letters to the editor. These writings demonstrate the diversity of student perspectives and experiences in Morgantown. Overall, they show how students saw themselves within the broader college town community. Some students appealed to reason, arguing that the housing code was necessary from legal and logical perspectives. As the "University City," some argued, Morgantown was obligated to uphold "the duties of a host" and provide students with adequate housing. There would not be need for such a rigorous housing code if landlords made their housing "reasonably safe and comfortable." ${ }^{97}$ Noticing the deepening divisions between themselves and a passionate enclave of landlords and local citizens, some students wondered why health and safety had become a partisan issue. Brooke McClimans, appealed to basic rights and emotion. "All students want is a safe place to stay while living in Morgantown. Wouldn't you want the same?"98

Some articles used the housing code as an opportunity for students to assert themselves as legitimate members of the community. They argued that as a state university, WVU "belongs to all the people of the state," and therefore the student body deserved to have status in the local community. ${ }^{99}$ Although Morgantown housing was a widespread problem, not everyone in the

\footnotetext{
${ }^{96}$ Craig Underwood and Gayle Armstrong, "Your vote," The Daily Athenaeum, August 30, $1979,12$.

97 "University City has the duties of a host," The Daily Athenaeum, June 14, 1979.

${ }^{98}$ Brooke McClimans, "One more time..." The Daily Athenaeum, June 7, 1979, 2.

99 "University City has the duties of a host," The Daily Athenaeum, June 14, 1979.
} 
community supported the housing code. It was first met with suspicion from landlords and student tenants alike. They expressed concerns about privacy and tax burdens, while news articles reported that "rumors and incorrect information [were] abundant."100 Opponents frequently cited cost as a reason to vote against the code; 13,000 inspections could cost the city $\$ 100,000$ a year. City Councilmen themselves wondered whether "the value of the inspections would be that high." "101 In turn, advocates asked, "Isn't it worth the money?" and noted WVU's expansive spending on a new football stadium as hypocritical. ${ }^{102}$

Among students, perspectives differed in the code's strengths and weaknesses. Some students felt that City Council was "in such a hurry" to get something passed, that they overlooked important details. One missing piece was a scale that weighed the severity of code violations and a system of demerits. Although the demerit system was removed because it gave "too much discretion to those who would enforce the code," student responses show how they measured housing violations that affected them daily. ${ }^{103}$ Students like James Kelly saw this as a significant safety concern. "Is a missing window screen as dangerous as an unvented gas space heater?" he asked. "A weak scale could turn the code into little more than a friendly visit every three years from a city inspector. A strong scale could save lives.” Still, Kelly acknowledged that their standards could not be set too high. "If every apartment in Morgantown with a cracked window pane or peeling paint was closed down, there wouldn't be enough housing left in town

\footnotetext{
100 James Kelly, "Local housing code facing final council vote," The Daily Athenaeum, April ?, 1979, 1-2; Brooke McClimans, “One more time...” The Daily Athenaeum, June 7, 1979, 2.

${ }^{101}$ Jeff Hertrick, "New setback for Morgantown housing code," The Summer Athenaeum, May 31, $1979,1$.

${ }^{102}$ Brooke McClimans, "One more time..." The Daily Athenaeum, June 7, 1979, 2; Ida Mae Pick, "Concentrate on housing, not stadium," The Charleston Gazette, February 16, 1979, 6A

${ }^{103}$ Jeffrey Mehalic, "Housing code revamped," The Daily Athenaeum, June 12, 1979.
} 
for a good-sized block party." ${ }^{104}$ To remedy this, advocates called for coordination and cooperation between students, University administration, and landlords. ${ }^{105}$

Sectionalism also appeared among WVU's classes. Editorial writer Rick Ridgway, a senior, expressed "apathy" for underclassmen. He foresaw fellow students focusing too heavily on classwork to think about voting and facing landlords for the vote to be effective. "We can tolerate rat-infested, fire trap slums which have neither hot water nor heat during winter...Since most of us at the Athenaeum are seniors, unsafe housing will not be our problem next year. Let the freshmen worry." ${ }^{\prime 106}$ While the Greek perspective is difficult to find, a letter to the editor by Cindy Hunt, mechanical engineering student and Chi Omega president, shows efforts to make changes. She argued that more stringent inspections on Greek housing could be positive for WVU. "If it is true that Student Government and the University have single the Greeks out, then fine," she wrote. "It makes us stronger and more able to defend our rights as a group.",107

Even as students pushed against in loco parentis control, they were not entirely independent from their parents back home. Parents shared concern for the state of student housing at WVU in interviews with local newspapers and letters to the editor. One mother complained that her twin daughters had "rats in the basement, cracks in the windows, peeping toms, and... are always cold." The landlord only turned on the furnace when the mother "called him from Charleston."108 Other parents saw their calls to managers and landlords dismissed. These situations broke trust between the University, alumni, and prospective students. Frances Valko, her husband, and her oldest daughter all graduated from WVU. She had felt "resentful of

104 James Kelly, “A housing code...almost," The Daily Athenaeum, April 27, 1979, 2.

105 Jerry Ash, "Coordination, Not Regulation," The Daily Athenaeum, October 5, 1960, 4.

${ }^{106}$ Rick Ridgway, “Code schmode, apathy in vogue," The Daily Athenaeum, September 6, $1979,14$.

${ }^{107}$ Cindy Hunt, "Underhanded," The Daily Athenaeum, October 31, 1979, 10.

108 “3 Mothers Relate Their Daughters' Housing Troubles," The Charleston Gazette, February 11, 1979, 4A. 
Morgantown and the University" for the housing her oldest daughter lived in as a student. After hearing that housing problems in Morgantown persisted, Valko decided that her youngest daughter would not attend WVU. ${ }^{109}$

Rosemary Bugas of White Sulphur Springs and fellow WVU parents collected 51 signatures for a petition urging Governor Rockefeller to act "as rapidly as possible" regarding the housing problems. Bugas's petition sheds light on shifting parental expectations for universities. The traditional forms of in loco parentis policies involving student behavior were missing. Rather, Bugas criticized the University's behavior in what she considered a serious and fundamental problem in Morgantown. She argued that upperclassmen were "thrown to the wolves," incapable of finding adequate housing. The fault lay not on the students, but on the University and local landlords. As the largest and most prestigious school in the state, WVU should, Bugas argued, be held to higher standards in providing basic amenities for student. She described "old, wooden structures... [with] poor heating, poor plumbing, lack of insulation, dingy and depressing furnishings and finishes, plus overcrowded living conditions" that were not “conducive to [students'] learning.,"110

Often, the question of choice lay at the heart of student housing issues. As students demanded the right to make decisions, both town and gown communities questioned whether students were accepting the responsibilities and consequences that came with such independence. In an interview with The Daily Athenaeum, University Housing Director Robert Robards acknowledged that the quality of local housing was a serious concern, yet critiqued students' aversion to inspections. "Besides," he said, "students don't have to live in substandard housing

\footnotetext{
${ }^{109}$ Frances H. Valko, "Resents Morgantown," The Charleston Gazette, February 17, 1979, 5A.

110 "Statements on Housing at WVU Are Released," The Charleston Gazette, February 15, 1979, 12A
} 
unless they choose to."111 Robards, working with Student Administration and Morgantown officials, was an instrumental part of putting together lists of suggested off-campus housing that met health and safety standards. Although these lists did not solve the root of the problem, Robards rationalized that they informed students of the best options. ${ }^{112}$ Critiques of student choices extended outside the WVU community. Members of the Senate Judiciary Committee determined that students "preferred the lower rent scale of cheaper units" in Morgantown and had to live with what they paid for. ${ }^{113}$ Morgantown landlords who opposed the code also expressed long-term concerns about non-student choices, writing that "[tenants] will no longer have a choice" in having their houses inspected. ${ }^{114}$ Others argued students should choose to take more responsibility of the homes they rented by fixing minor problems and alerting landlords to problems before they passed the point of no return. "Tenants can do a lot to help," wrote Michael Ryan, an associate professor of Journalism at WVU. ${ }^{115}$

Parents like Rosemary Bugas also expressed that going elsewhere was not simple. "That's not the solution," she wrote in her petition. "Many young people want to attend WVU, and they should be offered decent housing in conjunction with top-quality education."116 WVU was the most highly-regarded institution of higher education in West Virginia, and the only one offering graduate and professional studies. ${ }^{117}$

\footnotetext{
${ }^{111}$ Chris Knap, "Student housing: Rents often exceed property value," The Daily Athenaeum, October, 12, $1977,1$.

112 Linda Kubas, “Off-campus housing - teamwork needed?” The Summer Athenaeum, July 9, 1970, 1.

113 "Statements on Housing at WVU Are Released," The Charleston Gazette, February 15, 1979, 12A

${ }^{114}$ Delores J. Moore, "Vote 'No,", The Daily Athenaeum, October 31, 1979, 10; Marcella Williamson, "Housing code impossible to enforce, opponents say," The Dominion Post, November 1, 1979, 1b-2b.

115 Michael Ryan, "Biased reporting," The Daily Athenaeum, October 20, 1977, 10.

116 "Statements on Housing at WVU Are Released," The Charleston Gazette, February 15, 1979, 12A; "3 Mothers Relate Their Daughters' Housing Troubles," The Charleston Gazette, February 11, 1979, 4A.

${ }^{117}$ Lewis, Aspiring to Greatness, 102.
} 
Still, some students acknowledged that they would have to "learn to live with" substandard housing. Ray Betzner, editor at The Daily Athenaeum, wrote that, "Realistically speaking, there simply aren't enough [high quality] apartments to go around. And anyone who says differently hasn't tried to find a place to live." When students would report to fire and health officials, their calls for concern sometimes went unanswered. However, if they were answered, and inspectors visited the house and forced the landlord to comply with "what little laws there are on the books," the student could risk "incurring the wrath of the landlord and possibly [lose] a place to live while repairs are being made." 118

As November approached and student activism picked up speed, the housing code brought local town-gown relationships to the surface. An essential resource for students and citizens alike, housing forced students and local citizens to grapple with questions of University influence in Morgantown. In the 1970s, more than half of Morgantown citizens agreed that students should have "some, but not decisive" influence on local politics, while another quarter felt students should have no influence at all. Their youth could either equip them with refreshing ideas or hinder the wisdom that comes with age. ${ }^{119}$

An exchange between Morgantown's local paper, the Dominion Post, and The Daily Athenaeum helps characterize this town-gown struggle. In early September of 1979, as the referendum vote neared, the Dominion Post published an editorial critiquing WVU voter registration initiatives as efforts to swing local politics too heavily in students' favor. The editorial worried that students did not realize the full extent of registering to vote: that they lost status in their hometowns and became formal residents of Morgantown. Yet the more significant

\footnotetext{
${ }^{118}$ Ray Betzner, "Learning to live with substandard housing," The Daily Athenaeum, October 13, 1977, 8; Chris Knap, "Student housing: Rents often exceed property value," The Daily Athenaeum, October, 12, $1977,1$.

${ }^{119}$ Pride and Drew, As Others See Us, 135-137, 153.
} 
consequences, according to this editorial, went beyond a student's personal change in voter status and warned of its collective impact on the community. "If WVU student so chose, they could capture control of city government, if not Monongalia County offices," the editorial said. “Wasn't this done by University of California students at Berkeley several years ago?” Indeed, Berkeley, home of the Free Speech Movement in 1964-65, possessed its share of radicals who infiltrated existing intuitions, such as the student union and newspaper, while also organizing grassroots efforts to lobby at the university, city, and state levels. ${ }^{120}$ For WVU, a campus with comparatively little political upheaval, The Dominion Post's premonition was radical in itself. While the editorial did not argue students should have no input on the community, the temporary residence of students impacted how much influence they should have in long-term matters. "We can’t believe a majority [of Morgantown citizens] would want part-time, short-term residents...to govern them."121

The Daily Athenaeum editors responded, first clarifying that the Student Administration operated with good intentions; for example, they were actively encouraging students to switch their voter registration back to their home counties after November 9 . They rejected the Dominion Post's claims of a student "takeover" in local government and their use of dramatic imagery of "long-hair protesters chanting slogans and throwing rocks." Instead, they asserted themselves as members of the community, regardless of their voter status, who deserved to have a say in life-or-death matters such as unsafe housing. "Students live here nine months out of the year, and Morgantown property depreciates twelve months out of the year," the editorial argued. "We only want safe housing in Morgantown."122 Although The Dominion Post critiqued student

\footnotetext{
${ }^{120}$ Thelin, A History of American Higher Education, 307-310.

121 The Dominion Post, September 9, 1979.

122 Rick Ridgway, “...then the Code is lost,” The Daily Athenaeum, September 12, 1979, 10.
} 
activism, they agreed that students' passion would "shake longtime Morgantown residents out of their apathy toward voting" and that "well-meaning, serious-minded students," should have a say in local matters. ${ }^{123}$ This demonstrates that the 1979 housing code had far-reaching effects in the Morgantown community.

Students, however, continued to find ways to remind Morgantown citizens of the Mountaineers' influence. As the code vote approached, so did some silent, symbolic gestures from the student community. Students circulated $\$ 2$ bills to remind local businesses of their economic influence. "Not only is the $\$ 2$ bill a novelty, it is a nuisance as well." $" 124$ Perhaps this best captures the challenging town-gown relationships in Morgantown. Students moved seasonally, shifting town populations and activities like migratory birds. Their stay in Morgantown was fleeting, but their influence would remain in the city.

In November 1979, the housing code passed by a narrow margin of 67 votes. $30 \%$ of the registered voters turned up at the polls, considered the busiest local election turnout in recent memory. ${ }^{125}$ Although landlords continued to challenge the code, it took effect on July $8,1980 .{ }^{126}$ Morgantown's mayor, Florence Merow, praised students for their cooperation and involvement with the community. "I don't think of students as students," she said. "I think of them as citizens of the community...Morgantown wouldn't be the same without [them]."127

${ }^{123}$ The Dominion Post, September 9, 1979.

${ }^{124}$ Rick Ridgway, "Silent talkers," The Daily Athenaeum, November 2, 1979, 10; Gerrill Griffith, “\#2 bills show buying power of WVU students," The Dominion Post, November 7, 1979, 8b. 1979,1 ;

${ }^{125}$ John Appezzato, "Voters approve housing code by narrow margin," The Daily Athenaeum, November 7 ,

${ }^{126}$ Jeffrey Mehalic, "Housing code delays end," The Daily Athenaeum, August 21, 1980, 3.

${ }^{127}$ Sue Scancella, "Mayor lauds students' role in community," The Daily Athenaeum, September 4, 1980, 1. 


\section{The Sunnyside Problem and Return of In Loco Parentis?}

Although curfews and strict dress codes were things of the past, questions of student freedom, control, and responsibility remained relevant. In loco parentis disappeared in its traditional form, though current university rules and regulations harken back to this time. ${ }^{128}$ Through interest in off-campus housing, students asserted their membership in the community. They acknowledged their widespread, sometimes overwhelming presence in occasionally candid manners. One student noted that he felt Morgantown was "devoid of children and senior citizens" and looked forward to the "bright smile" of his 11-year-old niece when he returned home. $^{129}$

Off-campus housing issues and remnants of in loco parentis extended throughout Morgantown, though one place that became the epicenter of student-university and town-gown relationships was Sunnyside. Sunnyside, characterized Sunnyside as "Slummyside" in one edition of The Daily Athenaeum, became a standard to gauge the quality of other neighborhoods in Morgantown. ${ }^{130}$ When the City Planning Commission initiated new zoning guidelines in 1979, they did so in hopes that neighborhoods like "South Park do not become Sunnysides."131 This characterization of Sunnyside reveals a negative undertone - that "becoming Sunnyside" was a sign of failure. Although Sunnyside's housing issues persisted for years after the housing code passed, the code did have an effect on the neighborhood. In 1982, one article in The Daily Athenaeum said of the code's influence: “Upperclassmen remember much more substandard

${ }^{128}$ Hoekema, Campus Rules and Moral Community, 4.

${ }^{129}$ Daniel Corey, "Your parents were right about college," The Daily Athenaeum, August 29, 1985, 6.

${ }^{130}$ Amanda Gribble, “Tornados, renovations highlight summer," The Daily Athenaeum, August 20, 1982, 1,10 .

${ }^{131}$ Rick Ridgway, "Revise the Amendment," The Daily Athenaeum, August 30, 1979, 12. 
housing in the area before the Housing Code was adopted." ${ }^{\prime 132}$ Grassroots activism also continued to under the shadow of Sunnyside's persisting negative image. Student groups, including service organizations, Greek fraternities, and dormitory residents, organization cleanups on Earth Day and after block parties. Groups like the Sunnyside Neighborhood Improvement Association involved people at all levels, including businesses, residents, property owners, the city, and University. The city organized a Sunnyside Task Force and sought Community Development funds to renovate sidewalks and install lighting. ${ }^{133}$

Still, the Morgantown community's qualms with Sunnyside became mixed with Sunnyside's emergent student culture. Students, freed of the in loco parentis rules that governed WVU for a century, had new expectations for their "college experience." Sunnyside became the place that offered these experiences. ${ }^{134}$ was hard to pin down, reflected in its convoluted nickname, "the Sunnyside problem / menace / situation / party" by The Daily Athenaeum columnist David Singleton in $1977 .{ }^{135}$ The "Sunnyside problem" became a highly-publicized local talking point amid the period of "retrenchment and reinvention" in universities across the country. ${ }^{136}$ Amongst the deteriorating rental houses, large groups of students threw alcoholfueled parties and burned couches in the streets. These controversial social issues, which played out on a rickety stage, sent alarm throughout the WVU community. Thrust into local spotlight,

\footnotetext{
${ }^{132}$ Susan Jones, "Sunnyside district 'just isn't what it used to be,'” The Daily Athenaeum, November 16, 1982,6 .

${ }^{133}$ Mike Fulton, "Reviving Earth Day," The Daily Athenaeum, April 11, 1978, 8; Sue Scancella, "Task force hopes to beautify Sunnyside, main campus area," The Daily Athenaeum, April 21, 1979; Sam Greco, "SEED sends thanks," The Daily Athenaeum, April 28, 1979, 12; "Grant Avenue gets cleaned up," The Daily Athenaeum, November 16, 1982, 1; Joseph R. Gallen, "Letter to the Editor," The Summer Athenaeum, July 19, 1984, 9-11; Amanda Gribble, "Tornados, renovations highlight summer," The Daily Athenaeum, August 20, 1982, 1, 10; Sharman Peters, "Sunnyside renovation funding difficult to maintain," The Daily Athenaeum, August 27, $1982,1-2$.

${ }^{134}$ Thelin, A History of American Higher Education, 326-327. Although most of the student body entered four-year programs shortly after high school graduation, universities also served students who were part-time, of older demographics, and in two-year programs. With this small yet significant portion of the student body, it was impossible to revive in loco parentis rules governing student behavior.

${ }_{135}$ David Singleton, "Sunnyside's solution," The Daily Athenaeum, September 2, 1977, 8.

${ }^{136}$ Gumprecht, The American College Town, 37-39.
} 
Sunnyside was analyzed as the troubled, rebellious child of WVU and the city of Morgantown.

In the following decades, Sunnyside raised important questions over the rights and responsibilities of various community members in a college town. 


\section{CHAPTER THREE \\ Sunnyside: A Landscape of Personalities and Problems}

By the 1970s, Sunnyside had become a setting of student life. It also became a place that challenged the WVU community to find its identity an increasingly competitive and commercialized system of higher education. For the first time in 25 years, university enrollment declined nationwide. At WVU, enrollment faltered in the 1970s to mid 1980s, as tuition increased and the state struggled to retain its college-age population. While enrollment slowly regained growth in the late 1980s, WVU's problems became more financial, lost millions in state operating funds, struggled to adequately pay faculty and staff, and relied more on student fees. ${ }^{1}$ All the while, WVU faced a less tangible problem: the "\#1 party school" image, which diminished the University's academic successes and entrenched the stereotype of Mountaineers as an uncivilized people.

Like their universities, students also grappled with their personal and collective identities. Following 1960s, the college campus shifted in the public imagination, breaking down traditional in loco parentis structures and rebuilding itself as a center of youth culture. Students, while more socially conscious, also entered universities with individualistic priorities. Facing escalating expenses, burgeoning class sizes, and sprawling campuses, students of the 1970s and 1980s needed perseverance and specific career goals to wade through the quagmire of higher education successfully. They continued to attract media attention, though coverage centered less around political demonstrations and more around a growing party subculture. ${ }^{2}$ Such spectacles hit

\footnotetext{
${ }^{1}$ Thelin, A History of American Higher Education, 326; Gumprecht, The American College Town, 38, 86; Lewis, Aspiring to Greatness, 138, 198-204, 216-217; Weiss, Party School, xvi-xxiii.

${ }^{2}$ Thelin, A History of American Higher Education, 311, 317-321; Horowitz, Campus Life, 220-244, 252255; Lewis, Aspiring to Greatness, 299-311.
} 
mainstream media, such as in the 1974 film Animal House, which typified the spirituous undergrad. The party subculture found on campuses across the United States normalized excess drinking and drug use, risk-taking behaviors, and violence. At WVU, this subculture thrived in Sunnyside, the cultural landscape of the \#1 party school.

Today, WVU fits within the "party school" framework, defined as a public or state university with more than 10,000 undergraduate students, usually between the ages of 18-24, situated within an isolated college town. WVU frequently tops party school lists, the most famous published by the Princeton Review. Criteria for these rankings are relatively unscientific, using student perceptions of alcohol consumption, drug use, Greek life popularity, and amount of time spent studying to gauge the level of partying. ${ }^{3}$ Still, these rankings continue to have a significant effect on the culture of higher education. Every year the lists are published, universities from across the country respond with shock, exasperation, or deep concern. The lists, though often dismissed as phony measurements of university quality, still challenge universities to grapple with their public image. ${ }^{4}$ At WVU, President Gordon Gee, though encouraging students find a balance between work and play, asserts, "We are not a party school. Let me say that again. We are not a party school." ${ }^{5}$

Approaching Sunnyside through the lens of the party school image offers a number of interpretive opportunities. It allows Sunnyside to be set within the social and cultural context of the 1970s and 1980s. The party school image sent reverberations through the WVU community that deserve closer attention. In particular, this party school image sheds light on the "Sunnyside

\footnotetext{
${ }^{3}$ Weiss, Party School, xv-xvi.

4 Avi Wolfman-Arent, "WWe're No. 2!' And Other Ways to Respond to 'Party School' Fallout," The Chronicle of Higher Education, August 6, 2014 http://www.chronicle.com/blogs/ticker/were-number-2-and-otherways-to-respond-to-party-school-fallout/83409

${ }^{5}$ University Relations/News. "A university on the rise: Gee shares 'big ideas' for WVU, its partners," WVU Today, October 6, 2014, accessed April 24, 2017, http://wvutoday-archive.wvu.edu/n/2014/10/06/auniversity-on-the-rise-gee-shares-big-ideas-for-wvu-its-partners.html
} 
problem." Concerns for Sunnyside in the late twentieth century involved more than the roofs over students' heads. It intersected with students' identities as independent young adults. Working in tandem, the "party school" image and the "Sunnyside problem" inform discussions of student activities, the cultural meanings of Sunnyside, and contemporary discussions of revitalization. They reflect how WVU as an institution and students, individually and collectively, shaped their identities in a time when higher education thrived on future aspirations more than reputations of the past.

Student writings provide an insider perspective on the labels assigned to their university and Sunnyside, a place that could be their home, their favorite hangout, or simply a neighborhood they walked by on their way to class. Some students conceptualized Sunnyside as an integral aspect of their "WVU experience." In particular, this "experience" centered around alcohol and partying that attracted local and nationwide attention. The conversations that emerged around alcohol were really conversations on student rights, responsibilities, and questions of adulthood. By looking back on discussions in the 1970s and 1980s, Sunnyside sheds light on the complexities of a cultural landscape where its occupants are more transient than its issues. $^{6}$

\section{Sunnyside: The Landscape of America's \#1 Party School}

The origins of the "\#1 party school" label are uncertain; some sources point to rumors that began in the 1970s, "off the cuff remarks" made at a subcommittee meeting in the mid1980s, and the popular Lisa Birnbach's College Book (1984), which argued there was “more

\footnotetext{
${ }^{6}$ Carla Yanni, "Campus History at the Crossroads: Three Divergent Methods," Journal of Planning History, Vol 11, No. 4 (2012): 349.
} 
pressure to party than to study" at WVU. ${ }^{7}$ Although its origins are mythical, the label's implications have been real. The label shaped public perception of WVU and compelled damage control from the highest levels of WVU administration and state legislators. ${ }^{8}$ Thereafter, the "\#1 party school" image proved to be a constant thorn in WVU's side. The varying interpretations of this label shed light on the image WVU wanted to present. They also enlighten conversations on Sunnyside, the landscape of the \#1 party school. Understanding the connections between this label and Sunnyside inform WVU's conceptions of identity and, later, how Sunnyside became the target of modern revitalization efforts.

Sunnyside in the 1970s and 1980s comprised a bustling community of student tenants, visitors, and passersby. Students walked along Old Mountaineer Field's Stadium Bridge to enter and exit WVU's Downtown campus. ${ }^{9}$ In late afternoons and evenings, students finished with their classes flooded the streets of Sunnyside. Weekends were especially crowded. Sunnyside's "main attraction" for residents and non-residents alike was alcohol. ${ }^{10}$ They frequented taverns including Mutt's, The Vagabond, the Stadium Inn, the College Inn, Finnerty's, Redbeard's, and Dr. John's. ${ }^{11}$ These businesses provided a unique service to WVU students. As one WVU board member noted, "Sunnyside was the only place left where students can drink beer in a college atmosphere." 12

Sunnyside's streets were also ideal for block parties. Although consisting of a steep, hilly landscape, streets in Sunnyside lay in a logical grid pattern flanked by closely-built frame houses

${ }^{7}$ Lisa Birnbach, Lisa Birnbach's College Book, (New York: Balletine Books, 1984), 424.

8 "Party school," The Daily Athenaeum, August 29, 1985, 6; "Yale guide," The Daily Athenaeum, September 12, 1985, 4; Trish Prospero, "Every school is a party school," The Summer Athenaeum, July 18, 1985, 5.

9 Jon Schmitz, "Close down Stadium Bridge," The Daily Athenaeum, October 20, 1977, 10.

${ }^{10}$ Ray Betzner, "Sunnyside's suicide," The Summer Athenaeum, May 26, 1977, 4.

${ }^{11}$ Nick Thimmesch II, "Morgantown bars serve local stars, but not out of jars," The Daily Athenaeum, June 7, 1979.

12 "Directors consider Sunnyside conflict," The Daily Athenaeum, September 2, 1977. 
with porches and front lawns. On weekends, and sometimes throughout the week, in the fall and spring, Sunnyside transformed into the "bonfire capital of WVU."13 Students dragged couches, chairs, dressers, fences, signs, and clothing into the street, igniting one-to-two dozen fires per year until the 1990s. These activities coupled with safety concerns such as deteriorating houses, blocked roads, unlit streets, and crimes including property damage, noise, trespassing, underage drinking, and assault. Some residents expressed they were afraid to leave their houses at night and worried if police would answer their frequent calls. Sunnyside, therefore, comprised a distinct set of activities that characterized Morgantown's student neighborhood. ${ }^{14}$

Exploring the party school image through the lens of Sunnyside allows for a more nuanced understanding of the larger "Sunnyside problem." Parties in Sunnyside became the primary talking point at Board of Governors and City Council meetings early in the fall semester of 1977 , a few years before the "party school" image made local headlines. ${ }^{15}$ Although Sunnyside was not University property, the magnitude of partying and the level of safety concerns obligated the University to step in. At its simplest, students gathered at taverns or threw modest house parties among friends. At its most dramatic, thousands of students staged block parties, a spectacle that filled Sunnyside's long streets, trampled lawns, and cramped houses.

${ }^{13}$ Terri Weimer, "Any Occasion Makes Way for a Celebration,” Monticola, 1983, 42-43.

${ }^{14}$ Jon Schmitz, "Beer ban bomb," The Daily Athenaeum, August 25, 1977, 12; John Schmitz, "Sunnyside problem discussed: Board suggests police action," The Daily Athenaeum, September 8, 1977, 1; Jeff LiButti, "Letters: On Sunnyside," The Daily Athenaeum, April 26, 1979, 12; Jeff Bair, "City not harsh to University," The Daily Athenaeum, September 19, 1985, 1-2; Brad Dilling, "Sunnyside affected by changes," The Summer Athenaeum, May 28, 1986, 20; "All talk no action regarding assault," The Daily Athenaeum, September 16, 1986, 4; Schuyler Kropf and Eric Maclure, "Hydrant soaks fans' bonfires," The Daily Athenaeum, October 30, 1984, 1, 10; Bryan Bumgardner, "Couch fires really a true WVU tradition," The Daily Athenaeum, December 5, 2012, http://www.thedaonline.com/article_5ec897ac-0002-52ca-846f-cc008f4a428b.html; Lewis, Aspiring to Greatness, 484; Weiss, Party School, 99-114.

15 "Directors consider Sunnyside conflict," The Daily Athenaeum, September 2, 1977; Val Neiman, "Sunnyside tops council agenda," The Daily Athenaeum, September 7, 1977, 1. 
More student arrests took place in Sunnyside than anywhere else in Morgantown. ${ }^{16}$ Its distinct issues reflect national problems that persist today in student conduct and their relationships with universities and surrounding towns. ${ }^{17}$

The party school label shaped how the WVU community handled its public image. The conversations surrounded a few repetitive themes: ambiguity around what a "party school" looked like, a lack of "real evidence," the normalization of party subculture at universities nationwide, and other successes and failures at WVU that deserved greater attention. Accusations of WVU's party school image became especially more pressing as the West Virginia legislature considered cutting funds to WVU until problems resolved. ${ }^{18}$

The WVU community used lack of evidence to brush off the "party school" image as a baseless rumor. The Board of Regents argued that there wasn't "any truth to the notion that there is more partying than academics," but at the same time, had no measurements of these activities. ${ }^{19}$ Nonetheless, publications like Lisa Birnbach's College Book publicized the party school image and, in turn, served as a source of “evidence” for the image. Lisa Birnbach's College Book, a handbook published by writer Lisa Birnbach in 1984, illustrates how a publication characterized WVU to an audience of prospective college students. In the 1980s, Birnbach traveled to 186 American colleges and universities and "looked at the social life, the atmosphere, the political climate, the guys, the girl, and the clothes at every school," rather than

\footnotetext{
16 Jan Bamford, "Nine arrested at Grant party," The Daily Athenaeum, August 28, 1985, 4-5; Mike Vogel, "24 weekend partiers arrested," The Daily Athenaeum, September 23, 1980, 1-2; Terri Weimer, "Any Occasion Makes Way for a Celebration," Monticola, 1983, 42-43.

${ }^{17}$ Gumprecht, The American College Town, 298; Ray Bromley, "On and Off Campus: Colleges and Universities and Local Stakeholders," Planning, Practice \& Research, Vol. 21, No. 1 (February 2006): 8-10.

18 "Party school imagery - a reason or an alibi," The Summer Athenaeum, July 18, 1985, 6; Trish Prospero, "Every school is a party school," The Summer Athenaeum, July 18, 1985, 5.

${ }^{19}$ Christopher Kersey, "University 'party school' image exaggerated," The Daily Athenaeum, August 23, 1985, 5.
} 
purely academics. ${ }^{20}$ Her narrative on WVU heavily emphasized the party scene. While most school profiles included some discussion of student partying and drinking, WVU's profile stressed an unmatched "pressure to party." Parties, the profile argued, were how poor and firstgeneration West Virginian students could laugh and smile, their eight-day schedules built around a continuous pattern of drinking, hangovers, and recovering. Although the profile acknowledged this reputation was "not an advantage to all members of this community," it mentioned no other recreational activities available to students. Comparatively, profiles on WVU's biggest rivals, University of Pittsburgh and Pennsylvania State University, discussed their respective party scenes, while still highlighting the universities' distinguished departments, athletic success, and school spirit. ${ }^{21}$ Members of WVU community responded to this publication, arguing that Birnbach's characterization of WVU was biased, shortsighted, and sensationalized. ${ }^{22}$ WVU Student Administration vice president, Pat Mason, critiqued her interpretation: "Instead of painting the real picture of West Virginia University as a fine academic institution, she painted it with the old myth of a party school., ${ }^{, 23}$ Lisa Birnbach's College Book not only perpetuated this myth, but publicized it to a wide audience of young people and their families on the college search.

Sometimes, fellow universities supported the party school image in their publications. In 1985, The Insider's Guide to the Colleges, published by The Yale Daily News, wrote that WVU was only a place for socializing. The Daily Athenaeum accused the paper of haphazard research, speaking only to "one or more" students whose stories represented a student body of more than

\footnotetext{
${ }^{20}$ Birnbach, Lisa Birnbach's College Book, xv.

${ }^{21}$ Birnbach, Lisa Birnbach's College Book, 422-424, 323-325, 333-334, 354,

22 "Party school imagery - a reason or an alibi," The Summer Athenaeum, July 18, 1985, 6; Trish Prospero, "Every school is a party school," The Summer Athenaeum, July 18, 1985, 5.

${ }^{23}$ Trish Prospero, "Every school is a party school," The Summer Athenaeum, July 18, 1985, 5.
} 
18,000. They argued that these anecdotal stories "hardly give one an objective and complete perspective on an issue as complex as the very nature of a university." 24

Still, even those who defended the University's prestige did not deny that WVU students liked "to have a good time.", 25 To maintain WVU's credibility, they placed partying within a broader context of normal college life. Students, their parents, and University administrators alike were quick to argue that the usual weekend parties were not unique to WVU. Simply put, "every school [was] a party school."26 Although the contemporary conception of a "party school" only developed in the late twentieth century, American universities inherited long histories of student conduct issues, ranging from mild pranks to violent riots. While some of these activities stemmed from specific grievances with the university, others were recreational activities born from undergraduate subcultures in Greek organizations and off-campus spaces. Alcohol often fueled unusual fads and crazes and escalated deviant behaviors such as gambling, hazing, promiscuity, and male-dominated aggression. Party schools like WVU inherited these histories, which, by the 1970 s, were no longer mitigated by in loco parentis policies. ${ }^{27}$ As the party school label headlined The Daily Athenaeum in the mid-1980s, defenders frequently invoked this party precedence to explain issues at WVU. "There is partying at all schools," parents were quoted in The Daily Athenaeum. "You'll find it everywhere."28

\footnotetext{
24 "Yale guide," The Daily Athenaeum, September 12, 1985, 4; Trish Prospero, "Every school is a party school," The Summer Athenaeum, July 18, 1985, 5.

${ }^{25}$ Trish Prospero, "Every school is a party school," The Summer Athenaeum, July 18, 1985, 5.

${ }^{26}$ Trish Prospero, "Every school is a party school," The Summer Athenaeum, July 18, 1985, 5

${ }^{27}$ Sloan and Fisher, The Dark Side of the Ivory Tower, 7-26; Horowitz, Campus Life, 24-55; Syrett, In the Company He Keeps, 262-284; Students of the eighteenth and nineteenth century cheated on tests, engaged in hazing, enacted physical violence upon university staff, faculty, and fellow students. Historians have argued that the maledominated history of higher education has perpetuated distinct forms of male-dominated violence, such as fights and sexual assault.

${ }^{28}$ Christopher Kersey, Charlene Van Hook, and Trish Prospero, "Frosh defy critics," The Summer Athenaeum, July 18, 1985, 5
} 
Some students disagreed that this was the case, worrying about the broader effects this image could have on WVU. One editorial in The Daily Athenaeum wondered, "Imagine how parents of graduating high school students are going to react when little Bobby and sweet Susie tell them they'd like to further their education in Morgantown next fall...the shame of it all is that the University's image within the state has been damaged." 29 Parents who felt "reluctant" at first to send their children to WVU were more "reassured" when they arrived in Morgantown, arguing that the level of partying had been blown out of proportion. ${ }^{30}$ The image, while it did not fully deter enrollment or break WVU's reputation, was part of broader conversations about the character of WVU's student body.

Others felt that the party school image publicity distracted from WVU's successes as well as its failures. In the late 1970s and 1980s, WVU achieved various levels of success. The University was deemed a "competitive" institution, with a growing honors program, a reaccredited set of doctoral programs, and a high number of Fulbright Scholars, Truman Scholars, and Rhodes Scholars. The University also made strides toward improved social justice for students of color, students with disabilities, and female students, and attracted promising students from around the world. ${ }^{31}$ These successes, critics argued, should have outshined the party school image.

Conversely, the party school image diminished more pressing issues at WVU, such as course waitlists, rising tuition, falling enrollment, instructor salaries, and dated technology and equipment. ${ }^{32}$ One letter to the editor in The Daily Athenaeum observed that students appeared

\footnotetext{
29 "Party school," The Daily Athenaeum, August 29, 1985, 6.

${ }^{30}$ Christopher Kersey, Charlene Van Hook, Trish Prospero, "Frosh defy critics," The Summer Athenaeum, July 18, 1985, 5 .

${ }^{31}$ Christopher Kersey, "University 'party school' image exaggerated," The Daily Athenaeum, August 23, 1985, 5; "Yale guide," The Daily Athenaeum, September 12, 1985, 4; Trish Prospero, "Every school is a party school," The Summer Athenaeum, July 18, 1985, 5; Lewis, Aspiring to Greatness, 270-275, 299.

${ }^{32}$ Christopher Kersey, "Party image gets too much notice," The Summer Athenaeum, July 18, $1985,5$.
} 
more dedicated and "concerned with making the grade" in a time when "economic reality makes a good GPA and a diploma too valuable to risk., ${ }^{, 33}$ Outside academia, students advocated for more support from the University on social issues, such as sexual assault cases, which some students felt were mishandled and underreported. ${ }^{34}$ These arguments demonstrate how the party image waxed and waned in significance and was weighed against other issues taking place on campus.

Participants in these discussions hashed it out in local media coverage, which in itself became controversial. Some critics argued that news coverage sensationalized the party school image, a tactic that perhaps sold more newspapers but failed to address the serious problems WVU faced. ${ }^{35}$ One editorial in The Daily Athenaeum highlighted this double standard, calling the controversy "partygate" and lamenting that the University would spend years dealing with such reputational fallout. "If half the concern expressed over the social life of University students had been focused into solving the academic and physical problems from which they suffer, the University would be well on its way to regaining some of its reputation of providing a quality education," the editorial argued. ${ }^{36}$

There was no singular perspective on the "party school" image when it appeared in the 1980s. Even those who disagreed over whether the "party school" image was appropriate drew similar conclusions on the school's integrity. Interim President Diane Reinhard acknowledged that "a school where students like to celebrate when they're finished with their work" was not a "party school," but rather a place where students could balance both academic and

\footnotetext{
33 "Students more dedicated," The Summer Athenaeum, August 1, 1985, 7.

34 "No talk, no action," The Daily Athenaeum, September 16, 1986, 4.

35 "Party school," The Daily Athenaeum, August 29, 1985, 6; "University scholars have real 'love fest' at party-image hearing," August 28, 1985, 1; Christopher Kersey, "Party image gets too much notice," The Summer

36 "Party school," The Daily Athenaeum, August 29, 1985, 6.
} Athenaeum, July 18, 1985, 5. 
extracurricular life. ${ }^{37}$ Learning to balance work and play, she argued, was an integral life skill that would benefit students long after graduation. ${ }^{38}$ Students like Jeff Ritchie agreed that WVU's “incongruous" reputation of partying and academics should be embraced. "WVU is obviously a school which has proved that an active social life does not preclude a healthy academic life," he wrote. "Most of the people who you see out drinking at 11:00 were probably working at a parttime job at 4:00 and studying at 8:00. There's a time and a place for everything, and WVU students have learned that." ${ }^{39}$ Students' abilities to make such decisions were critiqued in Sunnyside, where the level of partying seemed to confirm the party school image.

The party school image, therefore, challenged the WVU community to wrestle with its reputation as an individual institution and among other universities. Sunnyside became a distinct component of these conversations about the University, as well as beyond the boundaries of higher education. On the first day of classes in August 1985, for example, students held a party along Grant Avenue, which gathered a crowd of 1,500 students by midnight. "With the party school image...the students did themselves no favor," Police Chief John Cease said, reflecting how student parties impacted more than the University community, but police, firefighters, and local citizens. ${ }^{40}$ As one student noted, Sunnyside was "as much a city menace as it [was] a campus problem."41

${ }^{37}$ Trish Prospero, "Every school is a party school," The Summer Athenaeum, July 18, 1985, 5

${ }^{38}$ Christopher Kersey, "University 'party school' image exaggerated," The Daily Athenaeum, August 23, $1985,5$.

39 Jeff Ritchie, "Morgantown Students Budget Time," The Daily Athenaeum, August 21, 1986, 4A.

${ }^{40}$ Jan Bamford, "Nine arrested at Grant party," The Daily Athenaeum, August 28, 1985, 5.

${ }^{41}$ Mary Ellin Arch, "Supermeeting," The Daily Athenaeum, September 9, 1977, 12. 


\section{The Sunnyside Spirit: Student Conceptions of Behavior in Sunnyside}

In October 1984, WVU Mountaineers broke a 29-year losing streak against the Penn State Nittany Lions, sending 6,000 students into the streets of Sunnyside. ${ }^{42}$ In a letter to the editor in The Daily Athenaeum, Beth Rais, a second-year law student, questioned what a WVU Mountaineer should look like. She argued that students" "obnoxious conduct" worked to “enforce our 'hillbilly' image and destroy our credibility." ${ }^{43}$ A few months earlier, in July, attendees at the 1984 commencement criticized similar "childish" and "not becoming" behavior of graduates, who were loud and intoxicated. The writer noted, "Students decided to display a touch of the Sunnyside spirit."44 These incidences demonstrate the WVU community's concerns for its image. When the Mountaineer, a figure of nineteenth century Appalachian folklore became the University's official mascot in 1937, the WVU community had to consider which iteration of the figure the mascot would represent: a "hillbilly" caricature, depicted as poor, ragged, and wild, or a modern mountaineer, whose strength, resourcefulness, and independence made him or her capable of surviving in the wilderness. ${ }^{45}$ According to Rosemary Hathaway, WVU students, in a formative time in their lives, used the Mountaineer's image to "explore the intersections between their past identities and the new ones they were creating." ${ }^{46}$ Similarly, students also embodied the "Sunnyside spirit," embracing the behavioral characteristics associated with one place in Morgantown to shape their identities as WVU students.

\footnotetext{
${ }^{42}$ Schuyler Kropf, "Behavior criticized," The Daily Athenaeum, October 30, 1984, 1; Schuyler Kropf and Eric Maclure, "Hydrant soaks fans' bonfires," The Daily Athenaeum, October 30, 1984, 1

${ }^{43}$ Beth Rais, "Unbecoming conduct," The Daily Athenaeum, October 30, 1984.

${ }^{44}$ Sati Maharaj, "Grads act like 'children,"” The Summer Athenaeum, July 12, 1984, 1.

${ }^{45}$ Hathaway, "From Hillbilly to Frontiersman," 15-16, 24, 28, 40-42; C. Belmont Keeney, "Soldiers and Stereotypes: Mountaineers, Cultural Identity, and World War II," PhD Dissertation (West Virginia University, 2009), 2-5, 88-90; Lewis, Aspiring to Greatness, 105-109; John Lloyd Retzer, "Celebration of pride: a historical view of its traditions," The Daily Athenaeum, Oct. 30, 1984, 8; The Mountaineer has been WVU's official mascot since 1927. Envisioning the Mountaineer has also included discussions of gender. Only two women have portrayed the Mountaineer.

${ }^{46}$ Hathaway, "From Hillbilly to Frontiersman," 40.
} 
Usually fueled by alcohol and school spirit, this behavior became the hallmark of WVU's image as the "\#1 party school" in the 1980s. The Mountaineer mascot, whose complicated yet integral history continues to shape identities of WVU students, serves as a comparative model for the Sunnyside spirit. Like the Mountaineer, Sunnyside entered the lore of West Virginia University and defined the "student experience." It also concerned WVU community members who worried about the University's reputation. The Sunnyside spirit helps frame understandings of student behavior and its effects on student-university and town-gown relationships. By focusing on the 1970s and 1980s, when WVU first began to grapple with the Sunnyside problem and party school image, a nuanced image of how students conceptualized the Sunnyside spirit emerges.

University life presented a distinct culture that challenged young adults to balance their newfound freedom with mature responsibilities. Students rationalized their fun in Sunnyside in a multitude of ways. Three reasons stand out. First, students used Sunnyside as a place to express their freedom and independence. Second, students saw themselves as participating in integral traditions closely intertwined with the WVU "student experience," contributing to a "process of cultural construction" that characterizes Sunnyside today. ${ }^{47}$ Third, students, in acknowledging their freedom and traditions, romanticized the activities in Sunnyside, even those considered dangerous and deviant.

Students like Jeff LiButti, a psychology and business sophomore, paint a picture of student behaviors. In April 1979, LiButti participated in a party on University Avenue after the winter weather broke and finals loomed in the following weeks. Students dragged furniture and clothing out into the street and piled them into a "glorious bonfire in the middle of University

\footnotetext{
${ }^{47}$ Christopher Shaw and Malcom Chase, The Imagined Past: History and Nostalgia (Manchester: University of Manchester Press, 1989), 10-14.
} 
Avenue." The air filled with smoke, flying bottles and cans, and the noise of more than 3,000 participants shouting, chanting, and cheering. Students scaled a fire truck like "a jungle gym" and played tug-of-war with a firehose. He ended his letter to the editor with an acknowledgement that these behaviors, some illegal, would obviously continue. There were "whispers around campus" that the bonfire would become a tradition. "Students better bring hard hats and crash helmets in case of a police-student confrontation," he wrote. "As for myself, I'll bring the marshmallows for the fire!" 48

LiButti's testimony reflects the Sunnyside spirit. Sunnyside had provided him and 3,000 fellow students with an opportunity to express their individual freedoms and well as collective freedoms of the college party lifestyle. His focus on excitement and humor demonstrate how Sunnyside's culture permitted activities that would have not been acceptable in other contexts. His indication that street bonfires would become an annual activity illustrates the enthusiasm behind creating and perpetuating college traditions. Lastly, LiButti wrote his testimony in a playful, romantic tone, dismissive of potential dangers that accompany reckless behavior. Even when acknowledging that the bonfire had gotten out of hand, "licking the powerlines above," he described the overall atmosphere as "a bit humorous." "49 The potential benefits of a memorable night in Sunnyside, especially for upcoming graduates, outweighed potential risks, a pattern visible in party subculture. ${ }^{50}$

Alcohol consumption was a significant component of Sunnyside's culture that helped students conceptualize freedom as young adults. Though it may appear historically insignificant, it is integral to interpreting how students conceptualized their experiences as WVU students.

\footnotetext{
48 Jeff LiButti, “Letters: On Sunnyside," The Daily Athenaeum, April 26, 1979, 12.

49 Jeff LiButti, “Letters: On Sunnyside," The Daily Athenaeum, April 26, 1979, 12.

${ }^{50}$ Weiss, Party School, xxii-xxiii; 38-115;
} 
When examined critically, college drinking is a powerful social and cultural phenomenon that affects student identities. ${ }^{51}$ Students closely associated alcohol and Sunnyside, as shown in an opening hook of one Daily Athenaeum article: "Alcohol is a) something one buys at a bar in Sunnyside, b) a food, c) a drug. The correct answer is all three."52 One student compared Sunnyside's bars to novel forms of Greek life within student culture: "Perhaps it is more important to sample all the bars than it is to sample all the fraternities." ${ }^{, 53}$ Although large-scale parties received heavy press coverage, most partying took place on a smaller scale and in more private spaces. After the West Virginia drinking age was lowered to 18 in 1972, 91\% of WVU students admitted they drank, primarily for social reasons and to relieve stress. Some students saw Sunnyside as not a symptom of problems but as a treatment. They frequented Sunnyside's bars to "make student life a little more bearable" and unwind after a day of arduous classwork. ${ }^{54}$ Students had strong reactions to changes in local and state laws that limited alcohol consumption, perceiving these efforts as limiting their freedoms. In 1977, a citywide ordinance prohibited the possession and consumption of beer in outdoor spaces. With its passage in November, the ordinance put countless students in violation of local law and put Sunnyside in the local spotlight. Students and police clashed not only over the law, but also over fundamental issues about controlling the "Sunnyside spirit." On the first weekend the ordinance was enforced,

\footnotetext{
${ }^{51}$ Ibid., 38; Henry Wechsler, Harry and Bernice Wuethrich. Dying to Drink: Confronting Binge Drinking on College Campuses (Rodale, 2002), 3-4; Andy Soon Leong Tan, “Through the Drinking Glass: An Analysis of the Cultural Meanings of College Drinking," Journal of Youth Studies, Vol. 15, No. 1 (February 2012):

52 Steve Hall, "Alcohol has good, bad effects," The Daily Athenaeum, November 28, 1979, 1.

${ }^{53}$ Daniel Corey, "Your parents were right about college," The Daily Athenaeum, August 29, $1985,6$.

54 Terri Weimer, “Any Occasion Makes Way for a Celebration,” Monticola, 1983, 42-43; Comparatively, business owners on High Street did not feel the "party image" reflected their part of town. More frequented by Morgantown residents and University professionals, these businesses felt the undergraduate students who visited their bars sought a more "relaxed" and "laid-back" atmosphere than what was found in Sunnyside. See Jeff Bair, "Students don't party downtown, merchants say," The Daily Athenaeum, September 18, 1985, 9.
} 
65 partiers were arrested, 38 of whom were under the new law. ${ }^{55}$ Whether the "beer ban" would have positive effects on student drinking issues in Morgantown was more up for debate than the visible increase of police presence that it initiated. City police flocked to Sunnyside, their "main objective" being to enforce the ordinance. ${ }^{56}$ This police presence was not always welcome.

The Daily Athenaeum coverage of student-police relationships reveals how image mattered to both parties involved. For example, in 1977, after the beer ordinance went into effect, student media and the police came head to head. Photographs of the ruckus appeared in The Daily Athenaeum, documenting through imagery and photographer testimony the complex relationships taking place in Sunnyside. Student photographers found themselves under fire, remarking that police seemed suspicious of their cameras and threatened to break their cameras. ${ }^{57}$ The Daily Athenaeum's critical coverage reflects its tagline: "Little good is accomplished without controversy, and no civic evil is ever defeated without publicity.",58

Student-police relationships were in flux throughout the 1970s and 1980s, with each year seemingly as unpredictable as the next. Police presence increased especially around football games and the beginning and end of the school year when large parties took place, making them a powerful and visible component of the Sunnyside spirit. Because of this, police drew criticism from outside the WVU community, too; an editorial in Morgantown's newspaper, The Dominion Post, claimed the police allowed "law breakers [to get] away free" and should show "aggressiveness to restore law and order." ${ }^{59}$ However, the city police's mantra in the 1970s and

\footnotetext{
${ }^{55}$ Valerie Nieman, “City beer ordinance may soon be reality,” The Daily Athenaeum, October 5, 1977, 1; Jon Schmitz, "Sunnyside: Arrests bring praise, criticism of police actions," The Daily Athenaeum, November 8 , 1977, 1-2; Stephen Paesani, "Student Control," The Daily Athenaeum, October 14, 1977, 12.

${ }^{56}$ David Rodgers, "Police vow to enforce beer rule," The Daily Athenaeum, August 27, 1980.

${ }^{57}$ John Schmitz, "Sunnyside: Arrests bring praise, criticism of police actions," The Daily Athenaeum, November 8, 1977, 1.

${ }^{58}$ The Daily Athenaeum, November 8, 1977, 1.

59 "Street disturbances need tough response," The Dominion Post, April 24, 1979, 10 A.
} 
1980s was one of peacekeeping and restraint. They worked on developing a "positive relationship" with the student community in Sunnyside. They employed strategies such as strategically placing the same officers on patrols and preferring to issue tickets rather than make arrests. ${ }^{60}$ Some students appreciated these cooperative efforts, one saying, "We may be like dogs on a leash, but it's a very long leash." ${ }^{\prime 1}$

An exchange regarding a cartoon in The Summer Athenaeum captures these contentious issues. In 1984, City Manager Doug Fawcett questioned whether The Summer Athenaeum chose an appropriate cartoon to accompany an article discussing improved town-gown relationships. The cartoon featured "a police officer...wearing a visored riot helmet and holding a billyclub...standing at the corner of University Avenue and Campus Drive." The officer's gear and his position at the entrance of Sunnyside suggested, according to Fawcett, "that the City's general policy of addressing crowd control and other problems in the Sunnyside area is one of force and intimidation." ${ }^{62}$ His response suggests that the cartoon's negative tone darkened the optimism of improved town-gown relationships in the article. During this time, officers patrolling Sunnyside were "getting to know" the students, and the chief officer assured residents that they "don't send officers out to stir up trouble."63

In response, the editor of The Summer Athenaeum defended their use of the cartoon.

While appreciating the efforts for improved town-gown relationships, the editor argued the

${ }^{60}$ Schuyler Kropf, "Sunnyside beat officers ease tensions, add security to area," The Daily Athenaeum, October 17, 1984, 6; Schuyler Kropf, "Street officers secure safe Sunnyside," The Daily Athenaeum, October 18, 1984, 6; Schuyler Kropf, "Police shouldn't intimidate Sunnyside crowd, Cease says," The Daily Athenaeum, August 30, 1984; Jennifer Michels, "Incident leaves police angry with students," The Daily Athenaeum, August 28, 1986, 3.

${ }^{61}$ Schuyler Kropf, "Sunnyside beat officers ease tensions, add security to area," The Daily Athenaeum, October 17, 1984, 6 .

${ }^{62}$ Doug Fawcett, "Letter to the Editor," The Summer Athenaeum, August 2, 1984, 9.

${ }^{63}$ Laura Kauper, "University and city officials agree on improving image," The Summer Athenaeum, July 26, 1984, 8-9; Jennifer Michaels, "Incident leaves police angry with students," The Daily Athenaeum, August 28, 1986,3 . 
cartoon in juxtaposition with the article provided "an accurate presentation of issues both positive and negative." "If you would ask 10 students what symbolizes the WVU-City relationship in their mind," the editor wrote, "more than half would point to the policeman patrolling Sunnyside."64 The editor's rhetorical use of this evidence, despite its highly anecdotal nature, demonstrates that the police officer "image" was significant and prominent to the student community in Sunnyside. By defending the cartoon, the editor sought to make the student perspective more visible. This interaction between the City Manager and The Daily Athenaeum brings nuance to a complicated issue.

When the drinking age rose to 21 in 1986, students again were forced to confront their rights and responsibilities. Like the beer ordinance, the drinking age put 17,500 students in potential violation of the law. Sunnyside's bars responded by emphasizing food service, so that they could continue attracting and profiting from the college age crowd. In turn, they faced more issues of fake identification and closer observation from local police. ${ }^{65}$ Students grappled with their limited freedoms, wondering how they would redefine their student experiences now that a major component was illegal.

Articles in The Daily Athenaeum shed light on how students oriented themselves amid these legal changes. They depicted fictional characters like "Joe College" and "Al Kohol" grieving and confused, struggling to imagine what places Sunnyside would look like without their biggest supporters. ${ }^{66}$ Recognizing that alcohol consumption was a significant part of college life, one editorial argued that the drinking age law took "no consideration...to the social lives" of

${ }^{64}$ Editor's note to Doug Fawcett, The Summer Athenaeum August 2, 1984, 9.

65 "U trying to slow underage drinkers," The Daily Athenaeum, August 23, 1986, 1A, 3A; Mary Coupe, "Switch 'hasn't affected' area bars," The Daily Athenaeum, August 23, 1986, 1A, 3A; "Not so wild anymore," The Daily Athenaeum, August 28, 1986, 4.

${ }^{66}$ Beverly Weatherholt, "Six More Days to Drink: New Drinking Age July 1," The Summer Athenaeum, June 25, 1986, 1; "Not so wild anymore," The Daily Athenaeum, August 28, 1986, 4. 
WVU's now-underage students. Instead, the law presented students with "the question of how to spend their weekend nights." ${ }^{, 67}$ According to some, however, this was a question students should seriously consider. The director for the Department of Public Safety at WVU, Captain William Strader, suggested that the law could help students transition more readily into adulthood. "Young people have to grow into manhood or womanhood," he said. "It's part of growing up.,"68 Whether students wanted to grow up was still up for debate. Some students conceptualized their freedom in college as extended youth, rather than a step into adulthood.

Not all students felt that alcohol was central to the WVU experience or their identities as Mountaineers. These opposing perspectives reflect how students rationalized the responsibilities that accompanied young adult freedom. Students like Nancy Martin argued that "higher education means books, not beer mugs." While she "learned to drink at the College Inn," a bar in Sunnyside, and she would continue drinking even after the law passed, Martin argued that WVU's parties should not overshadow what truly made the University an attractive institution. She emphasized WVU's educational feats, such as how programs prepared students for graduate school, the diverse fields of study, and successes of WVU alumni. "[Drinking] has nothing to do with my being a student at WVU," she proclaimed, "and please don't tell me that it does because that is what everyone who feels the need to insult WVU wants to hear." ${ }^{, 69}$ Furthermore, not all drinking occurred at will; half of students who drank in the 1970s admitted that they caved to peer pressure and drank more than they wanted at least once a month. ${ }^{70}$ These perspective show

67 "Not so wild anymore," The Daily Athenaeum, August 28, 1986, 4.

68 "U trying to slow underage drinkers," The Daily Athenaeum, August 23, 1986, 1A,3A.

${ }^{69}$ Nancy J. Martin, "Response to Sunnyside," The Summer Athenaeum, July 16, 1986, 5.

${ }^{70}$ Steve Hall, "Alcohol has good, bad effects," The Daily Athenaeum, November 28, 1979; Steve Hall, "Student drinking revealed in college study," The Daily Athenaeum, November 29, 1979; Jennifer Knox, "Students cite best methods of managing college stress," The Summer Athenaeum, June 29, 1988, 25. 
that Sunnyside and WVU students, both carrying controversial identities, could not be broadly categorized.

Although parties peaked in the fall and spring, students who stayed in Morgantown throughout the summer enjoyed freedoms. One student wrote that Morgantown "breathes a sigh of relief and settles down for a quiet summer." ${ }^{, 71}$ Sunnyside also had a vacation from student crowds, with taverns and other businesses effectively shutting down in the summer. "Sunnyside is dead..." one student testified. "It's like they roll up the sidewalks and don't let them back down until August." ${ }^{, 72}$ As more businesses trended toward summer hours in the 1980s, Sunnyside attracted an older and more easygoing crowd. Although students felt camaraderie among the crowds during the school year, the absence of crowds forged stronger bonds among friends. Morgantown life felt easier, as students could find parking, walk or bicycle through town, and enjoy game nights, dart leagues, food samplings, and music in the evenings. The abundance of outdoor activities, including hiking, kayaking, and camping, could serve as vacations for students who did not voluntarily stay in the summer. ${ }^{73}$ Sunnyside, therefore, offered students year-round recreation.

Although students felt free to do as they pleased in Sunnyside, tradition obligated certain activities and behaviors. These traditions forged a sense of community with a shared history that, in a transient neighborhood like Sunnyside, succeeding classes of students could engage. Their persistence into the twenty-first century reflects the social and culture importance of student traditions, even when these traditions are risky.

${ }^{71}$ Julie Watkins, “Morgantown: Is there life after finals?” The Daily Athenaeum, May 2, 1985, 5.

72 Ibid.

${ }^{73}$ Trish Liberto, "Summer: a time to enjoy less harried campus life," The Summer Athenaeum, May 29, 1980, 1, 4; Trish Prospero, "Sunnyside cools down hot and thirsty students," The Summer Athenaeum, June 7, 1984, 9-10; David Wilkinson, "Local night havens prosper during summer," The Summer Athenaeum, May 23, 1985, 1, 6; Julie Watkins, “Morgantown: Is there life after finals?” The Daily Athenaeum, May 2, 1985, 5. 
“Tradition means a lot - maybe everything to a college campus," wrote student Jeff Ritchie, capturing a sentiment that Sunnyside's traditions reflect. In a full-page article of The Summer Athenaeum, Ritchie mused about Sunnyside, calling it "a state of mind - and a twisted one at that." He noted images imprinted in his memory: foaming beers, blaring music like "Baba O'Reilly" by The Who, and old houses packed with young kids discussing literature through "a Miller's induced fog." ${ }^{74}$ Such rituals were integral to how students conceptualized the party subculture in Sunnyside. ${ }^{75}$

When the drinking age rose to 21 in 1986, students like Ritchie wondered how Sunnyside would change. Some students under 21 felt more than disenfranchised; they felt cut off from a WVU tradition. ${ }^{76}$ One article in the Monticola summarized the significance of these traditions: "When someone asks, 'How is school?,' the student replies, 'The parties are great; Sunnyside is a lot of fun; dancing at the bars is fantastic.' No mention of academics.. ${ }^{, 77}$ While the WVU community would use the University's respectable academics to deflect accusations as a party school, some students found the University's social extracurricular activities more enticing.

The Daily Athenaeum offered students a less filtered introduction to the University through its "unofficial" student guides. These guides attempted to inform prospective students of "the language and habits" of WVU culture. ${ }^{78}$ One unofficial guide of WVU slang defined Sunnyside as "the-place-to-be after a long week or a GREAT football game." "Weekends," in this context, began on Thursday night, while "T.G.I.F.-in," (pronounced "jiffin”) were happy

\footnotetext{
${ }_{75}^{74}$ Jeff Ritchie, "Will Sunnyside Ever Be the Same?" The Summer Athenaeum, July 9, 1986, 5.

${ }^{75}$ Weiss, Party School, 57-64; Wechler and Weuthrich, Dying to Drink, 4-19; Tan, "Through the Drinking Glass,"121.

${ }^{77}$ Jeff Ritchie, "Will Sunnyside Ever Be the Same?" The Summer Athenaeum, July 9, 1986, 5.

${ }^{77}$ Karen Garvin, “Activity Thrives After Hours," Monticola, 1983, 16-17. 6, 1984, 6 .

${ }^{78}$ Crystal Dempsey, "What they didn't tell you...the unofficial student guide," The Daily Athenaeum, July
} 
hours that began on Fridays at noon. ${ }^{79}$ Upperclassmen set a precedent for new students to explore Sunnyside's party scene. "A new student may not know where his classes are," one article read, "but he can find all the bars in Sunnyside." 80

Some of WVU's most important traditions involved sports. Throughout the twentieth century, Mountaineer fans descended on Morgantown during home football games, traveling on West Virginia's improved roads and new interstates to take advantage of a new culture of tourism and leisure. "The football weekend" transformed Morgantown, a city in which the permanent resident population could fit comfortably in the football stadium. Even as WVU's enrollment and facilities expanded into the mid-twentieth century, the University still clamored to catch up with larger schools. One area in which WVU became outpaced was in its sports facilities. By the 1970s, college athletics nationally had grown more professional and more expensive, though the challenges that accompanied such a cultural change did not outweigh the incentives for community development. ${ }^{81}$ To bring itself up to competitive standards, WVU closed the old Mountaineer Field, situated between the Downtown campus and Sunnyside, and opened the new Mountaineer Field in 1980 on the Evansdale campus. The closing of the old Mountaineer Field signaled a major change not only in WVU's approach to athletics, but in the culture of Sunnyside.

Mountaineer Field's physical presence was a touchstone of the Sunnyside community, as were the traditions that relied on its concentration of spirited WVU fans. ${ }^{82}$ The last game at Old Mountaineer Field was played in November 1979. Police took "extra precautions," with up to

\footnotetext{
$6,1984,6$.

${ }^{79}$ Crystal Dempsey, "What they didn't tell you...the unofficial student guide," The Daily Athenaeum, July

${ }^{80}$ Karen Garvin, “Activity Thrives After Hours,” Monticola, 1983, 16-17.

${ }^{81}$ Barnett, Hillside Fields, xxiii-xxiv, 171-172.; Gumprecht, The American College Town, 227-230; Timothy Jon Curry, Kent Schwirian, and Rachael A. Woldoff, High Stakes: Big Time Sports and Downtown Redevelopment (Columbus: The Ohio State University Press, 2004), 15-16.

82 Brad Dilling, "Sunnyside affected by changes," The Summer Athenaeum, May 28, 1986, 20.
} 
three-fourths of University police on duty that night, patrolling the stadium and managing crowds around it. ${ }^{83}$ In Sunnyside, residents wondered what the closure and demolition of Old Mountaineer Field would mean for their way of life. While business patronage and foot traffic declined, students maintained Sunnyside as part of pregame and postgame traditions even with the new football stadium on the Evansdale campus. Fueled by the thrill of competition, these rituals often involved noise complaints, throwing of bottles and cans, blocking traffic, profane and inappropriate language, littering, trespassing, and property damage. ${ }^{84}$ Before games took place, fans engaged in tailgating, which one student called the "appetizer before the game.",85 Afterward, students devised "the quickest route to Sunnyside" and considered victorious celebrations "integral aspects of following Mountaineer football." 86

Block parties and bonfires are perhaps Sunnyside's most infamous traditions. Developing sometime in the 1970s, these festivities became traditions to kick off a new school year, to blow off steam after finals, or to celebrate a victory against a football rival. Together, the block parties and bonfires epitomized the Sunnyside problem. Unlike parties in individual houses or bars, block parties occurred on a large scale, in a more public space, and could be defined by time as a tradition. Grant Avenue became the epicenter of Sunnyside block parties, gathering hundreds to thousands of students as well as dozens of police offers. Students, therefore, were not the only members of the WVU community engaging in this tradition. ${ }^{87}$ As the tradition entrenched within

\footnotetext{
${ }^{83}$ Toni Locy, “Campus security 'beefed up' for last home game at stadium,” The Daily Athenaeum, November 8, 1979, 1 .

${ }^{84}$ David Singleton, "Petition to close taverns in Sunnyside area circulated," The Daily Athenaeum, November 1, 1977, 1; Brad Dilling, "Sunnyside affected by changes," The Summer Athenaeum, May 28, 1986, 20; Weiss, Party School, 57-64.

85 Paul Burnett, "Tailgates and Togas: The University Party Scene," Monticola (1986), 22-23.

86 “Tradition changes," The Daily Athenaeum, September 4, 1985, 6.

${ }^{87}$ Brad Dilling, "Sunnyside affected by changes," The Summer Athenaeum, May 28, 1986, 20; Ken Ward Jr., "Police, students call block party a success," The Daily Athenaeum, August 24, 1988, 1; "Cooperation: partiers cause few problems," The Daily Athenaeum, August 24, 1988; Weiss, Party School, 62-63; Lewis, Aspiring to Greatness, 487-489.
} 
student culture at WVU, the broader community acknowledged that if they could not stop the parties from taking place, they could instead try to understand them. In the 1980s, the Dean of Student Life, Herman Moses, admitted to observing Grant Avenue block parties because he had “an interest in what was going on there." 88

Bonfires were a distinct focal point of Sunnyside block parties. The image of partiers encircling a bonfire remained long after the night ended and the crowds went home, in local memory and in the pages of The Daily Athenaeum and WVU yearbook, Monticola. The fires reflected Sunnyside's physical image as a dilapidated student slum, filled with enough trash and disposable furniture for students to build robust blazes in the street. Furthermore, the students building these fires engaged in risk-taking that Sunnyside and its party subculture justified. The fires, often built as a climax to the party, risked student safety and adherence to the law. However, students minimized these risks when considering the outcome: a good time and participation in a WVU tradition. ${ }^{89}$

Some students worked to create new Sunnyside traditions. They organized cleanups of Sunnyside to address the aftermath of parties. In April 1978, the Students for Essential Environmental Development (SEED) organized an Earth Day Cleanup in Sunnyside, along with the Downtown campus, to collect "unsightly trash and debris" that were the results of "neglect and disrespect." 90 The Student Administration endorsed this event, calling SEED's efforts "refreshing and inspiring." ${ }^{91}$ Hundreds of volunteers turned up for the event, which was coordinated with the University and city. They also encouraged tenants in Sunnyside to care for

\footnotetext{
${ }^{88}$ Ken Ward Jr., "Police, students call block party a success," The Daily Athenaeum, August 24, 1988,1

${ }^{89}$ Brad Dilling, "Sunnyside affected by changes," The Summer Athenaeum, May 28, 1986, 20; Ken Ward Jr., "Police, students call block party a success," The Daily Athenaeum, August 24, 1988, 1; Weiss, Party School, 62-63, 123-127; Lewis, Aspiring to Greatness, 487-489.

90 Mike Fulton, "Reviving Earth Day," The Daily Athenaeum, April 11, 1978, 8.

${ }^{91}$ David Hendrickson and Michael Nogay, "Earth Day," The Daily Athenaeum, April 20, 1978.
} 
their own properties. ${ }^{92}$ The Earth Day cleanups, which occurred for years after, reflect a different form of the Sunnyside spirit, one based on stewardship of the landscape and community.

On the other hand, The Daily Athenaeum editor Rick Ridgway satirized the Earth Day cleanup in his editorial, "Project Bonfire: Good job, students." This demonstrates that while the Earth Day cleanup was appreciated, some students found Sunnyside's daily traditions of drinking and partying more overpowering. Ridgway created fictional students whose "nagging hangovers" prevented them from helping with the cleanup. Instead, these students invented "Earthy Night," in which they aimed to "fix up Sunnyside and have a good time" simultaneously. Their cleanup did not involve trash bags and recycling, but lighting anything they saw on fire. "Trees, sofas, dressers, beer bottles, and other objects were sacrificed in the inferno," Ridgway wrote, echoing Sunnyside's block party bonfires. ${ }^{93}$ Both the real and fictitious Earth Day events engaged students in considering behavior within the context of Sunnyside.

The last component of Sunnyside spirit is romanticism of student activities. Through immediate expressions of freedom and longstanding traditions, students used romanticism to keep the good times going. On the surface, their musings focus on these good times. With a closer look, however, a "sense of place" emerges. In a time when American landscapes increasingly sprawled with shopping malls, big box stores, and bland office buildings, Sunnyside offered students mythic authenticity that could only exist within the college years. ${ }^{94}$

Student romanticism of Sunnyside comes across in their writings. They used distinct language that evoked wonder and awe. Student Jeff Ritchie wrote, "Take your Paris or London -

\footnotetext{
92 Sue Scancella, "Task force hopes to beautify Sunnyside, main campus area," The Daily Athenaeum, April 21, 1979; Sam Greco, "SEED sends thanks," The Daily Athenaeum, April 28, 1979, 12.

${ }_{93}$ Rick Ridgway, "Project Bonfire: Good job, students," The Daily Athenaeum, April 24, 1979, 14.

${ }^{94}$ Isenberg, Downtown America, 255-257, 315.
} 
if they're yours to take - give me Sunnyside on a Saturday night every time." ${ }^{95}$ Similarly, an article in the Monticola, WVU's yearbook, called Sunnyside “Morgantown's answer to the Las Vegas Strip."96 Such exaggerated language demonstrates how students felt about the neighborhood. Sunnyside was as a student destination, especially for a small city like Morgantown. Whereas students complained about Morgantown, one giving it the degrading name of "Morganhole," Sunnyside was an oasis in the city's exhausting expanse of traffic and hills. $^{97}$

Some students saw troubling and even illegal behaviors through rose-colored glasses. Their romanticism of certain behaviors made them more willing to dismiss these activities, especially if they were part of a greater tradition. An article in the Monticola recalled the parties in Sunnyside following a 1982 Oklahoma Sooners game, noting "intuition" that drew students into Sunnyside. The article's language acknowledged intervention by local authorities, but emphasized student spirit instead: "Even the police and firemen could not damper the spirits of the stout-hearted fans. After the first bonfire was extinguished, it did not take long for two more to ignite. Although fire hazards were a problem, the type of celebration was hard to compare with." 98 Their spirits, much like the fires set on the street, could not be easily extinguished. Students like Daniel Corey, a second-year law student, acknowledged Sunnyside’s “deceptive lure" while continuing to romanticize its "brilliance and glory."99

Romanticism in Sunnyside was closely tied to memory, as shown by the reminiscent tone of articles in the Monticola and The Daily Athenaeum. "I suppose that regardless of whether this

\footnotetext{
95 Jeff Ritchie, “Will Sunnyside Ever Be the Same?” The Summer Athenaeum, July 9, 1986, 5.

96 “"That's Entertainment," Monticola (1979) 92.

97 Drew Nettles, "Getting those nasty, old ID card blues," The Daily Athenaeum, September 4, $1985 ; 6$.

98 Terri Weimer, “Any Occasion Makes Way for a Celebration,” Monticola (1983) 42-43.

99 Daniel Corey, "Your parents were right about college," The Daily Athenaeum, August 29, $1985,6$.
} 
event will be looked at as dangerous or stupid, it will be remembered as a fun and somewhat more exciting Saturday night in Sunnyside," student Jeff LiButti wrote. "It brought students, friends and strangers alike, together for an extra hour or two...also, for those leaving in a year, it will be a perfect way to remember the University and the turbulent strip of bars known as Sunnyside."

The Sunnyside spirit carried nuanced meanings to students of the 1970s and 1980s. In a time when the University grew in prestige, the Sunnyside spirit reflects a larger narrative of the WVU community's concern for its image. Still, some argued that the Sunnyside spirit did not accurately reflect the progress made in Sunnyside. "There is a new spirit of Sunnyside and it grows each day," wrote Joseph Gallen, the owner of a Subway at the corner of University Avenue and Campus Drive, who felt that The Daily Athenaeum did not see progress in Sunnyside as "newsworthy."101 From a student perspective, Nancy Martin called the new spirit she witnessed the "Mountaineer spirit," which encompassed the academic achievements and comfortable environment of WVU. "This is the image that should be emphasized - the departmental publications, the faculty being recognized in their fields, the various honors received by students, keeping pace with technological advancement, and so much more."102 Sunnyside's image as a cultural landscape emerges through studies of student activities, identities, and perceptions. Their expressions of freedom, tradition, and romanticism capture their sense of place.

\footnotetext{
${ }^{100}$ Jeff LiButti, “Letters: On Sunnyside," The Daily Athenaeum, April 26, 1979, 12.

101 Joseph R. Gallen, "Letter to the Editor," The Summer Athenaeum, July 19, 1984, 9-11.

102 Nancy J. Martin, "Response to Sunnyside," The Summer Athenaeum, July 16, 1986, 5.
} 


\section{The Sunnyside Solution?}

"Oh Sunnyside! Ye infamous bastion of beer-drinking and hell-raising, whatever shall we do with your rowdy masses and littered streets? Is there really a solution at all?" ${ }^{103}$ In his column, student writer for The Daily Athenaeum, David Singleton, wondered about solutions. This is perhaps a Sunnyside tradition in its own right. Sunnyside's history as a student neighborhood is nuanced and complex. Today, various groups are involved in finding these solutions. Still, it is worth looking back and critically analyzing how students and the WVU community at large have conceptualized Sunnyside.

By the 1990s, both town and gown communities explored new avenues for addressing problems in Sunnyside. At this point, partying had escalated to new levels. The Grant Avenue block party became an annual tradition, drawing students from WVU, as well as Marshall University and schools in Pittsburgh. On August 22, 1994, around 10,000 student flooded Grant Avenue. ${ }^{104}$ The fun turned to violence as "beer bottles soared, fists flew, and two University students were shot." The incident unleashed questions not only about security, but also student freedoms, traditions, and their romanticism of college experiences. Whereas some students continued call the party "awesome," others felt stunned, embarrassed, and disgusted. One student recalled a friend who traveled to Morgantown for the party saying he "wanted to leave and never come back." ${ }^{\prime 105}$ The party not only left social and cultural scars, but a mess that residents had to clean up the following day. One student tenant, who had tried and failed to keep her house party limited to close friends, expressed frustration that her yard had turned to "mud and beer

${ }^{103}$ David Singleton, "Sunnyside's solution," The Daily Athenaeum, September 2, 1977, 8.

${ }^{104}$ Stacy Kennell, "Unstoppable Block Party chugs on," The Daily Athenaeum, August 22, 1994, 1; Stacy Kennell, "Block bash bangs," The Daily Athenaeum, August 23, 1994, 1, 8;

${ }^{105}$ Stacy Kennell, "Grant party goes bad," The Daily Athenaeum, August 24, 1994, 1, 12. 
puddles," dirt turned the floors "black," and the carpet "squeak[ed] from all the beer." "106 Both town and gown communities agreed that responsibility fell on everyone's shoulders, though WVU, as one of the state's largest and most powerful institutions, took the brunt of the criticism. Still, no one knew how, or if, the block parties could be stopped. ${ }^{107}$

Although partying at WVU continues to this day, the 1990s and 2000s were an era of seeking solutions to the Sunnyside problem. First, the WVU community sought more controllable alternatives to Sunnyside's block parties. WVU President David Hardesty, working alongside student groups, was instrumental in addressing the party school image by redirecting student enthusiasms and marketing the University in a positive way. Since 1995, WVU has hosted FallFest, a festival of music, food, and beer located on campus. FallFest was held at the MountainLair until 2016, when it was moved to the Evansdale campus to provide more space for crowds. To complement this annual event, the University instituted WVUp All Night in 1998, which opens the MountainLair late into the night Thursdays to Saturdays for students to enjoy free food, games, crafts, and performances. ${ }^{108}$

Student Administration became involved in controlling parties and combating crimes such as sexual assault. They suggested non-students avoid parties, encouraged socializing in backyards rather than front yards or streets, informed hosts about the legal ramifications of alcohol abuse or underage drinking, and organized cleanup events. Some college towns have instituted "Animal House laws" to curb and control student partying by evicting students or requiring permits for large parties. In 1998, Morgantown City Council instituted their own form

\footnotetext{
${ }^{106}$ Stacy Kennell, "Residents clean the morning after," The Daily Athenaeum, August 24, 1994, 1, 12.

${ }^{107}$ Gail D. Taylor and Monte Maxwell, "Chief blames WVU," The Dominion Post, "August 24, 1994, 1; Stacy Kennell, "City recovering from Grant party," The Daily Athenaeum, August 25, 1994, 1, 8.

${ }^{108}$ Lewis, Aspiring to Greatness, 482-491; Erin Drummond, "FallFest 2016," The Daily Athenaeum, August 17, 2016, http://www.thedaonline.com/arts_and_entertainment/article_541ee8ec-6439-11e6-88b70b081a68446f.html; Erin Drummond, "WVUp provides alternate activities," The Daily Athenaeum, August 18, 2016, http://www.thedaonline.com/arts_and_entertainment/article_5d6eb9e0-65ab-11e6-b75e-1ff6842cc960.html
} 
of an Animal House law by banning the placement of indoor furniture in outdoor spaces. The 1990s saw a spike in the number of street fires, rising from no more than 20 per year in the early 1990 s to more than 100 per year in the late 1990 s, peaking at 255 fires in 2003 . This law sought to lessen the amount of kindling available for street bonfires. ${ }^{109}$

Lastly, revitalization became a significance force for change in Sunnyside. Nationally, revitalization flourished in the second half of the twentieth century, especially as historic preservationists developed new strategies to prevent the destructive urban renewal of earlier decades. Morgantown first took advantage of grant programs to create more parking, enhance walkways, install lighting, and pave alleys in Sunnyside. Then, it engaged in revitalization trends that encouraged downtowns repurpose old buildings and instill a sense of history within their projects. The Seneca Center is the most quintessential example of this form of revitalization in Sunnyside. A former glass factory, the Seneca Center retains its historical charm while housing shops and small businesses. ${ }^{110}$

Other revitalization projects have kept solving the Sunnyside problem, in its physical and social forms, at the forefront of their missions. The Campus Neighborhoods Revitalization Corporation, also known as Sunnyside Up, spearheads "urban land use plans designed to eliminate blight, improve conditions, and prevent future deterioration” in Sunnyside. Through TIF Projects and partnerships with the city of Morgantown and WVU, Sunnyside Up uses new infrastructure and street reconfigurations to address practical issues, such as housing, amenities,

\footnotetext{
${ }^{109}$ Weiss, Party School, 10; Lewis, Aspiring to Greatness, 487-489; Bryan Bumgardner, "Couch fires really a true WVU tradition," The Daily Athenaeum, December 5, 2012, http://www.thedaonline.com/article_5ec897ac-0002-52ca-846f-cc008f4a428b.html; Ken Ward Jr., "Sutton trying to keep party on tap," The Summer Athenaeum, June 27, 1990, 2; "Sutton's idea is smart," The Summer Athenaeum, June 6, 1990.

${ }^{110}$ Isenberg, Downtown America, 255-256, 304; John Donaldson, “City seeks money for Sunnyside,” The Summer Athenaeum, May 24, 1990.
} 
traffic, and parking, that drive up property value. ${ }^{111}$ These efforts emerge from a different interpretation of local history, one that acknowledges the original infrastructure in Sunnyside was built to hundred-year-old standards and recent issues of "uncontrolled activities and no maintenance. $" 112$

Today, Sunnyside continues to be the landscape of the nation's \#1 party school. Patterns of condemnation and acceptance of the party school label demonstrate the WVU community's concern for student behavior and University image. They provide historical context for contemporary issues of student drinking and the "Sunnyside spirit," a term that while not in use today, still reflects general patterns of student behavior. Studies of the 1970s and 1980s, formative decades of Sunnyside's mythology, informs contemporary studies of the party school image and activities. Today, students who defend this lifestyle claim these activities are normal and occur in private spheres, while intervention with the police is considered ineffective. A historic look at partying in Sunnyside demonstrates the normalizing of both the activities in Sunnyside and the University's image. ${ }^{113}$

The party school image remains in the public eye, as WVU parties top lists in popular magazines and circulate on social media. More recent parties shape how students are engaging in Sunnyside's cultural landscape and grappling with revitalization efforts. In 2012, Sunnyside was the setting of a Saint Patrick's Day party, gathering 500 to 600 students who set fires, guzzled alcohol, and prompted hundreds of noise complaints. When the ruckus appeared on "I'm Schmacked," a YouTube documentary that currently has over 165,000 views, WVU seemed to

${ }^{111}$ Campus Neighborhoods Revitalization Corporation, From Mutt's Place to University Place, 17-22.

112 Emily Leslie, "What happened to Sunnyside? Where did it all go?" The Daily Athenaeum, May 12, 2015, http://www.thedaonline.com/news/article_fbefe0fe-f382-11e4-b08d-0fd201495fde.html.

${ }^{113}$ Weiss, Party School, 115, 123-126. 
live up to its reputation. ${ }^{114}$ "We thought 'Number One Party School' was cool at the time," one student recalled. ${ }^{115}$ As the tradition continued, it challenged town-gown relationships. To manage crowds, the University and city worked together on the Shamrock Safety Squad, the Mon County Prevention Coalition, WVU Collegiate Recovery Program and the Safe Communities Initiative. Local police hoped for "true community policing," by encouraging students to report crimes on LiveSafe, a smartphone app. ${ }^{116}$ Sunnyside's recent changes, however, contextualized their memory of these parties. "We had all of our best times in places that aren't really there anymore," one recent graduate said. ${ }^{117}$

Other members of the WVU community have found different outlets, ranging from academic research to online communities, for exploring the Sunnyside problem. The WVU History Department has documented buildings, landmarks, and groups of people throughout Sunnyside's history, and shared research through a variety of public history projects. Student housing has been the subject of student theses, such as journalism graduate student Leann Ray's 2012 blog, Inspecting Sunnyside, and sociology Frank Harrison Anne’s 2013 MA thesis, "Normalization of Neighborhood Disorder in a College Town," which examines the South Park neighborhood but informs discussions of Sunnyside as a student neighborhood. Lastly, an

${ }^{114}$ Lydia Nuzum, "City condemns illegal student behavior," The Daily Athenaeum, March 21, 2012, accessed March 26, 2017, http://www.thedaonline.com/article_a6583bb8-4c36-58e6-9359-765c77020a35.html; Adrianne Uphold, "St. Patrick's Day sends WVU through culture changes," The Daily Athenaeum, March 17. 2017, accessed March 26, 2017, http://www.thedaonline.com/news/article_32ceb3f0-0acb-11e7-996c-2f0a9232c9dd.html; ImSchmacked, "I'm Shmacked The Movie: WVU St. Patricks Day ft. Huey Mack," YouTube, accessed March 26, 2017, https://www.youtube.com/watch?v=SUCp4EOJej8

${ }_{115}$ Adrianne Uphold, "St. Patrick's Day sends WVU through culture changes," The Daily Athenaeum, March 17. 2017, accessed March 26, 2017, http://www.thedaonline.com/news/article_32ceb3f0-0acb-11e7-996c2f0a9232c9dd.html

${ }^{116}$ Amy Pratt, "Morgantown and WVU collaborate on St. Paddy's," The Daily Athenaeum, March 17, 2017, accessed March 26, 2017, http://www.thedaonline.com/news/article_3c27c44c-0aca-11e7-a858$7 \mathrm{f} 8 \mathrm{c} 24 \mathrm{~d} 3 \mathrm{~d} 177 . \mathrm{html}$

${ }^{117}$ Adrianne Uphold, "St. Patrick's Day sends WVU through culture changes," The Daily Athenaeum, March 17. 2017, accessed March 26, 2017, http://www.thedaonline.com/news/article_32ceb3f0-0acb-11e7-996c2f0a9232c9dd.html 
enthusiastic group of alumni share stories on the Remembering Sunnyside WVU Facebook page, which currently has more than 6,500 followers. ${ }^{118}$ Whether from an academic or personal perspective, public interest shows Sunnyside's historic and contemporary significance.

Through their freedom, traditions, and romanticized imagery, students conveyed Sunnyside as a central part of the WVU student experience. They passed down a mythology that continues today. Although discussions of the Sunnyside problem continue, students are still encouraged to see Sunnyside as part of their student experience. A 2015 "bucket list" published by The Daily Athenaeum encouraged students to "take a drive down Grant Avenue and reminisce on the good ol' days of Sunnyside." ${ }^{119}$ Students like Hannah Chenoweth, class of 2015, wrote with overpowering nostalgia in The Daily Athenaeum about her time at WVU. She emphasized "the rare and unbreakable kinship that each and every Mountaineer shares," even while she and her friends condemned the "shenanigans" of the "I'm Schmacked" video. Even with her graduation just a few weeks away, Chenoweth was already musing about missing Sunnyside, comparing it to a faraway destination. "Sunnyside was a whole different world, one in which we ventured with a squad of ten other kids from our dorms every weekend," she wrote. Although traditions continued to be passed down, Chenoweth acknowledged the developments in Sunnyside and the effects it would have on future students, that Sunnyside's traditions were changing. "Our class experienced a different atmosphere in Morgantown in 2011-2012 many

118 Mackenzie Mays, "Blog helps students make informed housing decisions," The Daily Athenaeum, February 1, 2012, http://www.thedaonline.com/article_7772e36e-bb2d-5cce-bd1f-c3c8b4147dbc.html; Leann Ray, "Inspecting Sunnyside," accessed April 2, 2017, https://inspectingsunnyside.wordpress.com; Frank Harrison Annie, "Normalization of Neighborhood Disorder in a College Town: Now Students Making Sense of their Community." MA Thesis (West Virginia University. Morgantown, 2013).

119 Ally Litten, "Motown bucket list: Things to do before you graduate," The Daily Athenaeum, April 30, 2015, http://www.thedaonline.com/arts_and_entertainment/article_ee1b0d0c-efa7-11e4-b93b-4bc2ac1eedfd.html 
freshmen will never be able to understand," she asserted. ${ }^{120}$ Such musings are a reminder that Sunnyside is constantly reinterpreted by its people.

As students graduate, romanticism turns to nostalgia. Like romanticism, studying nostalgia can shed light on how people conceptualize their experiences and where these experiences took place. Nostalgia, however, often involves a perception that the passage of time has eroded these experiences, causing a yearning for "what was." For traditional undergraduate students, whose college years are bound by a distinct framework of time and place, the college experience is relatively fleeting. For many WVU students, Sunnyside was a gateway into this college experience. As alumni, they reminisce with old friends in online communities like the Remembering Sunnyside WVU Facebook page, a digital representation of Sunnyside’s enduring culture. ${ }^{121}$ The nostalgic connections students form with their landscapes show how they create meanings and preserve memories of a formative time in their lives.

${ }^{120}$ Hannah Chenoweth, "To the class of 2015: Remembering Morgantown," The Daily Athenaeum, April 26, 2015, http://www.thedaonline.com/opinion/article_458b421a-ec78-11e4-b46c-97e1b163f43b.html.

${ }^{121}$ Sergio Davalos, et al. "The good old days': An Examination of Nostalgia in Facebook Posts." International Journal Of Human-Computer Studies. Vol. 83 (November 2015): 84; Barbara Shircliffe, “'We Got the Best of That World': A Case for the Study of Nostalgia in the Oral History of School Segregation," The Oral History Review, Vol. 28, No. 2 (Summer-Autumn 2001): 61-62; Shaw and Chase, The Imagined Past, 1-4. 


\section{CONCLUSION}

Sunnyside is many students' "home sweet away-from-home" while living in Morgantown or seeking the college experience at WVU. "Home" is a powerful concept for WVU students, who foster Mountaineer pride, don spirit wear featuring the state of West Virginia, and passionately sing John Denver's “Country Roads." In The American College Town, geographer Blake Gumprecht discusses the college campus as "representative of a larger purpose - it is a park, a cultural center, a meeting place, and a symbol.." In Morgantown, Sunnyside is also representative of a larger purpose, one created by its residents, its visitors, and its observers.

As one of the "mundane, ordinary, and constantly reused" cultural landscapes that Dolores Hayden describes, Sunnyside's meanings and significance can be better understood through history. ${ }^{3}$ The cultural landscape approach appreciates Sunnyside for all its complexities, allowing memory, transience, and labels to become part of its history. At the same time, cultural landscapes challenge historians to grapple with questions of preservation and interpretation. As Sunnyside's physical landscape changes with every demolition and construction, historians face not only the ticking clock, but also time-sensitive questions about how to tell stories and the broader implications of these stories being told. This is how research conducted by the WVU History Department carries multiple meanings: it creates new documentary records within a broader context of change.

Looking at Sunnyside from a minute yet holistic perspective diversifies traditional narratives of the glass town and college town. Since the 1890s, Sunnyside has housed a

\footnotetext{
${ }^{1}$ Charley Cumpston, "Housing Woes for Sale; Rickety Rooms Available," The Daily Athenaeum, September 16, 1965, 1.

${ }^{2}$ Gumprecht, The American College Town, 70.

${ }^{3}$ Hayden, The Power of Place, 227.
} 
predominantly transient population, heading to work in the factories and to attend the University. Still, it was also home to more stable Morgantown residents who found stable work, raised families, and deeded their homes to their children later in life. This story arc of Sunnyside's 120 years demonstrates the diversity of changes that have occurred. The demolition of small frame houses and construction of high-rise apartments reflects a new form of studentification of Sunnyside, as different groups of students replace one another. It is a reminder that change, varying in type and intensity, is part of Sunnyside's past as it is in the present. It reaffirms the historian's role in preservation of physical structures or the stories of those that surrounded and occupied them.

As a student neighborhood, Sunnyside became caught in debates over student freedoms, access to off-campus housing, and housing quality. The recent past informs modern debates over similar manifestations of these issues. WVU student responses to in loco parentis reflects national trends in the 1960s. Examining these responses provides context for student demands for off-campus housing options. In off-campus housing, students expressed feelings of freedom and self-ownership that they felt affirmed their young adulthood. Formal activism in the late 1960s and early 1970s reflect organized demands to do away with in loco parentis policies and provide students with fair treatment and high-quality housing. Such activities continued into 1979, when student voters helped pass a code in Morgantown setting minimum housing standards.

The Sunnyside problem and Sunnyside spirit represent two interpretations of Sunnyside's personality, reflecting the long and contentious history of West Virginia stereotypes. As administrators and city officials posed solutions to the Sunnyside problem, such as new university programs, policies, and city ordinances, students engaged in these questions, too, 
embracing or rejecting the "\#1 party school" label or characterizations of "Sunnyside spirit." The success of these initiatives, including conversation itself, is much like the Sunnyside problem: highly open to interpretation. Student contributions reflects the individuality of student perspectives, but allows for a diverse image of the WVU student body. They also demonstrate how modern debates over Sunnyside's image are part of a larger history.

Through the stories of students, as well as others who have called Sunnyside home, an important theme emerges: that the neighborhood's lifeblood is its people, who reimagine its purpose through their ways of life, either by choice or necessity. It is also shaped by those who do not live there, including WVU administrators, city officials, landlords, and revitalization groups who have their own ideas for Sunnyside. As WVU continues to exert more influence over Sunnyside, it raises important questions about the level of such influence and whether students are represented in these conversations. It also raises questions with less tangible answers about how a University and surrounding town grapple with history. Because universities are constantly looking forward, questions of historic preservation may seem contradictory. And yet, universities and colleges rely on their age to establish credibility and regularly invoke the past to form their identities. No other university is recognized by its musket-wielding Mountaineer or the grandeur of Woodburn Hall.

Future research can continue teasing out the complexities of student-university and towngown relationships. Studies could more closely examine student relationships with landlords, police, and the University, and add more nuance by exploring the dynamics of gender, race, age, and other student demographics. Other studies could focus on the 1990s and 2000s, in which student parties peaked and revitalization efforts commenced. Perhaps most importantly, future research can engage community members through oral histories, surveys, and projects. As John 
R. Thelin argues, the history of higher education should be guided by both the "official" records of a university, like the paperwork piled in president's offices, as well as the "unofficial" memories passed between students or reminiscing alumni at the local pub. Such accounts, as Thelin wrote, have "an enduring, powerful impact on how Americans think about colleges as historic, special places."4

As revitalization efforts continue across the country, public historians and preservationists look for ways to "shift the paradigm from a default assumption of demolition to one of building reuse." Contemporary revitalization in Sunnyside serves as context for additional studies on the application of historical research, historic preservation, and cultural landscape. Historic preservationists argue that "used with purpose and imagination, cultural landscape can, and should, be an essential underpinning of preservation, opening a whole new chapter on our understanding of, and respect for, the world around us." ${ }^{6}$ Historic preservation, from their perspective, is not the antithesis of sustainable development. Rather, they argue that historic preservation is "the ultimate in recycling," capable of saving resources, money, and energy as well as the integrity of manmade structures and cultural landscape. ${ }^{7}$

Public historians have used the cultural landscape approach to refresh outdated narratives and engage with the public in grassroots initiatives, especially in neighborhoods, where landscapes and residents are traditionally overlooked in monolithic histories. ${ }^{8}$ Sunnyside presents

${ }^{4}$ Thelin, A History of American Higher Education, xviii.

${ }^{5}$ Will Cook and Tom Mayes, "Shifting the Paradigm from Demolition to Reuse: New Tools," Preservation Leadership Forum, National Trust for Historic Preservation, February 16, 2017, accessed March 29, 2017, http://forum.savingplaces.org/blogs/special-contributor/2017/02/16/shifting-the-paradigm-from-demolition-to-reusenew-tools.

${ }^{6}$ Longstreth, Cultural Landscapes, 15.

${ }^{7}$ Donovan Rypkema, "Sustainability and Historic Preservation," Economic Benefits of Preservation, Preservation Action Council of San Jose, March 10, 2007, accessed March 29, 2017. http://www.preservation.org/rypkema.htm

${ }^{8}$ Andrew Hurley, "Narrating the Urban Waterfront: The Role of Public History in Community Revitalization," The Public Historian, Vol 28, No. 4 (Fall 2006): 19-20, 50. 
several public history opportunities, including exhibits, waysides, walking tours, digital history, and oral history projects. Because public interest in Sunnyside remains strong, public historians can engage audiences in shared authority. Through public history, neighborhoods like Sunnyside can not only tell diverse stories of identity and interaction, but invite community members to tell the stories themselves. Furthermore, public historians may lend their voices to conversations on revitalization and facilitate discussion on the purpose and meaning of history in an actively transforming place.

It is difficult to bring a subject's narrative to a conclusion when, in reality, its end is unwritten. Every day Sunnyside is changing, its physical composition reshaped by revitalization projects and its population shifting each iteration of transient residents. One can drive down Sunnyside's streets and find swaths of century-old buildings leveled, making way for new highrises and empty lots awaiting their fate. The historian can play a unique role amid these changes. Through documentation and interpretation, historians preserve Sunnyside. This study leaves much to be discussed. That is not only the nature of historical studies, but integral to this study in particular. People throughout time and place have viewed Sunnyside through difference lenses, shaping their perspectives and the records they leave behind. Sunnyside invites future researchers to enter a rich past through a momentous present.

Sunnyside continues forward. Social activities, cultural expressions, and physical environments are bound by individual and collective memories that, together, instill meaning. When change interrupts these memories, people find various ways to respond, through new memories, nostalgic reminiscing, and action. These undulant meanings and memories reflect the power of cultural landscapes and the sense of place. ${ }^{9}$

\footnotetext{
${ }^{9}$ Hayden, The Power of Place, 9-11.
} 


\section{BIBLIOGRAPHY}

\section{Government Documents}

West Virginia. Monongalia County, Deed Books. Office of the Recorder of Deeds, City of Morgantown.

West Virginia. Monongalia County. U.S. Census. http://ancestrylibrary.com.

\section{Newspapers}

The Charleston Gazette.

The Daily Athenaeum.

The Dominion Post.

The New York Times.

Chronicling America: Historic American Newspapers, Library of Congress. http://chroniclingamerica.loc.gov.

\section{Archival}

Prospectus of the Morgantown Building and Investment Company. Printed Ephemera. West Virginia and Regional History Center. West Virginia University, Morgantown, WV.

Bills, Scott Papers. West Virginia and Regional History Center. West Virginia University, Morgantown, WV.

Fleming, Delores Papers. West Virginia and Regional History Center, West Virginia University, Morgantown, WV.

Student Anti-War Movement. West Virginia and Regional History Center. West Virginia University, Morgantown, WV.

Woodford, W. Allen Papers. West Virginia and Regional History Center. West Virginia University, Morgantown, WV.

West Virginia University Office of Student Life Records, West Virginia and Regional History Center, West Virginia University, Morgantown, WV. 
Maps

Sanborn Map Company. Morgantown, Monongalia County, West Virginia: Oct. 1906. Scale 1:600 [50ft=1inch]. Sanborn Map Company. West Virginia and Regional History Collection.

Sanborn Map Company. Morgantown, Monongalia County, West Virginia: Nov. 1911. Scale 1:600 [50ft=1inch]. Sanborn Map Company. West Virginia and Regional History Collection.

Sanborn Map Company. Morgantown, Monongalia County, West Virginia: May 1921. Scale 1:600 [50ft=1inch]. Sanborn Map Company. West Virginia and Regional History Collection.

Sanborn Map Company. Morgantown, Monongalia County, West Virginia: Apr. 1927. Scale 1:600 [50ft=1inch]. Sanborn Map Company. West Virginia and Regional History Collection.

\section{Books}

Birnbach, Lisa. Lisa Birnbach's College Book. New York: Balletine Books, 1984.

Monticola. West Virginia University. http://www.eyearbook.com/West_Virginia_University_Monticola_Yearbook

Polk's Morgantown City Directory (Pittsburgh: R.L. Polk and Company, Publishers).

\section{Reports}

Briggs, Luke. West Virginia University Student Attitudes Toward Morgantown: A Survey of West Virginia University Sophomores and Seniors. Morgantown, WV: West Virginia University, 1974.

Campus Neighborhoods Revitalization Corporation. Proposed TIF Project for Sunnyside, Phase II, 2013-14. Morgantown, WV: Campus Neighborhoods Revitalization Corporation, June 2013. Accessed April 24, 2017, http://sunnysideupwv.org/images/CNRC-TIF_Project,_Phase_II_2013.pdf

Campus Neighborhoods Revitalization Corporation. From Mutt's Place to University Place. Annual Report 2013-2014. Morgantown, WV: Campus Neighborhoods Revitalization Corporation, Feb. 2014. Accessed April 24, 2017. http://sunnysideupwv.org/images/CNRC--2014_Annual_Report_July_10.pdf 
Campus Neighborhoods Revitalization Corporation. Annual Report 2015. Morgantown, WV: Campus Neighborhoods Revitalization Corporation, 2015. Accessed April 24, 2017. http://sunnysideupwv.org/images/page_001.pdf

Campus Neighborhoods Revitalization Corporation. Sunnyside TIF Property Database. Morgantown, WV: Campus Neighborhood Revitalization Corporation, 2015. Accessed April 24, 2017. http://sunnysideupwv.org/images/Sunnyside_TIF_Property_Databate.pdf

Environmental Planning and Design, LLC. Sunnyside Up: Comprehensive Revitalization Plan, Volume 1. Morgantown: Campus Neighborhoods Revitalization Corporation, Fall 2004.

Holter, F. J. Student Housing: West Virginia University. Report. Morgantown, WV: May 1960.

National Park Service, Department of the Interior. "Defining Landscape Terminology." Guidelines for the Treatment of Cultural Landscapes. Accessed April 5, 2017. https://www.nps.gov/tps/standards/four-treatments/landscapeguidelines/terminology.htm.

Pride, Cletis and David Drew. As Others See Us: Three Key Publics Assess West Virginia University; Final Report of a Study Conducted for the West Virginia University Foundation, Inc. Morgantown: West Virginia University, 1972.

Stewart, Irvin. West Virginia University: 1946-1958: A Report Covering the Administration of Irvin Stewart as President of the University, July 1, 1946-June 30, 1958. West Virginia University, Bulletin, Series 58, No. 12-2, June 1958.

Taylor \& Taylor Associates, Inc. Survey Report: Historic Resource Survey, First Ward, Morgantown, West Virginia. Presented to Morgantown Historic Landmarks Commission. DuBois, PA: Taylor \& Taylor Associates, Inc., Apr. 2010.

West Virginia University. WVU 2020: Strategic Plan for the Future. Morgantown: West Virginia University). Accessed April 24, 2017. http://strategicplan.wvu.edu/r/download/90223.

West Virginia University Facilities Planning. West Virginia University: Main Campus Student Housing Master Plan - 2012. Last updated September 28, 2012. Accessed April 23, 2017. http://facilitiesplanning.wvu.edu/files/d/25ad7fe5-b23c-432b-9f1b00b3cd531b12/student-housing-mater-plan-2012.pdf.

West Virginia University Facilities Planning. West Virginia University: Ten-Year Campus Master Plan. 2012. Accessed April 23, 2016. http://facilitiesplanning.wvu.edu/files/d/a3d8ebd1-edc5-4a3a-9dc2e3fcadfb1cd7/campus-master-plan-2012.pdf 


\section{Monographs}

Barnett, Bob. Hillside Fields: A History of Sports in West Virginia. Morgantown: West Virginia University Press, 2013.

Bluestone, Barry and Bennett Harrison. The Deindustrialization of America: Plant Closings, Community Abandonment, and the Dismantling of Basic Industry. New York: Basic Books, 1982.

Callahan, James Morton. History of the Making of Morgantown, West Virginia: A Type Study in Trans-Appalachian Local History. Morgantown: Morgantown Printing and Binding Company, 1926.

Core, Earl L. The Monongalia Story: A Bicentennial History IV. Industrialization. Parsons, West Virginia: McClain Printing, 1982.

Core, Earl L. The Monongalia Story: A Bicentennial History V. Sophistication. Parsons, West Virginia: McClain Printing, 1984.

Cowie, Jefferson and Joseph Heathcott. Beyond the Ruins: The Meanings of Deindustrialization. Ithaca: Ilr Press Books, Cornell University Press, 2003.

Curry, Timothy Jon, Kent Schwirian, and Rachael A. Woldoff. High Stakes: Big Time Sports and Downtown Redevelopment. Columbus: The Ohio State University Press, 2004.

Doherty, William T., Jr. and Festus P. Summers. West Virginia University: Symbol of Unity in a Sectionalized State. Morgantown: West Virginia University Press, 1982.

Faehmel, Babette. College Women in the Nuclear Age: Cultural Literacy and Female Identity, 1940-1960. New Brunswick, NJ: Rutgers University Press, 2012.

Fones-Wolf, Ken. Glass Towns: Industry, Labor and Political Economy in Appalachia, 18901930s. Urbana: University of Illinois Press, 2007.

Gumprecht, Blake. The American College Town. Amherst, MA: University of Massachusetts Press, 2008.

Hayden, Dolores. The Power of Place: Urban Landscapes as Public History. Cambridge: The MIT Press, 1997.

Hoekema, David A. Campus Rules and Moral Community: In Place of in Loco Parentis. Lanham, Md.: Rowman \& Littlefield, 1994.

Horowitz, Helen Lefkowitz. Campus Life: Undergraduate Cultures from the End of the Eighteenth Century to the Present. Chicago: The University of Chicago Press, 1987. 
Isenberg, Alison. Downtown America: A History of the Place and the People Who Made It. Chicago: University of Chicago Press, 2004.

Jacobs, Jane. The Death and Life of Great American Cities. New York: Random House, 1961.

Jakle, John. A and David Wilson, Derelict Landscapes: The Wasting of America's Built Environment. Savage, MD: Rowman and Littlefield, 1992.

Kyvig, David E. and Myron A. Marty. Nearby History: Exploring the Past Around You. 3rd Edition. Lanham: AltaMira Press, 2010.

Lewis, Ronald L. Aspiring to Greatness: West Virginia University Since World War II. Morgantown: West Virginia University Press, 2013.

Longstreth, Richard, ed. Cultural Landscapes: Balancing Nature and Heritage in Preservation Practice. Minneapolis: University of Minnesota Press, 2008.

Melosi, Martin V. and Philip Scarpino, ed. Public History and the Environment. Malabar, FL: Krieger Publishing Company, 2004.

Rice, Otis K. and Stephen W. Brown. West Virginia: A History. Second edition. Lexington: University of Kentucky, 1993.

Shaw, Christopher and Malcom Chase, The Imagined Past: History and Nostalgia. Manchester: University of Manchester Press, 1989.

Schlereth, Thomas J. Victorian America: Transformations in Everyday Life, 1876-1915. New York: HarperCollins Publishers, 1991.

Solomon, Barbara Miller. In the Company of Educated Women: A History of Women and Higher Education in America. New Haven: Yale University Press, 1985.

Sloan, John J. III and Bonnie S. Fisher. The Dark Side of the Ivory Tower: Campus Crime as a Social Problem. Cambridge: Cambridge University Press, 2011.

Syrett, Nicholas L. The Company He Keeps: A History of White College Fraternities. Chapel Hill: University of North Carolina Press, 2009.

Thelin, John R. A History of American Higher Education. Baltimore: Johns Hopkins University Press, 2004.

Wechsler, Harry and Bernice Wuethrich. Dying to Drink: Confronting Binge Drinking on College Campuses. Rodale, 2002.

Weiss, Karen G. Party School: Crime, Campus, and Community. Boston: Northeastern University Press, 2013. 
West Virginia University Public History Option. Morgantown: A Bicentennial History. Morgantown Historical Society, 1985.

\section{Articles}

Boulware, Jenny and Andrew Mach, ed. "Glass Blowing and Community Building: A History of Morgantown, West Virginia's Sunnyside Neighborhood, 1890-2013.” West Virginia History Vol. 9, No. 1 (Spring 2015): 65-88.

Bromley, Ray. "On and Off Campus: Colleges and Universities and Local Stakeholders." Planning, Practice \& Research Vol. 21, No. 1 (February 2006): 1-24.

Drobney, Jeffrey A. "Generation in Revolt: Student Dissent and Political Repression at West Virginia University." West Virginia History Vol. 54 (1995): 105-122, http://www.wvculture.org/history/journal_wvh/wvh54-6.html.

Davalos, Sergio, et al. “"The good old days': An Examination of Nostalgia in Facebook Posts." International Journal Of Human-Computer Studies Vol. 83 (November 2015): 83-93.

Hathaway, Rosemary V. "From Hillbilly to Frontiersman: The Changing Nature of the WVU Mountaineer." West Virginia History Vol. 8, No. 2 (Fall 2014): 15-45.

Hurley, Andrew. "Narrating the Urban Waterfront: The Role of Public History in Community Revitalization." The Public Historian Vol 28, No. 4 (Fall 2006): 19-50.

Kiendl, Arthur H. "Academic Round Table: In Loco Parentis," The Journal of Higher Education Vol. 34, No. 8 (1963): 465.

Lafer, Gordon. "Land and Labor in the Post-Industrial University Town: Remaking Social Geography." Political Geography Vol. 22 (2003): 89-117.

Pickren, Graham. "Where Can I Build My Student Housing? The Politics of Studentification in Athens-Clarke County, Georgia." Southeastern Geographer. Vol. 52 No. 2 (Summer 2012): 113-130.

Shircliffe, Barbara. "WWe Got the Best of That World': A Case for the Study of Nostalgia in the Oral History of School Segregation.” The Oral History Review Vol. 28, No. 2 (SummerAutumn 2001): 59-84.

Tan, Andy Soon Leong. "Through the Drinking Glass: An Analysis of the Cultural Meanings of College Drinking.” Journal of Youth Studies Vol. 15, No. 1 (February 2012): 119-142.

Yanni, Carla "Campus History at the Crossroads: Three Divergent Methods." Journal of Planning History Vol 11, No. 4 (2012): 349-351. 


\section{Theses and Dissertations}

Annie, Frank Harrison. "Normalization of Neighborhood Disorder in a College Town: Now Students Making Sense of their Community." MA Thesis, West Virginia University. Morgantown, 2013.

Keeney, C. Belmont. "Soldiers and Stereotypes: Mountaineers, Cultural Identity, and World War II.” PhD Dissertation, West Virginia University, 2009.

Weiner, Robert Stanley. "The Location and Distribution of the Glass Industry of Ohio, Pennsylvania, and West Virginia.” MA thesis, University of Pittsburgh, 1949.

\section{Websites and Online Publications}

Cook, Will and Tom Mayes, "Shifting the Paradigm from Demolition to Reuse: New Tools," Preservation Leadership Forum. National Trust for Historic Preservation. February 16, 2017. Accessed March 29, 2017. http://forum.savingplaces.org/blogs/specialcontributor/2017/02/16/shifting-the-paradigm-from-demolition-to-reuse-new-tools.

Grasgreen, Allie. "Party School." Interview with Karen Weiss. December 3, 2013. Accessed March 25, 2017. https://www.insidehighered.com/news/2013/12/03/book-detailscampus-and-community-consequences-party-school-culture.

Griffith, Katie. “The \$250,000 Question,” Morgantown Magazine, April 7, 2015, accessed April 24, 2017, http://www.morgantownmag.com/morgantown/April-May-2015/The-250000Question/index.php?cparticle $=1 \&$ siarticle $=0 \#$ artanc.

Kasey, Pam. "Sunnyside Up.” Morgantown Magazine. May 12, 2016. Accessed April 24, 2017, http://www.morgantownmag.com/morgantown/April-May-2016/Sunnyside-Up/.

Magnusson, Sigurdur Gylfi. “What is Microhistory?” History News Network. May 7, 2006. Accessed March 26, 2017. http://historynewsnetwork.org/article/23720.

Ray, Leann. Inspecting Sunnyside. Blog. Last modified June 15, 2012. https://inspectingsunnyside.wordpress.com.

Rypkema, Donovan. "Sustainability and Historic Preservation.” Economic Benefits of Preservation. Preservation Action Council of San Jose. March 10, 2007. Accessed March 29, 2017. http://www.preservation.org/rypkema.htm.

Remembering Sunnyside WVU. Facebook.com. Last modified April 27, 2017. https://www.facebook.com/sunnysidewvu/?fref=ts.

University Relations/News. "WVU engages in public-private partnership to develop a \$70 million mixed use residential and retail complex in Sunnyside." WVU Today. Oct. 26, 
2012. http://wvutoday.wvu.edu/n/2012/10/26/wvu-engages-in-public-private-partnershipto-develop-a-70-million-mixed-use-residential-and-retail-complex-in-sunnyside.

University Relations/News. "A university on the rise: Gee shares 'big ideas' for WVU, its partners." WVU Today. October 6, 2014. Accessed April 24, 2017. http://wvutodayarchive.wvu.edu/n/2014/10/06/a-university-on-the-rise-gee-shares-big-ideas-for-wvu-itspartners.html.

University Place. “Amenities," University Place. West Virginia University. Last modified April 26, 2016. Accessed April 27, 2017. http://uplace.wvu.edu/amenities.

University Place at Sunnyside. Facebook.com. July 8, 2014. Accessed April 27, 2017, https://www.facebook.com/UniversityPlaceAtSunnyside/photos/a.319931111483167.107 $3741829.291234244352854 / 435075613302049 /$ ?type $=3 \&$ theater.

Wolfman-Arent, Avi. “'We're No. 2!' And Other Ways to Respond to 'Party School' Fallout," The Chronicle of Higher Education, August 6, 2014. Accessed April 24, 2017.

http://www.chronicle.com/blogs/ticker/were-number-2-and-other-ways-to-respond-toparty-school-fallout/83409. 


\section{APPENDIX}

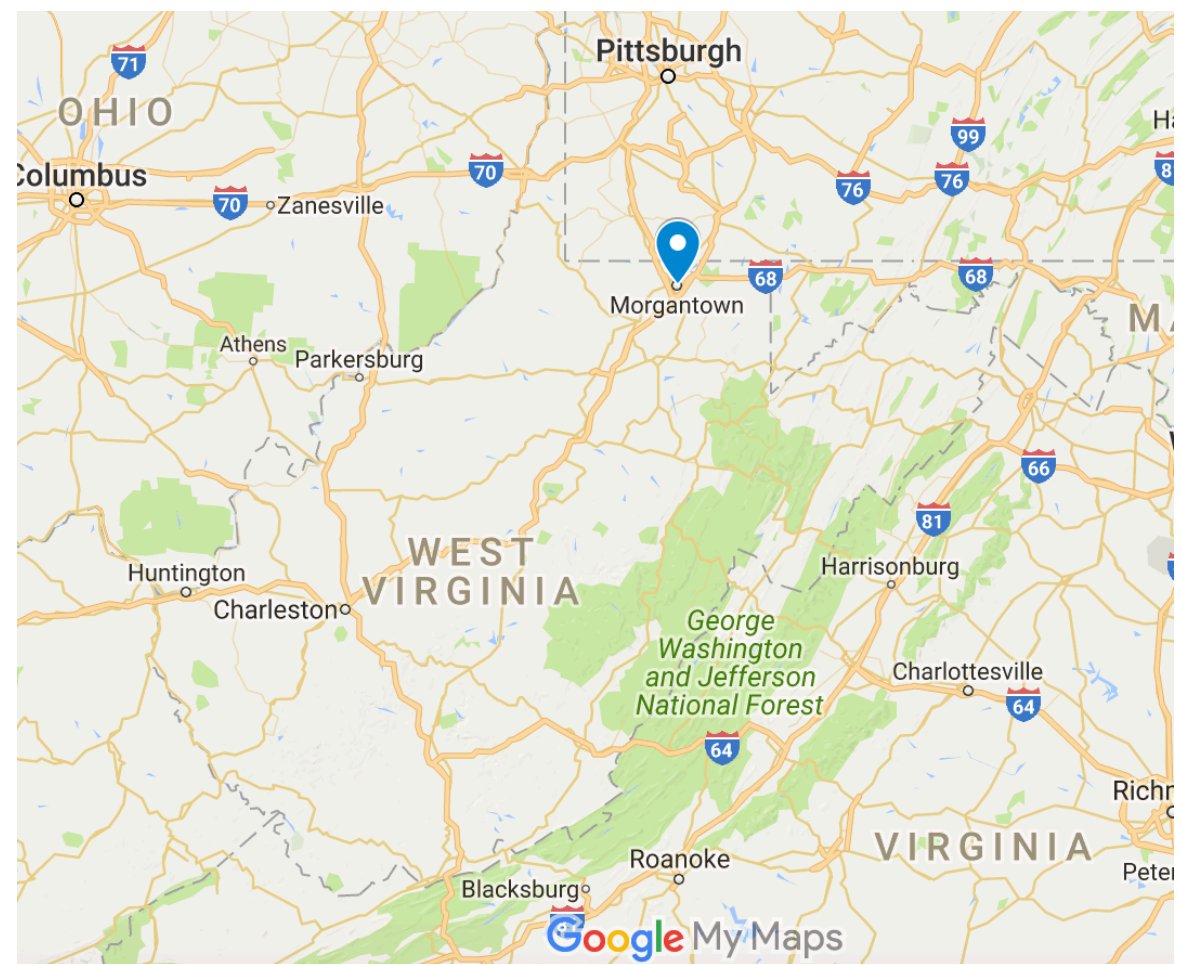

Curtin, Pamela. Map of Morgantown and Sunnyside. 2016. Map. Google My Maps.

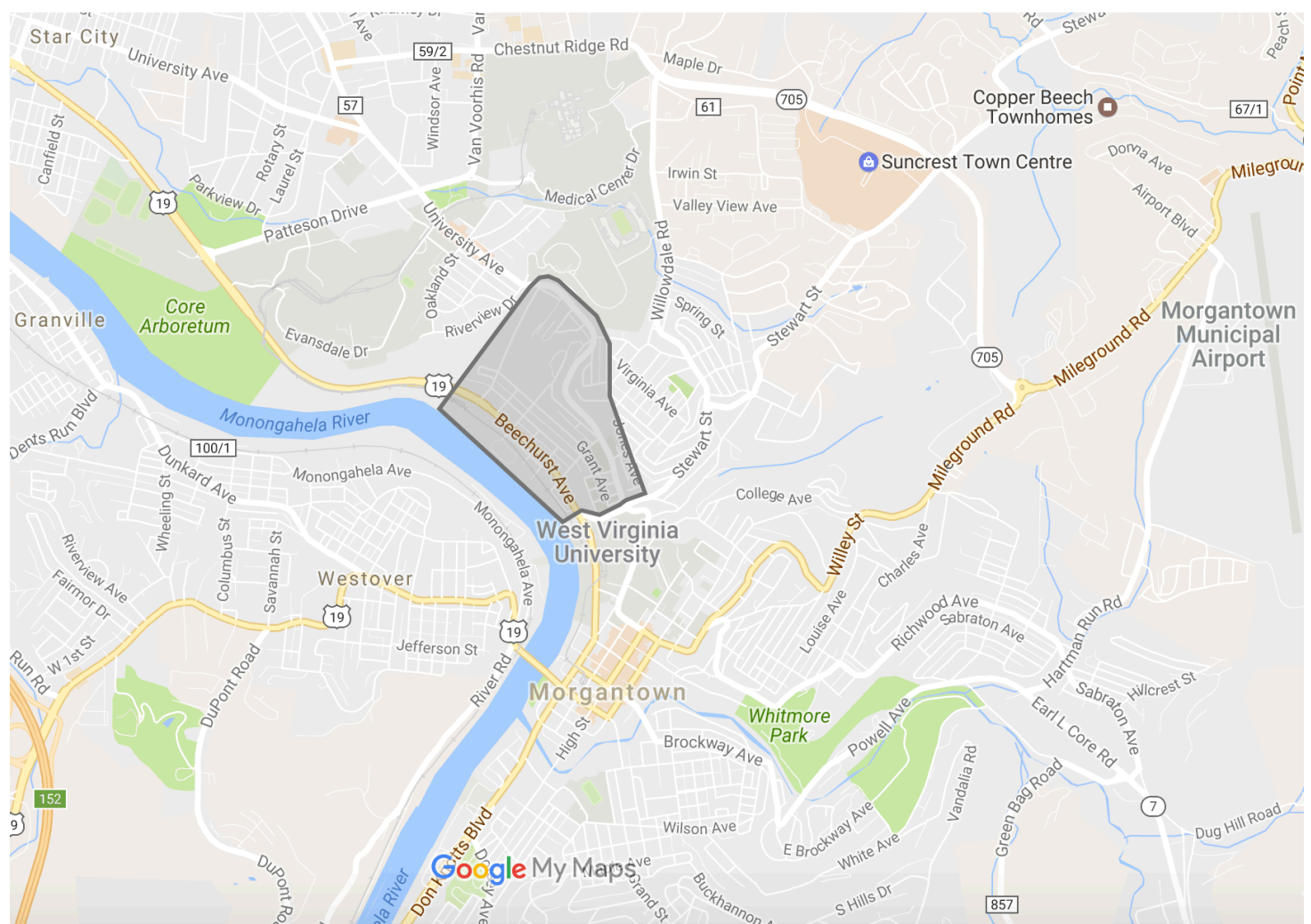

Curtin, Pamela. Map of Morgantown and Sunnyside. 2016. Map. Google My Maps. 


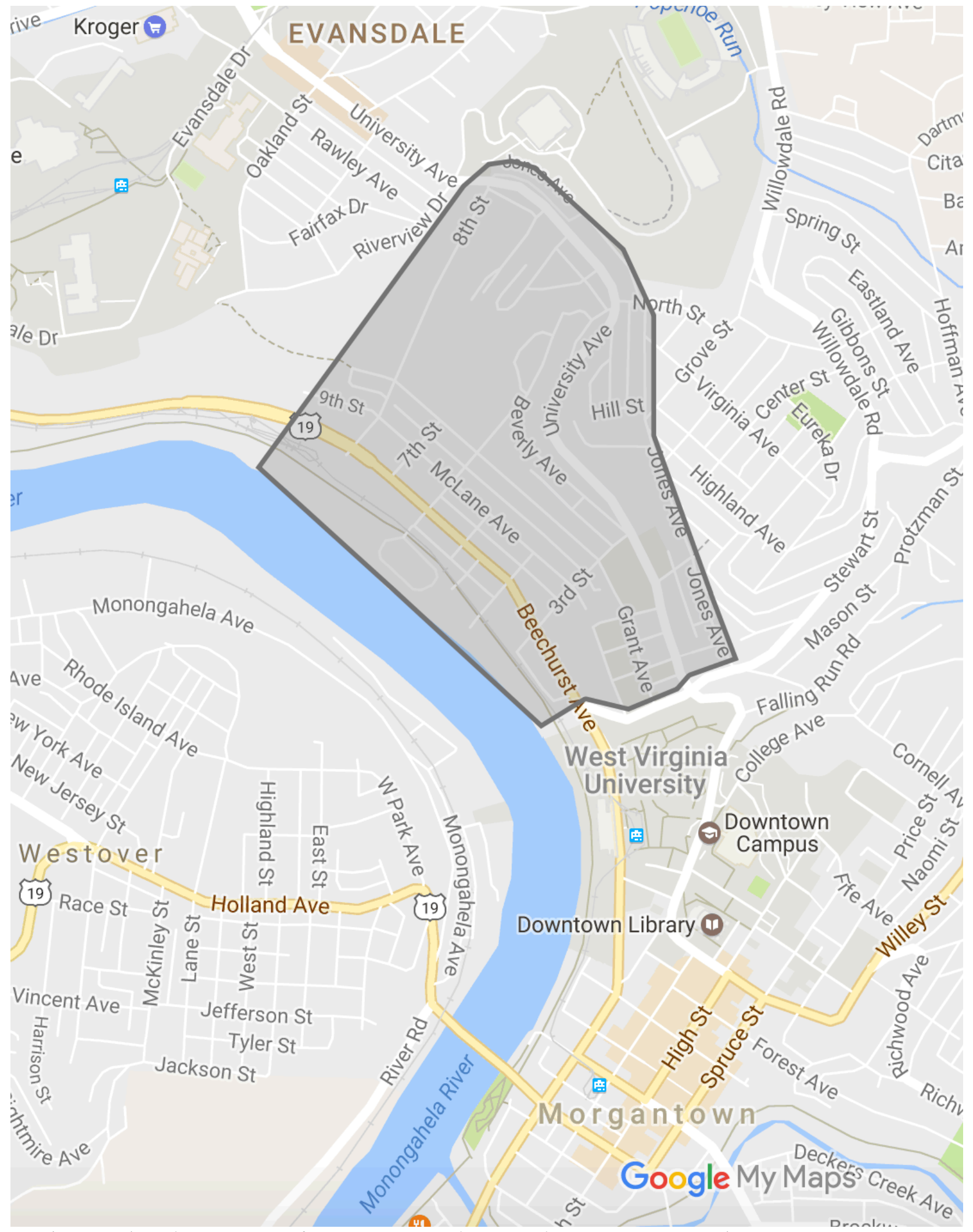

Curtin, Pamela. Close-up map of Morgantown and Sunnyside. 2016. Map. Google My Maps. 


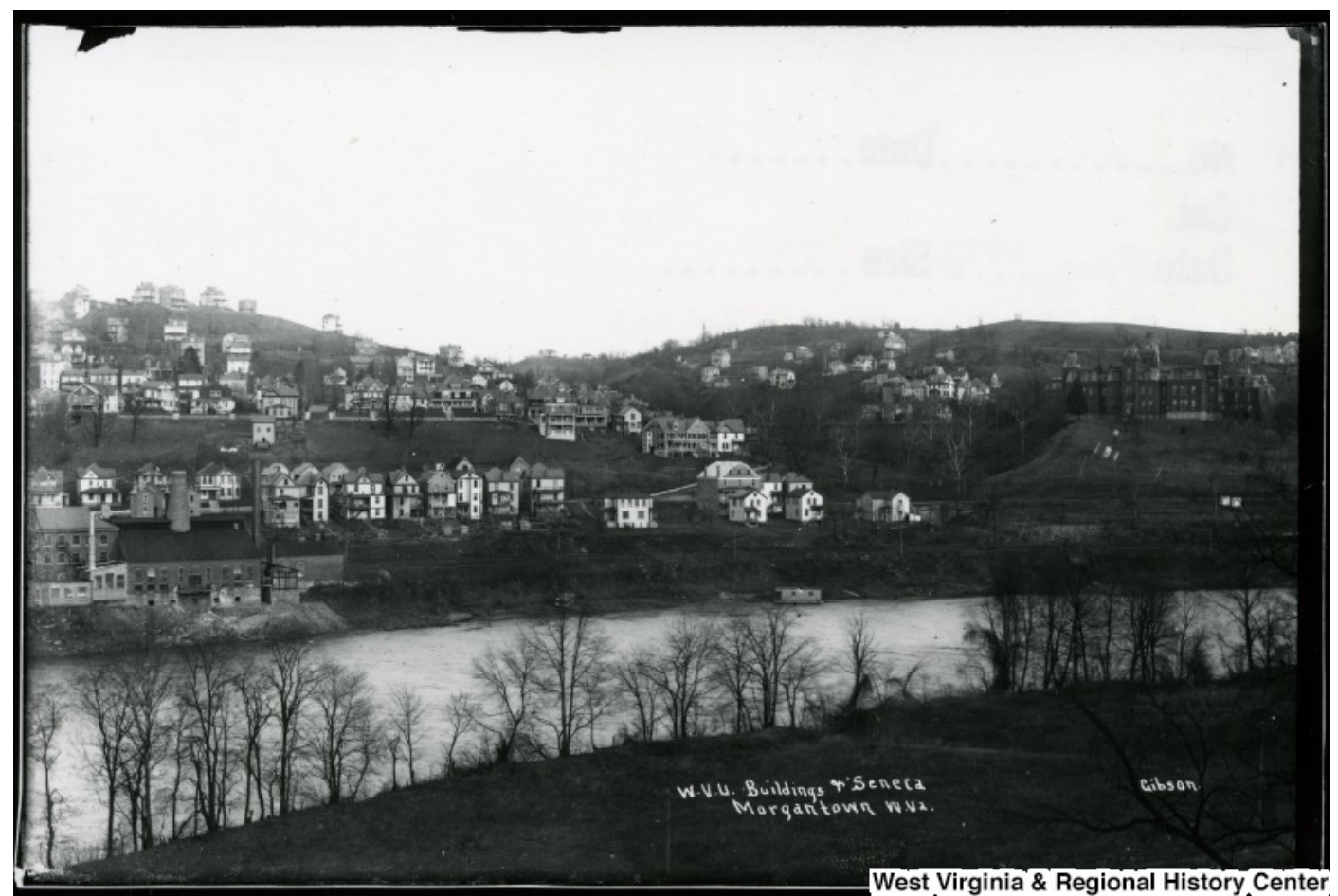

"View of West Virginia University and Seneca, Morgantown, W. Va." ca. 1912. Print. West Virginia and Regional History Center. West Virginia University Libraries. Morgantown, WV. Accessed April 2017. http://wvhistoryonview.org/catalog/wvulibraries:11869

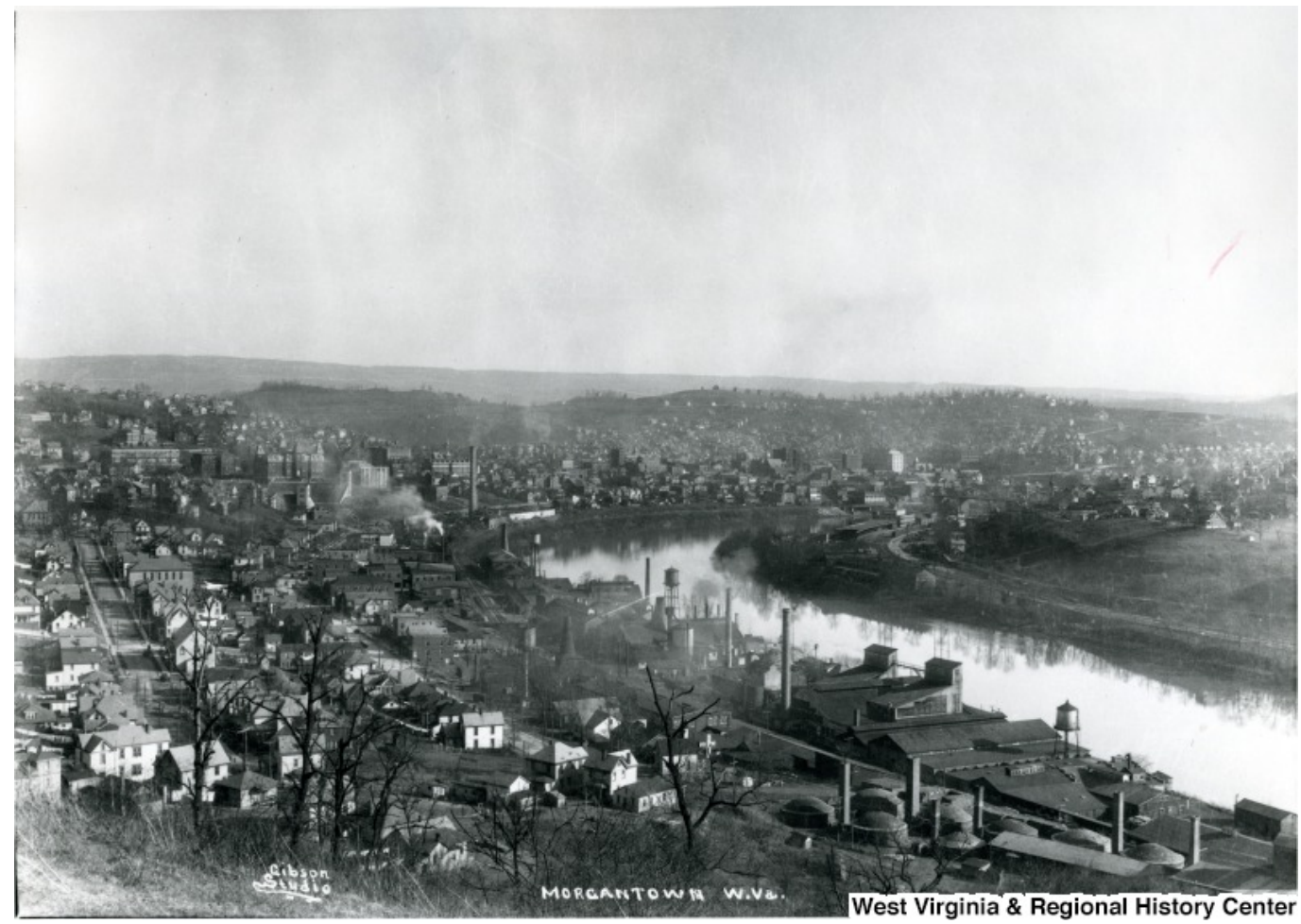

"Seneca Addition, Morgantown, W. Va." ca. 1925. Print. West Virginia and Regional History Center. West Virginia University Libraries. Morgantown, WV. Accessed April 2017. http://wvhistoryonview.org/catalog/wvulibraries:19031 


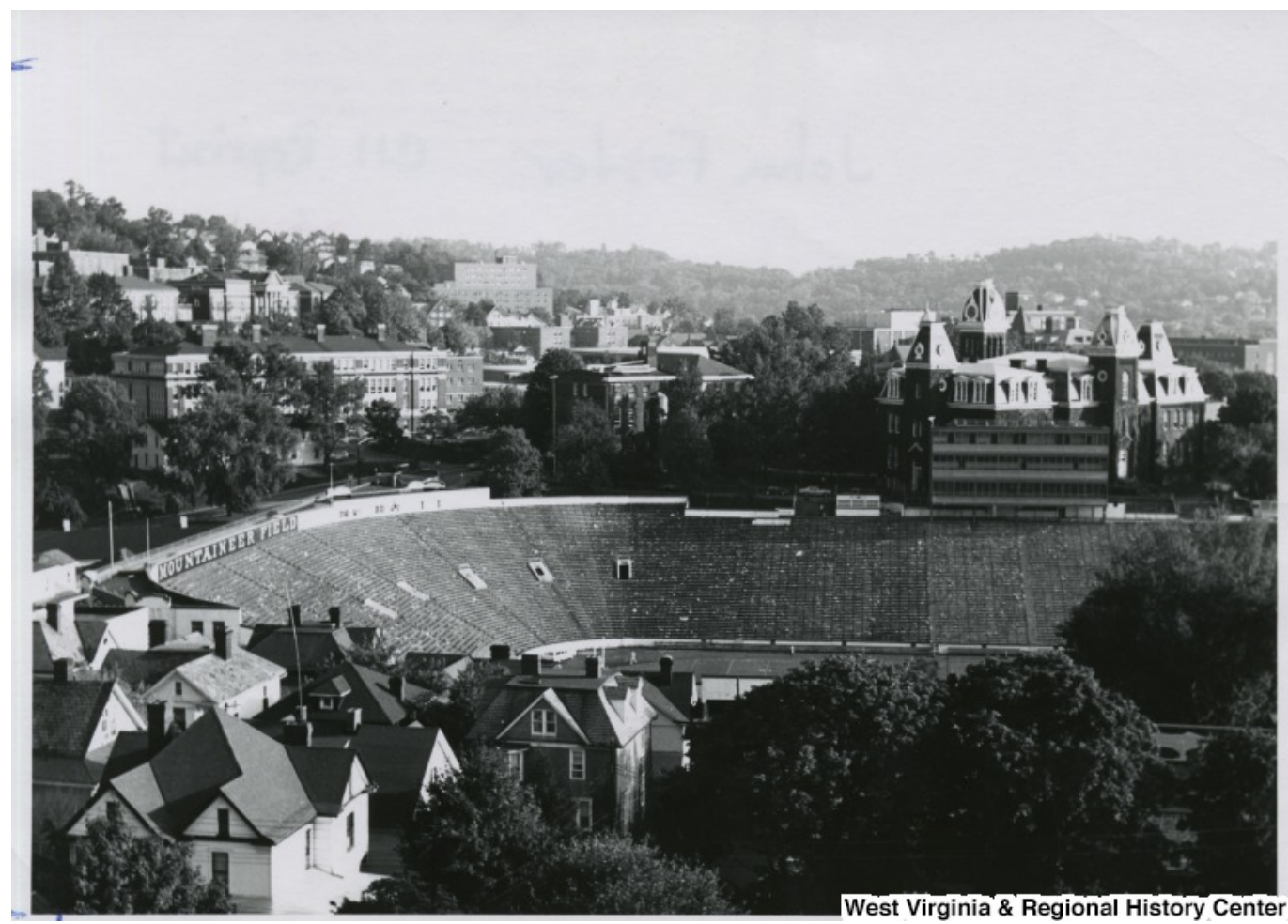

"Mountaineer Field Viewed from Sunnyside, West Virginia University." ca. 1967. Print. West Virginia and Regional History Center. West Virginia University Libraries. Morgantown, WV. Accessed April 2017.

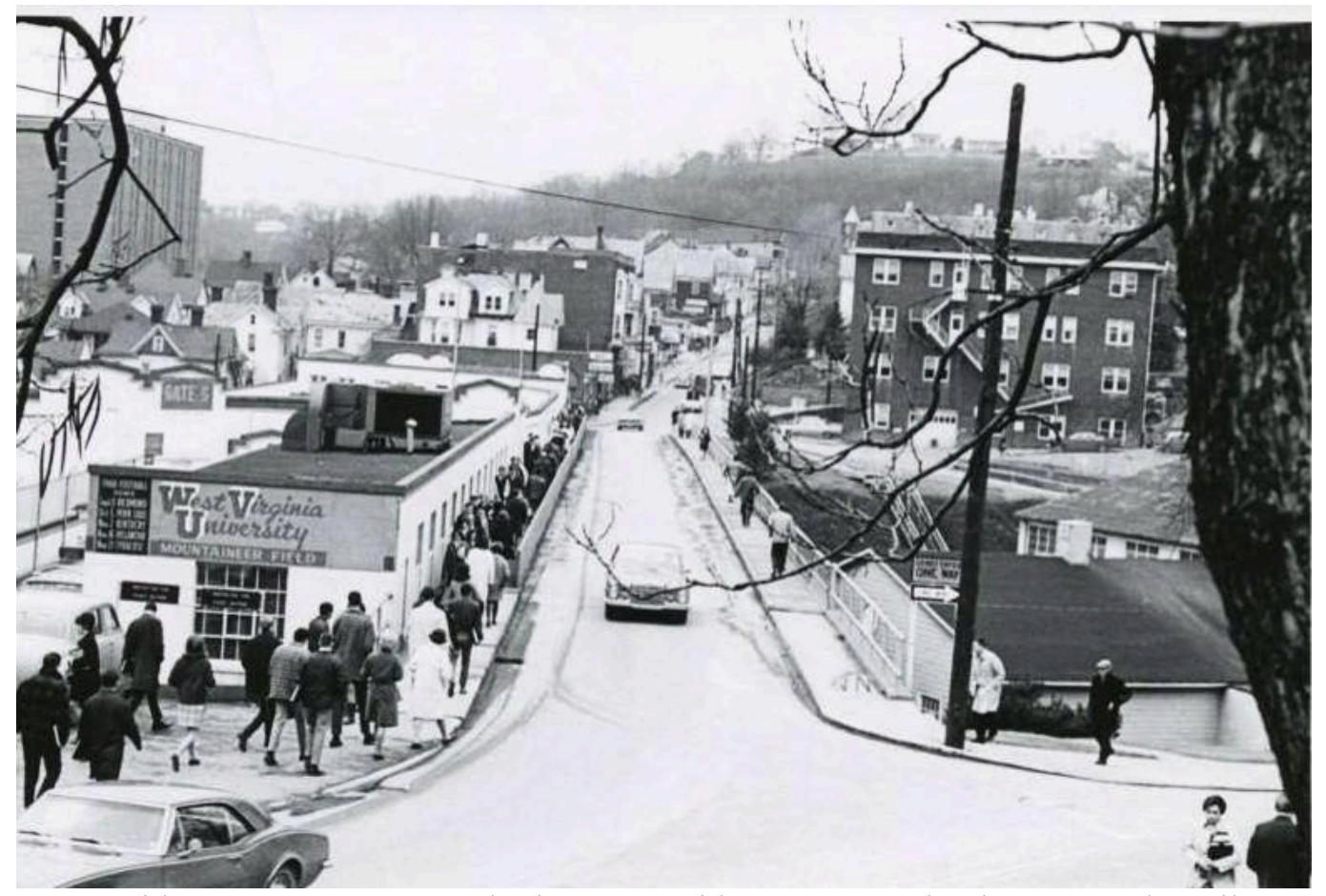

“Sunnyside." ca. 1960s. Remembering Sunnyside WVU, Facebook. Accessed April 2017. https://www.facebook.com/sunnysidewvu/photos/pb.434528833334572.$2207520000.1462054921 . / 858331164287668 /$ ?type $=3 \&$ theater 
Views of the 2100 block of Sunnyside

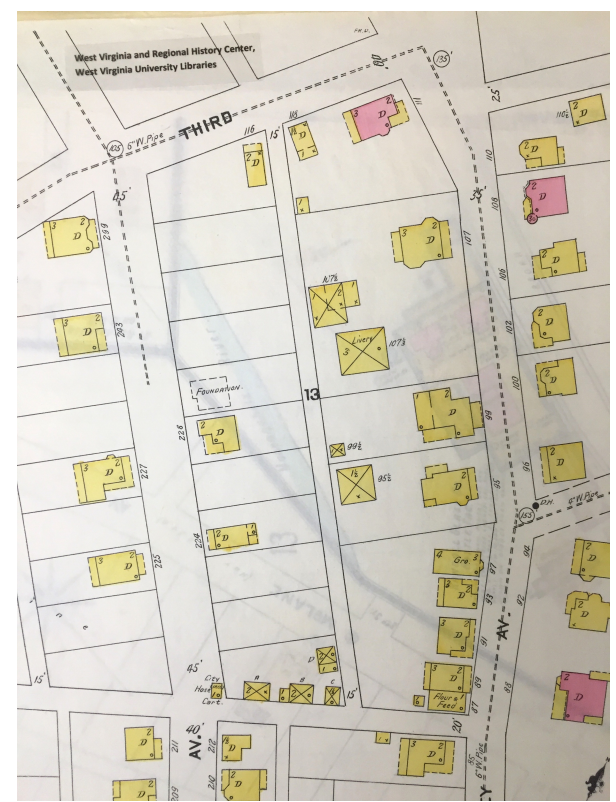

Sanborn Fire Insurance Maps. Morgantown, Monongalia County, West Virginia: Oct. 1906. Sanborn, Western Factory, 18991927, A\&M 1307, West Virginia and Regional History Center. West Virginia University Libraries. Morgantown WV.

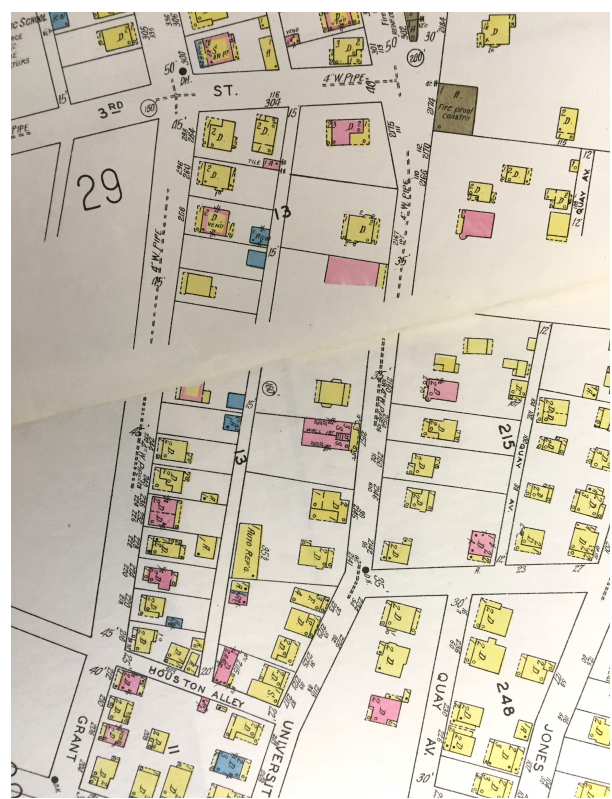

Sanborn Fire Insurance Maps. Morgantown, Monongalia County, West Virginia: Apr. 1927. Sanborn, Western Factory, 18991927, A\&M 1307, West Virginia and Regional History Center. West Virginia University Libraries. Morgantown WV.
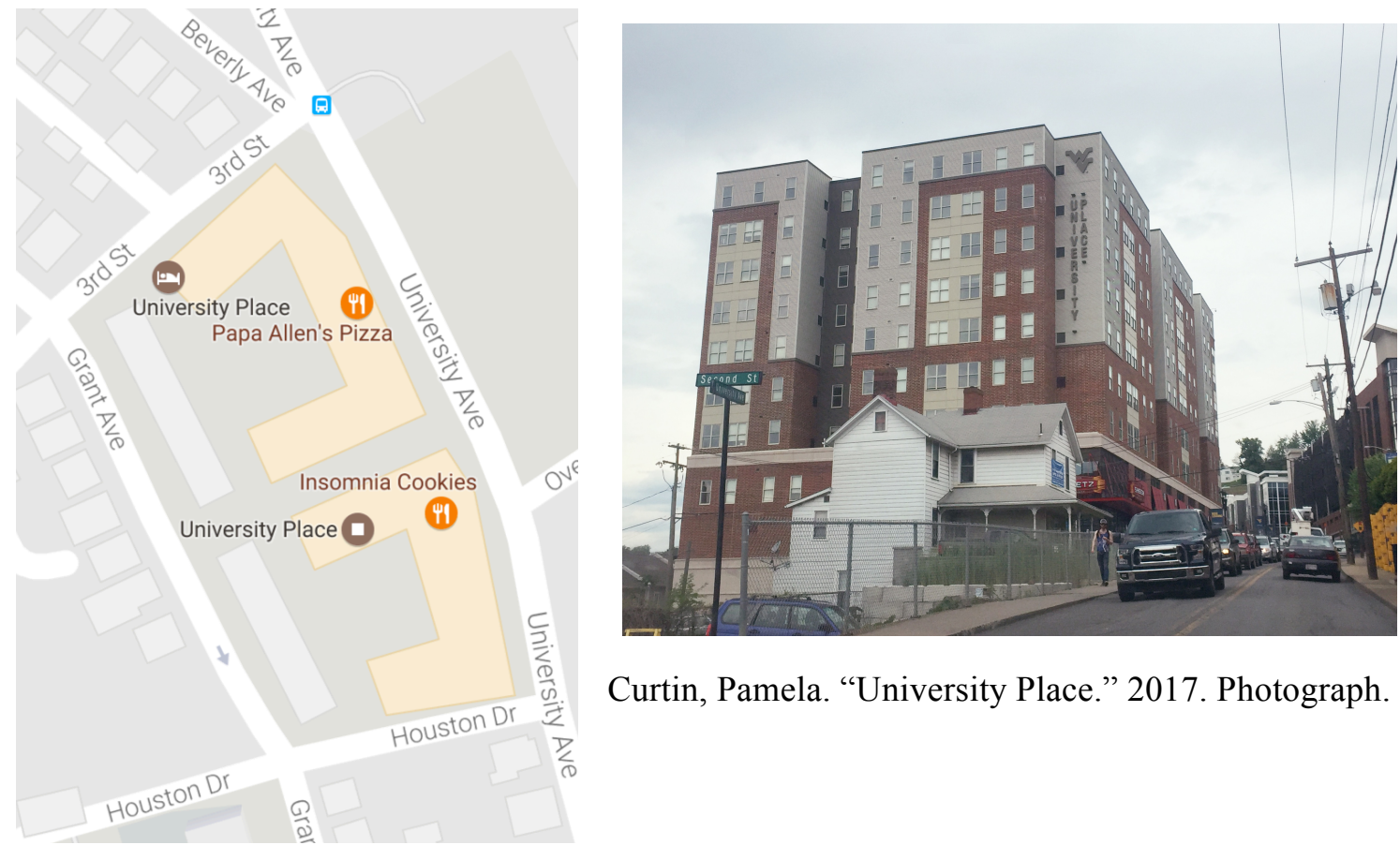

Curtin, Pamela. "University Place.” 2017. Photograph.

Google. Map of 2100 block of Sunnyside. 2017. Map.

Google Maps. Accessed April 25, 2017. 


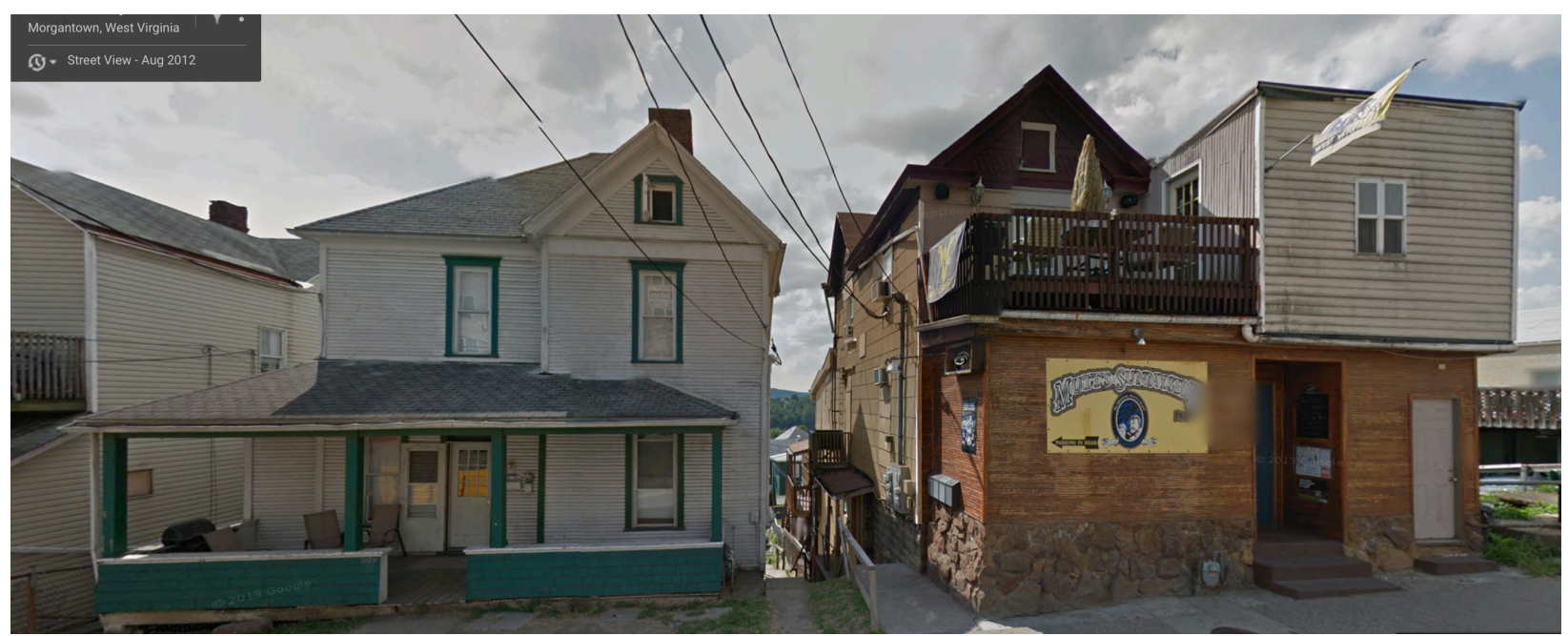

Google. 2125 and 2129 University Avenue, Sunnyside, Morgantown, West Virginia. Google Street View. Google Maps. August 2012. Accessed April 25, 2017.

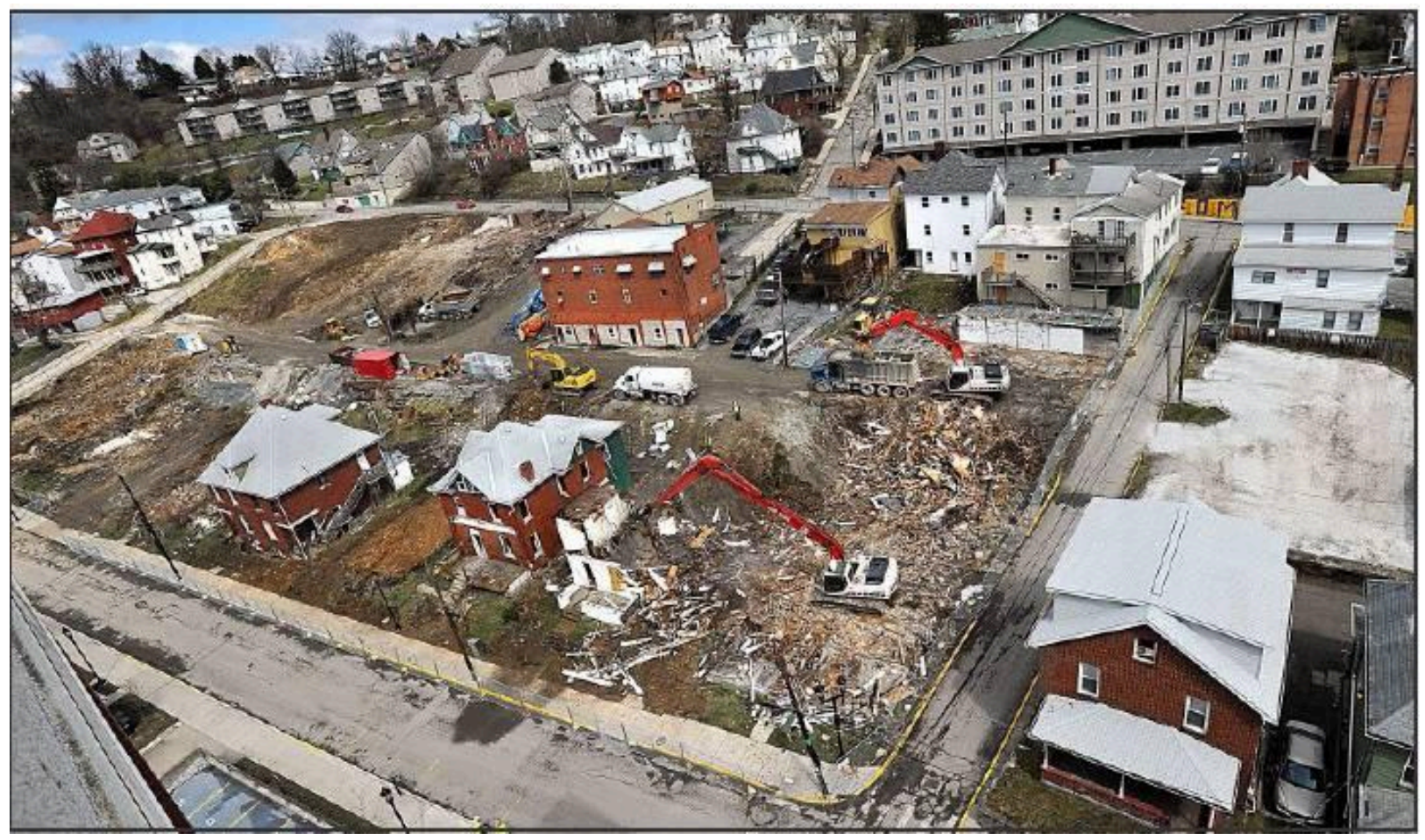

"Sunnyside Demolition." 2013. Aull Center for Local History and Genealogical Research. Morgantown Public Library System. 


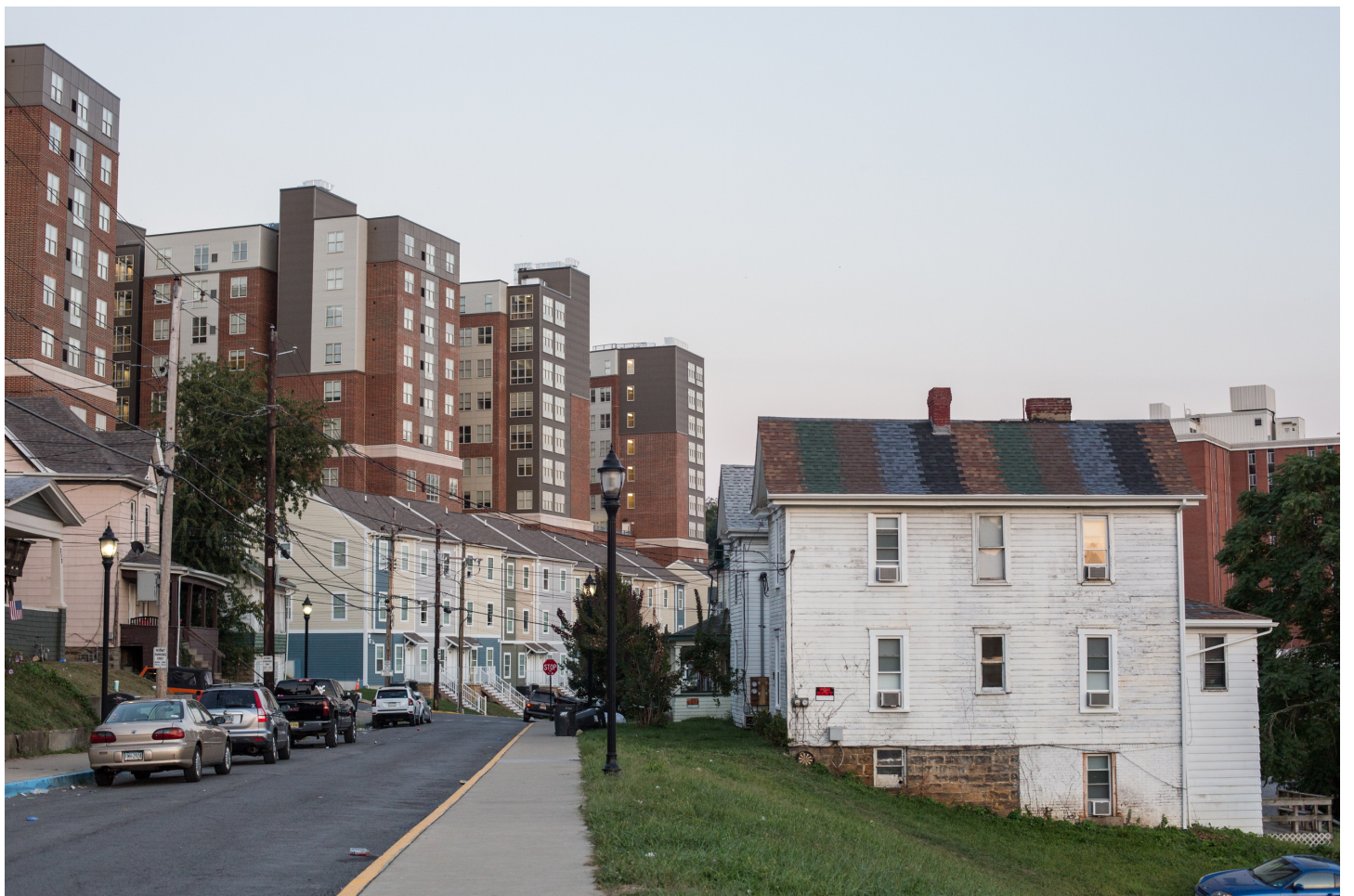

Curtin, Pamela. "Sunnyside, old and new. Grant Avenue with University Place in background." 2016. Photograph.

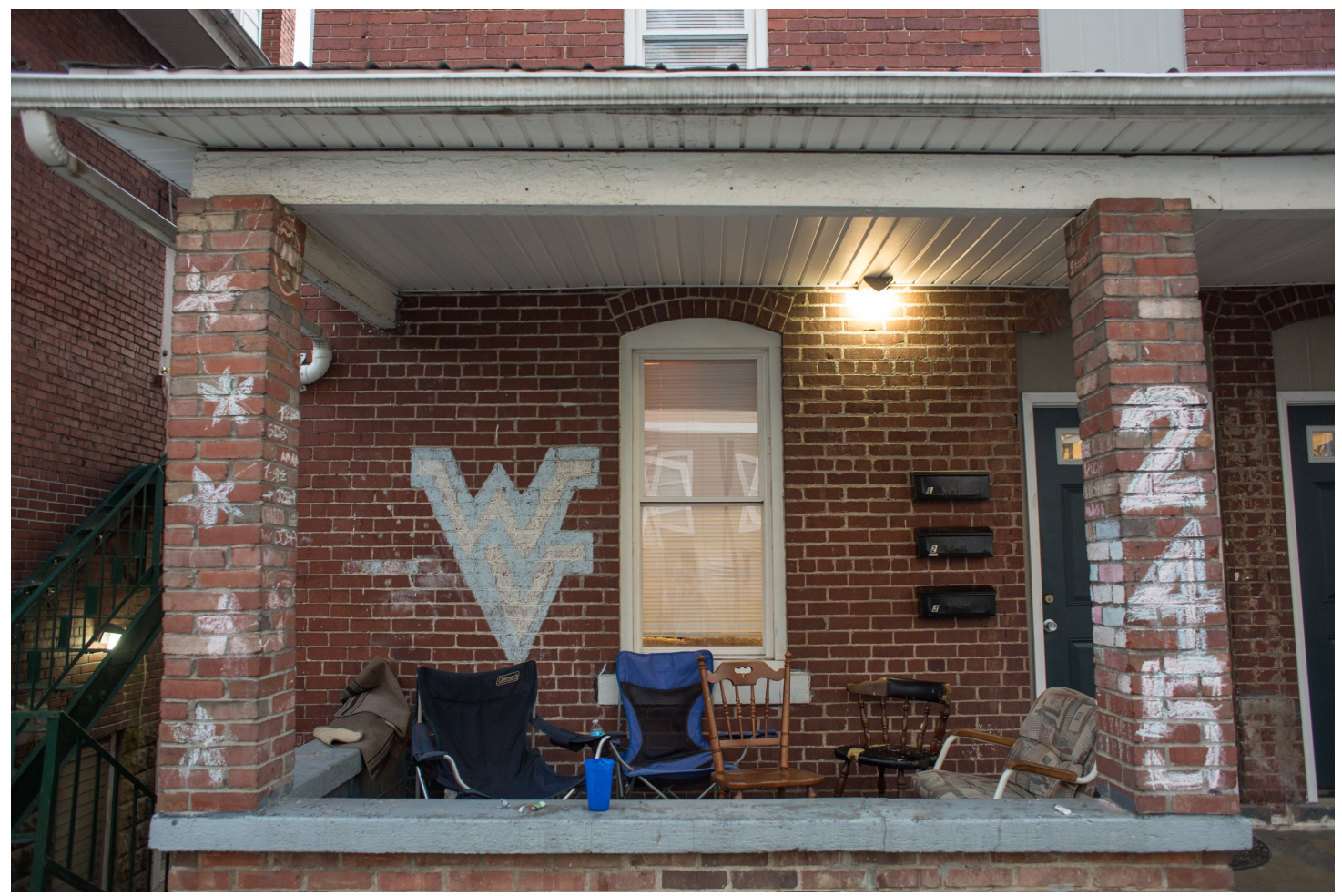

Curtin, Pamela. "Students making their mark on Sunnyside." 2016. Photograph. 


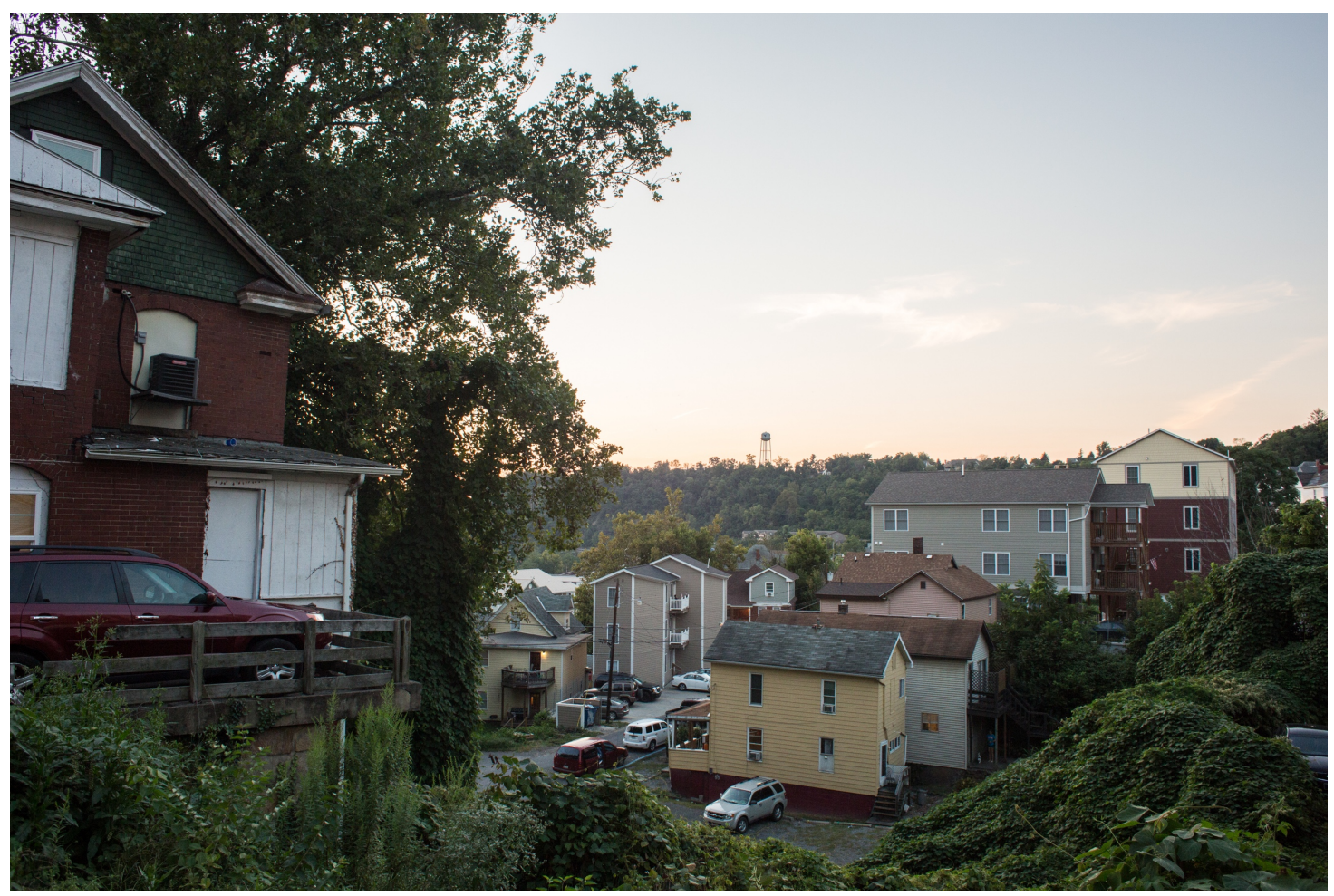

Curtin, Pamela. "Sunnyside landscape." 2016. Photograph.

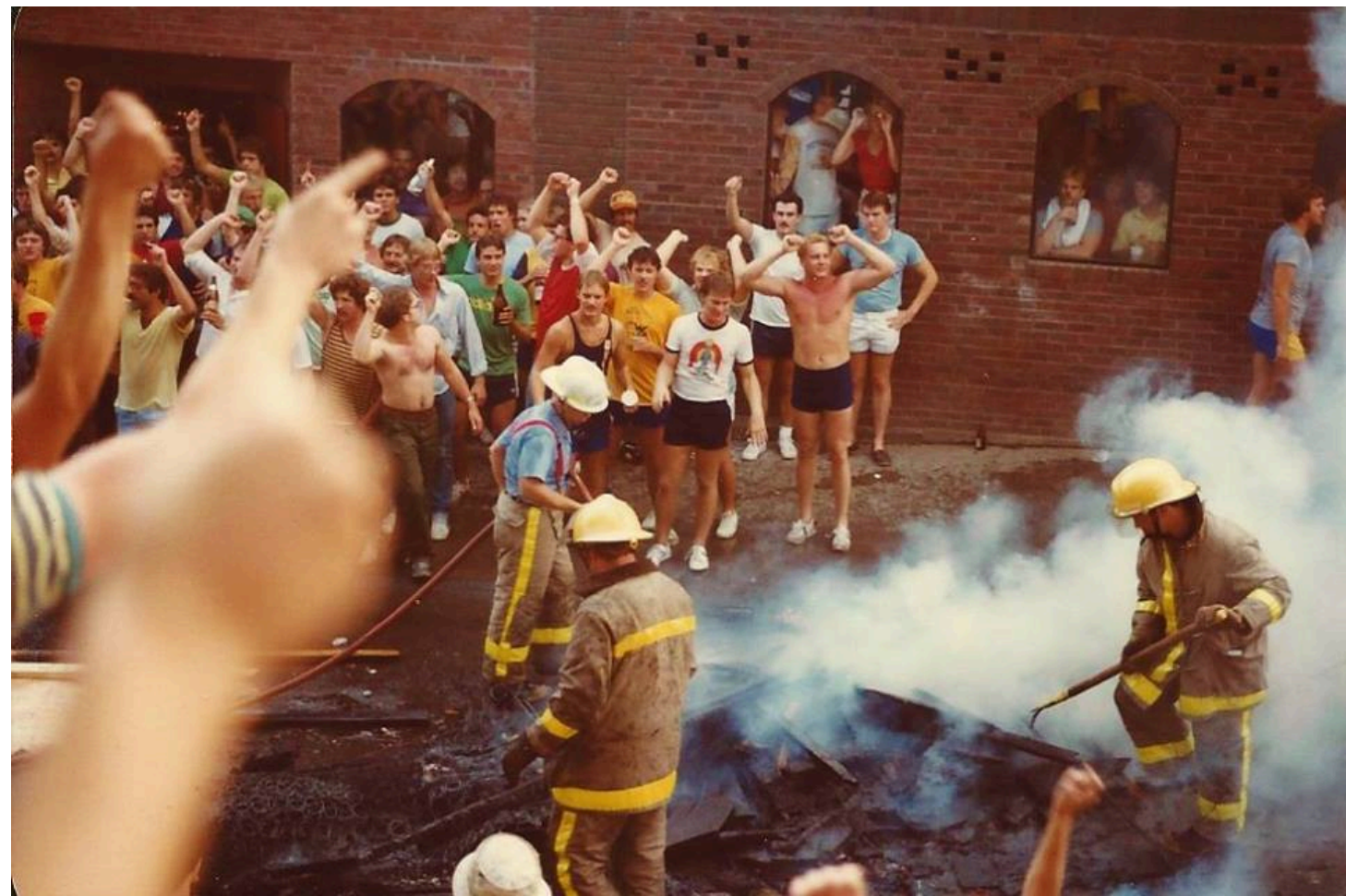

"Couch burning, 1982 Oklahoma away win." 1982. Photograph. Remembering Sunnyside WVU, Facebook. Accessed April 26, 2017.

https://www.facebook.com/sunnysidewvu/photos/pcb.1155077184613063/1155075051279943/?t ype $=3 \&$ theater 